Arkadiusz Górnisiewicz and Bogdan Szlachta (Eds.)

The Concept of Constitution in the History of Political Thought 

Arkadiusz Górnisiewicz and Bogdan Szlachta (Eds.)

\section{The Concept of Constitution in the History of Political Thought}

Managing Editor: Katarzyna Michalak

Associate Editor: Arkadiusz Górnisiewicz

Language Editor: Mark C. Anderson 
ISBN 978-3-11-058191-1

e-ISBN 978-3-11-058192-8

\section{(cc) BY-NC-ND}

This work is licensed under the Creative Commons Attribution-NonCommercial-NoDerivs 3.0 License.

For details go to http://creativecommons.org/licenses/by-nc-nd/3.0/.

(C) 2017 Arkadiusz Górnisiewicz, Bogdan Szlachta and chapter`s contributors.

Published by De Gruyter Open Ltd, Warsaw/Berlin

Part of Walter de Gruyter GmbH, Berlin/Boston

The book is published with open access at www.degruyter.com.

Library of Congress Cataloging-in-Publication Data

A CIP catalog record for this book has been applied for at the Library of Congress.

Managing Editor: Katarzyna Michalak

Associate Editor: Arkadiusz Górnisiewicz

Language Editor: Mark C. Anderson

www.degruyteropen.com

Cover illustration: (C) 2017 4FR, gettyimages 


\section{Contents}

Editors' Note and Acknowledgments — IX

Bogdan Szlachta

1 The Ambiguity of Constitutionalism - 1

Bibliography 12

Paweł Kaczorowski

2 Epistemology of Constitution - 14

$2.1 \quad$ Part One - 14

$2.2 \quad$ Part Two -19

$2.3 \quad$ Conclusion -28

Bibliography 29

Alvydas Jokubaitis

3 Can the Constitution Do Away with Nation State? - 32

3.1 The Phenomenon of Central and Eastern Europe - 33

3.2 The Nature of the Nation State - 36

3.3 The Conflict between Nation and Constitution - 39

Bibliography 44

Waldemar A. Skrobacki

$4 \quad$ Remarks on the Legal and the Practical:

The Rechtsstaat in Europe's Development of the Rule of Law -45

Bibliography -60

Dorota Pietrzyk-Reeves

5 Magna Carta and the Rise of Anglo-American Constitutionalism - 63

$5.1 \quad$ The Great Charter — 63

5.2 Magna Carta as a Model in Medieval and Early-Modern Europe — 66

5.3 Magna Carta in America - 71

5.4 Conclusion $-\mathbf{7 2}$

Bibliography 73 
Kazimierz Michat Ujazdowski

6 The Case of France: Vitality of the Republican Legal Tradition - 75

6.1 Idea of the Sovereignty of the Nation and Its Ramifications -76

6.2 Statism and Centralism - $\mathbf{8 0}$

6.3 Opposition to the Rule of Judges — 82

6.4 The Fifth Republic - Institutional Revolution within the Framework of Republican Tradition $-\mathbf{8 4}$

$6.5 \quad$ Conclusions -85

Bibliography -86

Ferenc Hörcher

7 Is the Historical Constitution of Hungary Still a Living Tradition? A Proposal for Reinterpretation - 89

7.1 The Historical Constitution of Hungary: A Diffuse Concept — 89

7.2 Political Thought, Constitutional Culture and the "Philosophy" of the Constitution — 91

7.3 Historical Layers of Constitutional Life in Hungary — 93

7.4 Founding the Historical Constitution? The Golden Bull — 93

7.5 Stephen Werbőczy — 94

7.6 Stephen Bocskai — 96

7.7 Transforming and Reflecting Upon the Historical Constitution: The Eighteenth Century — 97

7.8 The Golden Age of Historical Constitutionalism: The Nineteenth Century - 99

7.9 Anachronistic Afterlife, Death and Revival (?) of the Historical Constitution: The Twentieth Century — 101

7.10 The Achievements and the Failures of the Historical Constitution - 105

7.11 How to Reinterpret the Tradition of the Historical Constitution? - 108 Bibliography — 110

Arkady Rzegocki

$8 \quad$ Polish Constitutional Traditions - 113

Bibliography — 121 
Igor D. Osipov and Leonid V. Smorgunov

9 Russian Constitutionalism -123

9.1 Philosophy of Law and Constitutional Ideas in the 19th and Early 20th Centuries - 125

9.2 Ideas of Soviet Constitutionalism - 130

9.3 Constitutional Ideas of the Human Rights Movement in the USSR 134

9.4 Constitutionalism in Today's Russia 139

Bibliography — 141

Bogdan Szlachta

10 Theoretical Problems in the Preamble to the 1997 Polish Constitution in the Perspective of History of Political Thought -144

Index -154 



\section{Editors' Note and Acknowledgments}

The aim of the present volume is to discuss the notion of constitution from the perspectives of history of political thought. Its scholarly intention is to go beyond the approach concentrating on the formal understanding of constitution and bring forward more complex historical and philosophic-political interpretations. Our point of departure was the need to revive the somehow neglected distinction between the idea of constitution as an act of conscious law-giving activity and the notion of constitution conceived as the set of fundamental political rules derived from the very nature of political regime and its historical development.

We are fully aware that a multi-authored volume cannot retain the coherency and methodological unity offered by a single-authored monograph. Nevertheless, the heterogeneous character of this volume is mitigated by the effort of the authors to engage the problems of constitutionalism in historical-political perspective.

We would like to express our thanks to Dr Kálmán Pócza from Pázmány Péter Catholic University in Budapest for helpful remarks and suggestions. We also thank all the authors for their contributions. Finally, we would like to thank Katarzyna Michalak from De Gruyter Open for her assistance and advice.

Dr. Arkadiusz Górnisiewicz and Prof. Bogdan Szlachta Faculty of International and Political Studies The Jagiellonian University in Kraków 



\section{Bogdan Szlachta ${ }^{1}$}

\section{The Ambiguity of Constitutionalism}

Presently, in literature on the subject, the term "constitutionalism" (from the Latin constitutio - "polity," "constitution") is usually associated with the rule of law, a political system in which government actions are taken on the basis of and within the limits set by law. By such an association, the constitution is seen as a normative act of the highest order, from which the highest public authorities (forming and applying the law) draw their authoritative competences. Constitutionalism, therefore, would refer to the most important element of reflection about the "legal state" (Rechtsstaat), in which every act of authority is based on and remains (or should be based on and should remain) within the framework defined by law. Without going into divagations about the legal state, carried out since the second half of the nineteenth century and usually in connection with the popularization of legal positivism, or about the criticism of the supporters of normativism conscious that positivism, contrary to its essence, does not justify the existence of standards from which the legislature derives its right of fixing normative acts, since it is to be the authority setting the provisions of constitutional status, it should be noted that historians of political thought speak carefully about the dominant association of constitutionalism with the concept of providing for the existence of a written basic law. Even if they join in a debate led by lawyers or political scientists engaged in the study of constitutionalism, they still claim that the concepts justifying the restriction of the will of legislators by some normative requirements appeared already in antiquity, not finding them in the written "basic law," but in the standards of customary, fundamental rights, the standards of God's or natural law as well as the law of nations, hence in the standards of a "higher law" preceding and limiting the will of the legislator. ${ }^{2}$ According to historians of political thought, the term "constitutionalism" describes concepts that justify

1 The Jagiellonian University in Kraków.

2 See i.e.: Elkin and Soltan (1993); Elster (1988). However, while the rules binding the will of the authorities, and perhaps also setting the grounds for the system in which they work, need not be included in the written act, they should have a normative and not merely nominal value, since otherwise even the written constitution is not honoured by the authorities (although a respect for it is required from the governed). For example, until the late 1980s, in the name of achieving the objectives set by the communist ideology the authorities in the so-called "people's democracies" frequently violated regulations of the nominal constitutions, did not honour any solid legal principles, following the rules determined arbitrarily or they were guided by the terms of the current effectiveness of the actions; despite the fact that these constitutions granted the citizens of these states (here I am avoiding the problem whether or not they were states) individual rights, for example, to freedom of expression or assembly. The authorities involved in formal constitutional regulations sometimes applied other rules (of an extra-constitutional or even non-legal character), challenging the rights formally held by citizens.

כ Open Access. (๑) 2017 Bogdan Szlachta, published by De Gruyter. (๔) BY-NC-ND This work is licensed under the Creative Commons Attribution-NonCommercial-NoDerivatives 3.0 License. https://doi.org/10.1515/9783110581928-001 
opposition to despotism/tyranny (in which the will of the ruler is not limited by a "higher law," but is treated as the only source of law), and today also against authoritarianism, referring sometimes to a written constitution, but to some extent allowing actions against the rights and freedoms of individuals. The dominant approach today, binding both constitutionalism and the rule of law with the context of the rights and freedoms of individuals leads, however, in a different direction than the constitutionalism which, for the purposes of this text, can be called "classical." Such an approach exposed the existence of a "higher law" as a kind of a "normative constitution" of a community with a material value (defined by natural, fundamental or customary law); in the attitude prevailing today more attention is given to the need to ensure the rights and fundamental freedoms of individuals in the written law, and to identify a number of operational procedures of public authorities, in which they should exercise their competences, indicated also in the written law. ${ }^{3}$

In a contemporary sense, constitutionalism was to be born as a result of the denial of absolute monarchy in the $17^{\text {th }}-20^{\text {th }}$ centuries, and the introduction of a constitutional monarchy in which the king, remaining the highest public authority, was to operate on the basis of and within the framework specified in a written act (even if he were to impose it by himself). It is worth noting that this approach was formulated at the end of an evolutionary process spanning many centuries, during which there were also other options considered by historians of political thought as constitutionalist, ${ }^{4}$ referring to the "higher standards" associated not with the non-existent (as of yet) written constitution, but with the rules limiting the will of the legislature or the assessment criteria of its decisions.

In antiquity, these standards were associated with natural law, understood in various ways, and requirements of the common good. Recognizing that the normative order should allow for the fulfilment of the requirements of human nature, thinkers of this period - such as Aristotle and Cicero - limited the will of the legislature indicating the material norms, and at the same time set the safeguards for the rule of law in a system that would protect against arbitrary actions of the members of the ruling class. The term politeja used by Aristotle referred not only to a certain type of good regime or form of government contrasted with the evil forms of rule (such as

3 Although constitutionalism is usually associated today with the existence of a written constitution (a benchmark for decisions taken by constitutional courts or courts of law, independent from the legislative bodies), historians of political thought emphasize that even in some modern political systems there are rules (considered constitutional) binding the will of authorities and having for example customary value. That is why the modern state, even if lacking a constitution in the written form, can meet the requirements of constitutionalism,"being ruled by an unwritten "constitution" (i.e., rule of law).

4 For example, see Church (1941), Franklin (1969), and also a work by the author of these words, Konstytucjonalizm czy absolutyzm? Szkice z francuskiej myśli politycznej XVI wieku [Constitutionalism or Absolutism? Sketches from the 16th Century French Political Thought] (Szlachta, 2005). 
despotism, oligarchy and democracy, which were to be directed towards the implementation of the interests of the ruling), but also to one of the regimes or forms of government recognized as good because they allowed for the pursuit of the common good. ${ }^{5}$ The criterion for distinguishing the good system or "form" from the bad one would usually be the right to achieve the common good, which Plato thought was accessible to the wise through intellectual cognition while in Aristotle's thinking it was for interacting groups of citizens who recognized the experience of political communities. The Romans, on the other hand, granted this right both to patricians and plebeians who searched for the sources of power and stability of their own state. Polybius, Cicero, and the Roman legists who were influenced by their reflection, sought guarantees for the rule of law that would stabilize and strengthen the state as a political community led by the authorities, and would not, as the followers of the modern constitutionalism claimed, protect the rights of individuals forming a kind of political association. In Roman political thought the distinction between public and private law, significant also for the later constitutionalism, was particularly important, as

5 Already in the work of the Stagirite there are therefore two elements whose existence must be kept in mind: the element of binding with a higher law and the institutional component, associated by him with the participation of community members in setting norms; it is still worth reflecting whether participation is binding, or rather an advisory. With this feature also the problem of the ambiguity of the term "res publica" is related, which once can be associated with "rzeczpospolita" or a republic as another name for the state,"and other times also with a certain form or system of government, as well as yet another the issue, still crucial for many scholars, referring to the subjective side, to the one who co-creates a republic as a state and not as a form of government. A Polish lawyer, Stanisław Kutrzeba, while interpreting the regulations of the Nihil novi constitution from 1505, writes: "the king is not allowed to constitute anything new that would alter the ius commune and publicam libertatem and would bring damage and harm to everyone to cause violation and strain to reipublicae. Therefore, according to this grammatical interpretation, it is just stated here that the king by the changes will not violate these rights which to the individuals - [...] only those of the nobility - were ensured by the common law (at that time it mainly means ius commune), or the law based on the privileges (libertas publica), because it would be considered as an oppression of the reipublicae." Moreover, the same author notes, that the Nihil novi constitution does not introduce anything new in this regard: "The king, the same as before it, if it was about changing these subjective rights, had to refer to the eligible. Only them, each one of them, has to agree to such a change in his entitlements for the change to come into effect” (Kutrzeba, 1906, pp. 17-18). Everyone, except for nobility, was not included among the people or, in other words, the nobility constituted the people. Shedding further burdens on the townspeople, peasants and other (necessary, according to many political writers of the sixteenth century) "members of Rzeczpospolita," a nobleman, "not having any non-free obligation on him," as Stanisław Orzechowski wrote in the sixteenth century, "does not owe anything to the king or the suzerain lord, but only: the title on the lawsuit, two pennies of the fief to the common war, and for a Pole there is no fourth thing in the kingdom" (Quincunx, cit. after: Orzechowski 1919, p.231). In spite of its name, the then Rzeczpospolita was not "a single body of a living creature, all the members of which are animated by one spirit all the actions of which flow from a single source" (cit. after: Koranyi 1955, p.477), instead, it was limited to Polish knightly and the crown council, the nobility and the clergy (Quincunx, p.246). 
was the thesis that even though the people are not the permanent owner of legislative authority, they are the original ones who cede it to rulers. Although the Romans, perceiving at times a higher law in the norms that were formulated over an extended period of time, took advantage of these norms to limit a ruler who derived legitimacy from the assignment of the power carried by the people, there are certain norms in the codification of the mid-sixth century CE, set by the order of Emperor Justinian the Great, in which the ruler-legislator is sometimes recognized as the sole source of law, or even as the "living right." Both threads present in the Roman juridical tradition, which in large measure would later be drawn from by medieval legists, would appear, and sometimes even in a pivotal role, in such diverse currents of political reflection, as the absolutist and the constitutionalist.

Classical constitutionalism was known already in the Middle Ages. This is proven not only by the remarks of St. Augustine on "reliable justice" as the basis of a real state, and by St. Ambrose on "good faith" uniting all the members of a political community and obliging also its rulers to appropriate action, but also by the attempts of the church hierarchy to determine a space independent for the secular power. The announcement of the demarcation of the spiritual and secular spheres, combined in the pre-Christian ancient tradition, and their subjection to separate authorities in order for man to fulfil his true goal (achieving salvation), present for instance in the dualistic conception of St. Gelasius I at the end of the $5^{\text {th }}$ century CE, was gradually linked more clearly with the postulate to limit the powers of secular rulers, by depriving them, among other prerogatives, of the power to regulate the truths of faith and to allocate the posts in the church (one of the reasons for the dispute over investiture in the $11^{\text {th }}-12^{\text {th }}$ centuries).

Also on the subject of lawmaking, the church gained increasing importance during this time, both in setting the standards in some areas of public law (e.g. family law) and in controlling the standards determined by the rulers and the activities undertaken by them (as, for instance, in the case of the early medieval concepts justifying the need to obtain the consent of his subjects by the secular ruler for any action taken, according to the regulations of the synod held in Toledo in 636). The notable development of the concept of natural law, whose purpose was to designate the negative limit of legislative freedom and provide a criterion for assessing the actions of rulers, was accompanied by reflection on the effect of the promises made by the rulers in the coronation oath, related in particular to ensuring the subjects' safety and the protection of the church. The fulfilment of duties by the ruler (and not his moral values) was the main theme of reflection for the thinkers of the late Middle Ages who associated the thesis of "the orienting power of the standards of higher order" with the thesis about the possibility of obtaining support from the pope or the community for the "binding force," a permanent law binding the will of rulers, including the use of the sanction of dethroning in case of its persistent violation (a problem present mainly in the dispute between the supporters of the "divine right of resistance," called "monarchomachs," and the creators of the doctrine of the "divine right of kings"). 
The belief that a Christian ruler, as a Roman patrician, should effectively protect the rights of the subjects and respect the freedom of the church, or else, being useless to the community, expose himself to the risk of deposition similar to that which struck Childeric dates back to the mid-eighteenth century at the latest. The new criteria, considered more important than the hereditary title of the king, were included in the juridical formulas after the statement by Gregory VII, who delegated the power to judge whether the ruler is just, or whether he is a vicious and sinful tyrant, not to the people and the clergy, but to the Bishop of Rome. In this way, the pope of the second half of the nineteenth century, contrary to the tradition that insisted on treating a tyrannical ruler as God's punishment, refused to grant the legitimacy to rule Christian subjects to anyone who did not respect the requirements of justice.

In developing this idea, already in the twelfth century, John of Salisbury, whose name is associated with the concept of tyrannicide, and the canonist Rufinus, recognized the fair establishment and implementation of justice as the criteria that distinguish a Christian king from a tyrant, combining the standards of justice not so much with the natural law, but rather with the content of the customary laws of the kingdom and the commitments made by the ruler in the coronation oath. This direction was taken by the canonists, the supporters of papalism and hierocracy, and also individual popes, like Innocent IV, who in 1245 dethroned the Portuguese king Sancho II (without depriving him of royal dignity) and bestowed the right to rule on his brother, Alfonso III, as a more useful pretender. He also spoke out against the emperor Frederick II, accusing him of tyranny, violations of the rights of the church and the coronation oath. Over time, the feudal lords also began to proceed in the same direction, demanding respect for the privileges conferred on them. Consequently, next to natural law (associated mostly with the divine) and the independence of the church as a community enterprise provided with its own sphere of activity, the privileges of secular and clerical feudal lords gradually gained more importance, thus becoming specific subjective rights, which were also to establish the limitations of political power and even co-create the content of what was eventually collectively considered the fundamental rights of the kingdom.

The conflicts of the universal or local church superiors with the rulers of the laity (the emperor, kings) and the disputes of the latter with the feudal landlords or other bodies representing the community, also led to the establishment of institutional guarantees of such rights and the application of sanctions in case of their violation. Magna Carta Libertatum of 1215, many times confirmed by the later rulers of England and used by, among others, Edward Coke in polemics with Stuart King James I seeking to consolidate monarchical absolutism, announced a condition in which the contract and not just the one-sided coronation oath, was to bind the ruler. But before the dissemination of such a solution, usually requiring a written act, it was the customary right, the consent of the representatives of the people to constituted law and the subjects' right of resistance in case of a violation of the law by the ruler, which 
were the main features of constitutionalism. ${ }^{6}$ The seemingly paradoxical thesis of the concurrent primacy and subordination of the will of the king to the law was understood at that time and preached by many authors of the late Middle Ages, including St. Thomas Aquinas. Also, for example, Henry de Bracton proclaimed that "higher law," equal to the natural law or customary law of the kingdom, should "guide" the actions of the ruler, who is entitled to change it only in exceptional conditions. ${ }^{7}$

Attempts to subject Christian lawmakers to the pope's judgment, which would have the authority of release from obedience to a maleficent ruler, sometimes regarded as a factor reinforcing the development of late medieval constitutionalism, aroused opposition especially after the emergence of the so-called national monarchies, ruled by kings as emperors in their own kingdoms. The problem was, however, that a monarch recognized in such a way sometimes set the norms for the actions of his subjects at the expense of their privileges and without the participation of representative bodies, not honouring the interference of his superiors with universalist pretensions (the emperor and the pope, which would become the subject of reflections of John of Paris and will almost universally be echoed by the thinkers of the sixteenth century, being linked, to some extent, with the development of Gallicanism). Polemics conducted by the legists (e.g. Azo and Lothair) with regard to this issue were concerned with similar problems to those considered by the supporters of papalism and conciliarism, when it comes to the system of the church. The problem of the source and scope of the political leader's power again became the center of reflection: advocates of constitutionalism still preached the primacy of the common good over the arbitrary will of the ruler, stressed the corporate nature of the kingdom, defended the privileges and demanded taking into account the will of the representatives of the community in lawmaking.

Also, by using the jurisdictio (legislation) and gubernaculum (state management) distinction introduced by Bracton, they granted absolute power to the monarch only in the second sub-field. A French lawyer, Philippe de Beaumanoir, formulated the concept, characteristic of this period, of a ruler enforcing a common customary law, and introduced the problem of the relationship between the written law and the customary local law (so important for the Germanic tradition), significant in this regard (Wilks, 1963, pp.206-207). While Irnerius, at the end of the eleventh century, proclaimed that customs should be honoured only so far as to not contradict the demands

6 More on the subject, see Kern (1939).

7 The issues that are today usually associated with the constitution or the system concerning, for example, the division of powers, were regarded therefore as secondary, because more attention was paid to the presentation of a model ruler, conscious of limitations, and to bending his will in a suitable direction, than to building institutional governance models and determining the relationships between various authorities. For the ruler, representing God on earth, established the law not so much as its author, but as a judge pronouncing what is right and just, that is, consistent with the fundamental laws of the kingdom, including customary laws. 
of reason or the law established by a wise ruler, seeking thereby to strengthen the role of the written law. Azo, at the beginning of the thirteenth century, claimed that customs should be treated as a measure of written rules, shaped in a long process.

The position of Azo was also close to the one of Beaumanoir and of the Englishman Henry Bracton. However, Irnerius's approach gained more and more importance. Thus, by separating the content of legal norms from rationality and customs, and by making such jurisdiction dependent on the will of the ruler, jurists began to consider all legislative judgments of a ruler as legal standards established in the course of the procedure prescribed by law, even those which were irrational or contrary to existing customs. By removing the value of rationality or dependence on the customs, essential for the gradually rejected juridical tradition dominant for several centuries, outside the discussion on the essence of law, legists of the late Middle Ages reached for the category of the common good, essential for classical constitutionalism, but acknowledged that it would need to be linked with the utility of the community norms determined by the legislator. The criteria for correctness of the will of the legislator, reduced in this way, failed to protect the existing legal system against changes; on the contrary, because of these criteria, the ruler, adjudicating on the content of the common good, could impose new norms honouring the requirements of the legislative procedures, without respecting the legally binding power of customs without exception (Pennington 1991, pp.424-429).

It appears that the double defence undertaken by Beaumanoir and Braxton (against the consequences of separating the rationality and law, and against the proceduralization of law) was more effective than the return to the old approach, followed, among others, by St. Thomas Aquinas. The appeal to the rational order of creation proved to be less legitimate than the appeal to the spontaneously emerging custom, while a sense of the existence of the universal normative order, enhanced by the particularization of the universal Christian community and atomization within political communities, fundamentally weakened in the following centuries. An attempt to combine both positions, also undertaken numerous times in the political thought of the sixteenth century, would prove successful as far in terms of referring to the customs' antiquity; the custom was to have a foundation that would reach rationality but, after all, in some of the approaches it would determine the substantive content of the ruler's will, shaped in the appropriate way. ${ }^{8}$

8 A.J. Carlyle (1941, p.14) states that the position of Beaumanoir differed significantly from that which is sometimes considered the announcement of the absolutist trend in sixteenth-century French political thought, and which involves the work of a thinker of the turn of the fourteenth century, Jean de Terre Vermeille (Terrevermeille or - as stated more and more frequently in the literature - Jean de Terre Rouge or Johannes de Terra Rubei), who in his Contra rebelles suorum regum employed the category of dominium to demonstrate the centralized nature of the hereditary French monarchy, understood as one political body subject to one ruler-owner, who acted to maintain justice and peace in the political entity ruled by him. (Burns, 1985, p.797). See also Dunbabin (1988). 
Discussions about the relationship between customary norms and the rationality of the legislator determined the context for the changes leading to the disorder of feudalism, particularly to the replacement of relationships based on private legal relations by the norms of public law, to approaching the law less in terms of individual or group privileges justified by tradition and more as a set of general fundamental norms (determining even the order of succession of the crown and prohibiting the divestment of goods belonging to the domain of the crown), the respecting of which by the ruler, understood more as an administrator than a legislator, was to be guarded either by a body composed of representatives of the states (according to Francois Hotman) or an office (e.g. the ephors, according to the other followers of Calvinism), or a part of the kingdom (e.g. the provinces, according to Johannes Althusius).

The Renaissance advocates of constitutionalism not only opposed the absolutist tendencies, but also built the foundations of modern republicanism. Reaching for the legacy of the Romans, they recalled the classic concepts of mixed government proposed by Polybius and Cicero (e.g. Coluccio Salutati, Leonardo Bruni), to some extent using the findings of Marsilio of Padua, who justified the supremacy of the people, but also the arguments of John Fortescue, who in the fifteenth century made a distinction between dominium regale and dominium regale et politicum in a manner reminiscent of Aristotle's analysis of politeia as a good system. In a similar direction, in the fifteenth and sixteenth centuries, proceeded Thomas Starkey and the representatives of the school of Salamanca, Guy Coquille, John Mair and Jacques Almain. They believed that the people, ceding the originally held power on the representatives embodying the mystical body of the community, had authorized them to legislate together with the king, leaving in his hands all current administration of the state. Accepting such arguments, in his polemic with the Concilliarists, by Cardinal Gaetanus (Tommaso' de Vio) who did not agree with the concept of the power of the people, neither in the form of the current administration of the state exercised by the people or their representatives, nor in the form of bestowing the administration on the king, who would act following the norms set by the people or their representatives (regimen medium), the aforementioned thinkers had already distinguished the power of the community (as a collective superior) and the power of the monarch who was to draw jurisdictional and administrative authority from the community; the community no longer understood as a corporate unity personified by its head, but rather as a collection of individuals equally responsible for the common good. ${ }^{9}$

At that time, the constitutionalists tried to work towards a slightly different position by discussing the problem of the independence of courts and representative bodies in the process of establishing constitutional rules. ${ }^{10}$ The sixteenth-century

9 For more, see Kern (1939), Dicey (1947); Wormuth (1949), Friedrich (1957), Pennock (1979), and especially Tierney (1982).

10 Ibid. 
French thinker Claude de Seyssel, who imposed some curbs on the ruler (including the verification of his decisions by the judges of the royal courts, and periodical meetings of the nobility and clergy), and the English author Richard Hooker, almost his contemporary, defended fundamental rights equally against the supporters of variously justified absolutism, who identified the will of the king with the law, and the followers of new ideas, inclined to associate the legitimacy to rule with a direct divine intervention and, in the name of Revelation, to challenge the existing customary rights (e.g. the Puritans).

The discussions about the independence of the courts and the role of representative bodies in shaping the legal order played a special role with regard to this issue. Fortescue and Coke in England underscored the importance of both factors, stressed the need of the sovereign to honour the law that was shaped over a long period of time and was not deliberately designed by anyone (i.e. the common law). Therefore, they did not agree to recognize the will of the ruler as the only source of law; at the same time, they claimed that the king, acting together with the representatives of the upper and the lower strata (bicameral parliament), should only supplement the applicable law, but not alter its essential clauses, even in the name of God's mission, with reference to the authority allegedly bestowed on him by God, or even by invoking the dictate of the right reason.

Already in the sixteenth century, Thomas Smith proclaimed that the parliament exercises the supreme and absolute authority, that ultimately both the legislative and the judiciary power are placed in its hands, and only the parliament is entitled to derogate the old laws and introduce the new, and to exercise judgment in disputes between private individuals. Not only the English, but also the French absolutists proceeded in a different direction in order to justify the full power of the king, not the parliament. In the first half of the sixteenth century de Seyssel stated that judges of parliaments exercise independent permanent power, and that the monarch cannot deprive them of their functions. The legists of the second half of this century (especially Charles Dumoulin), on the other hand, though they noticed a distinction between the private and the mystical side of the monarch, began to treat all the organs of the state, including the royal council and the parliament, as parts of the mystical body of the one who gives life to the law. Taking into account the consequences of the debates waged in the sixteenth century between the followers of constitutionalism, who defended the fundamental rights, and the supporters of absolutism, who refined their scope to the rules that determine the order of succession of the crown and the restriction on the disposition of the domain, it should be pointed out that they led to the formulation of the fundamental reasons for the independence of the judiciary, the determination of the rules for dividing the realm of legislation (settlement of issues concerning the body of the kingdom) from the sphere of the judiciary (settlement of specific cases), and thus made it possible to distinguish between the spheres of private and public, of which the first was subject to the king and/or representative bodies, and the second to independent courts. 
The dispute over the body of the highest commanding authority dominated the political reflection of the subsequent centuries and pushed the issue of fundamental rights into the background. Although constitutionalism sometimes combined with the doctrine of ancient constitution and the approach to the political community as a kind of a corporation remained alive in England (e.g. Henry St. John Bolingbroke, Edmund Burke), with time it began to encounter resistance both from the absolutists and the supporters of individualistic approaches. Still recalled against absolutism, among others by Francois Fenelon, constitutionalism increasingly lost its takings in favour of the positions based on the concepts of inherent powers of the individual, the division of power, and the social contract. These positions not only assumed the need to consider the different function of a mixed government (protection of individual rights, not of fundamental rights), but also accentuated the importance of a conscious act constituting the foundations of the system, which was over time associated with the postulate of drafting written constitutions.

Modern constitutionalism, usually called liberal-democratic, mainly due to the doctrines elaborated by, among others, John Locke, is based on the thesis that the freedoms and rights of the individual are properly protected, as long as the order designed in the constitution honours the restriction on the mutual violation of such rights and freedoms; in a broader sense, however, it leads to demands for the deconcentration of the central government and decentralization of power to local government authorities, to ensuring judicial control of the constitutionality of normative acts and the legality of administrative acts, to multi-instance independent courts of law, to controlling the actions of authority by the political opposition and to respecting the powers of the various minorities by the dominant majority. Two forms of modern constitutionalism are typically mentioned in this context: the continental (European) and the British, differing not only in terms of the lack of basic law in the form of one written act in the latter, since Albert Venn Dicey argued that an important feature of the British constitutional system is not that the law is binding to all citizens, including those in power, but that "every man, whatever be his rank, shall be subject to the ordinary law of the king and is responsible before an ordinary tribunal” (Dicey, 1945, pp. 193); whereas the continental constitutionalism normally exempts the public administration authorities from the jurisdiction of the ordinary courts, thus differentiating their legal position and the position of citizens. For instance, Immanuel Kant, while demanding that the king and subordinate executive bodies refrain from interfering in the administration of justice, declared that they cannot be held accountable by the citizens, and that the latter should put up with the unfortunate decisions of the administration in the hope that the administration itself will correct them.

Some authors argue that one of the reasons for the dissimilarity of the continental constitutionalism is the legacy of Roman law (especially the so-called right of intercession, which allows an official to suspend the decision of his equal; for example, a consul could suspend the decision of another consul or might question a decision made by an official of lower rank, as in a praetor's decision could be questioned by a 
consul). For Lon L. Fuller, intercession was a prefiguration of the division and balance of power, through the prism of which Montesquieu marvelled at the solutions introduced by British constitutionalism. Its dissimilarity is also a result of the different evolution of the English and continental legal systems: the role was played by the decisions of judges in the former of these systems was not exposed by Montesquieu, who also stated that British judges are only the mouth pronouncing the words of the law, which weakened their role.

Meanwhile, it seems that the key component of the British constitutionalism is the decoupling of the sphere of citizens' freedom from the decisions of the parliament and combining it with precedential judgments which eventually gained legal value (for this reason the British constitution is sometimes considered to have been created by judges: a judge-made constitution), despite a different interpretation dominant among the Whig theorists of constitutionalism (e.g. Walter Bagehot). On the continent, however, not only under the influence of absolutist doctrines and actions of the kings, but also of the rationalist or utilitarian-minded liberals, both individual rights and the law as a set of legal norms or rules guaranteeing them, were deprived of their historical roots. Such constitutionalism could have given rise to a tendency to regard entitlement as an arbitrary gift of, understood in one way or another, a constituent assembly or king-legislator; a tendency to treat written constitution as the source of freedom of individuals and intermediary bodies, contrary to English tradition, according to which freedom is the foundation of constitutional order rather than its result. ${ }^{11}$

Although the dispute between the advocates of constitutionalism, preferring the reflection on law which is independent of the will of the legislator, and the followers of constitutionalism, emphasizing the institutional dimension and proclaiming the primacy of individual rights (also recognized as supreme to the will of the legislator) continues to this day, it seems that the influence of both legal positivism and normativism increasingly reinforces the conviction that only a written constitution is able to determine the principle of the rule of law and ensure the aforementioned solutions. Difficulties in terms of changing the regulations of the constitution imposed on the legislator, however, today seem to direct the attention firstly to the procedural norms, while largely turning away from reflection on the basics of the material order, which is most often subjected to the general criteria of utility, set by the consensus between competing political groups, or by mechanical voting (either in parliaments

11 While some of the radicals decoupled the reason of a legislator from the traditional foundations and pointed to the utility as the sole directive binding the will of a legislator, the British Wigh-conservative, Burke, praised prejudice as a link in ensuring the historical and constitutional continuity, an effective inhibition for legislative authorities and, above all, a source of knowledge about the limits of the freedom of the legislator. Continuing the traditions of Bractona, Fortescue and Hooker, he repeated arguments put forward by Coke against the pretensions of James I, attributing to himself the supreme power of judges, and by Francis Bacon who preached the apology of natural reason of a legislator as the sole source of law, akin to continental thinkers, his contemporaries. 
or in referendums). In this way, and the announcement of the contemporary approach can be found in the work of the inter-war period (including that of Carl Schmitt), the constitution is associated with an act of a conscious decision on the content of the system, or with the expression of the will of the sovereign authority, even if the act, as in the case of Hans Kelsen, refers to the basic norm (Grundnorm).

Recognition of the precedence of the will of the authority against any higher law, which would by definition restrict it, poses a serious challenge for contemporary constitutionalism, targeting almost exclusively in the opinion of many scholars, out of necessity against the erosion of the common good, the protection of the rights and freedoms of individuals and the rule of law which embodies the standards and defines the characteristic virtues of the legal system as such, safeguarded by the constitutional judiciary as a specific guarantor of the legal state.

\section{Bibliography}

Burns, J. H. (1985). "Fortescue and the Political Theory of Dominium.” Historical Journal. Vol. 28.

Carlyle, A. J. (1941). Political Liberty. A History of the Conception in the Middle Ages and Modern Times. Oxford.

Church, W. F. (1941). Constitutional Thought in Sixteenth-Century France. A Study in the Evolution of Ideas. Cambridge.

Dicey, A. V. (1945). Introduction to the Study of the Law of the Constitution. London.

Dunbabin, J. (1988), Government. In: J. H. Burns, M. Goldie (Eds.), The Cambridge History, (pp. 485-487). Cambridge.

Elster, J. (1988). Constitutionalism and Democracy. Cambridge.

Elkin, S. L. and Soltan, K. E. (Eds.) (1993). A New Constitutionalism. Designing Political Institutions for a Good Society. Chicago.

Franklin, J. H. (1969). Constitutionalism and Resistance in the Sixteenth Century. Three Treatises (Hotman, Béza, Languet). New York.

Friedrich, C. J. (1957). Constitutional Reason of the State. The Survival of the Constitutional Order. Providence.

Kern, F. (1939). Kingship and Law in the Middle Ages. Oxford.

Koranyi, K. (1955). Rys stosunków ustrojowych i prawnych w państwach europejskich i w Rzeczypospolitej Polskiej w XVI wieku [An outline of political and legal relations in European countries and in Rzeczpospolita, in the sixteenth century]. In S. Arnold (Ed.), Odrodzenie w Polsce. tom. I: Historia [The Reneissance in Poland, Vol. I: History]. Warszawa.

Kutrzeba, S. (1906). Kilka kwestyi z historyi ustroju Polski. Przyczynki i polemika [A few problems from the history of the system of Poland. Contributions and polemics]. Lwów.

Mcllwain, Ch. H. (1947). Constitutionalism Ancient and Modern. New York.

Orzechowski, S. (1919). Polskie dialogi polityczne [Polish political dialogues]. Kraków.

Pennington, K. (1991). Law, Legislative Authority, and Theories of Government, 1150-1300. In J. H.

Burns, M. Goldie (Eds.), The Cambridge History of Medieval Political Thought, c. 350-c. 1450. Cambridge.

Pennock, J. R. (1979). Constitutionalism. New York.

Tierney, B. (1982). Religion, Law, and the Growth of Constitutional Thought 1150-1650. Cambridge.

Szlachta, B. (2005). Konstytucjonalizm czy absolutyzm? Szkice z francuskiej myśli politycznej XVI wieku [Constitutionalism or Absolutism? Sketches from the 16th Century French Political Thought]. Kraków. 
Wilks, M. (1963). The Problem of Sovereignty in the Later Middle Ages. The Papal Monarchy with Augustinus Triumphus and the Publicists. Cambridge.

Wormuth, F. D. (1949). The Origins of Modern Constitutionalism. New York. 


\section{Pawet Kaczorowski ${ }^{1}$}

\section{Epistemology of Constitution}

\subsection{Part One}

In his work The Laws, Plato stated that it is necessary for man to establish law and to obey it, as otherwise he could become similar to a savage animal, and not a human being.

This truth was taken to heart in the $18^{\text {th }}$ century by the bourgeoisie of the Western world and by the end of the Enlightenment it had become the centre of attention among the politically engaged public and also the public opinion at large. This led to the emergence of a modern idea of constitution qua fundamental law. As Ducancel wrote in 1814, the Romance-speaking countries started the constitution fever which later spread all over Europe (Schmale, 1988). The notion of constitution became one of the main subjects of the political controversy all through the $19^{\text {th }}$ century, which is not only considered the century of steam and electricity, but also the century of constitution, law and legislature.

From that perspective it can be said that just as after the Reformation, and the religious wars that it had caused, between the then feuding sides there emerged the so-called third one (the sovereign) who, due to the power he had, built a state which ensured peace, law and order, and security (Forsthoff, 1971), so after the Revolution, in France for example, the sides of the conflict, without the participation of the third one and after the long period of exhausting wars, eventually had to, on their own, come to an agreement which was put down in writing as a document in the form of a constitution.

Neither of the parties could acquire absolute superiority. On the other hand, absolute power was no longer their main goal and it did not constitute the solution to the problem, as was prompted by the just acquired historical experience. Values such as freedom or law and order, which were advocated by both sides, were also no longer treated as mutually exclusive alternatives. The constitution became the remedy for the problem of political competition which earlier would have been found by having a sovereign, supposedly above the fray of day to day politics.

The constitution became the thing which two opposing parties, the movement for change party and the party opposing that movement, could accept as something neutral, superordinate, and objective. It also meant that even though the parties accepted it, neither of them felt as the defeated party. That said, the passing of a

1 Cardinal Stefan Wyszynski University, Warsaw. 
constitution also served peace, which in the $19^{\text {th }}$ century was repeatedly proving to be a temporary, fragile state, constantly endangered by any of the sides involved should the smallest opportunity arise (Schieder, 1950).

From a great variety of ways of understanding the idea of modern constitution, two, according to Hasso Hofmann (1986), deserve our particular attention. The first is the idea of constitution that restricts power and thus proclaims the freedom of an individual and also promotes the idea of emancipation. What Hofmann (1986) understands by this is the guarantee of values such as life, liberty, property, the introduction of the idea of representation, and of the separation of powers. Secondly, the concept of a constituting constitution needs to be mentioned. This kind of constitution establishes a plan of methodical building up of the state, fashioing a rational structure, a tool, a mechanism. Hofmann (1986) reminds us that this concept had also appeared before. It was advocated by a Swiss lawyer and philosopher Emmerich Vattel, who claimed that the constitution is the "nation's plan to acquire happiness" (Vattel, 1959, p.29).

Apart from these two main concepts it is worth reminding ourselves of the typical characteristics of a constitution. According to Heun (2006), these include a written document that is a proclamation at its inauguration, but with a possibility of changing it in the future; has superiority over other laws; enjoys juridical protection regarding its enforcement (this only existed in the USA from the beginning); aims at a total encompassing of the political order and of power. It also possesses universality, democratic representation, the separation of powers, and the rights of individuals as factors restraining power.

As for the basic content of constitutional norms, they include notions of social institutions such as elections, basic rights, the administrative system, the judicial system, the armed forces, churches and religion, education and upbringing, finances of the state, the economy and social support networks and charitable institutions (compare: Brandt et al., 2006).

The constitution which came into existence in the $18^{\text {th }} / 19^{\text {th }}$ century was unique in that it was written, legally binding, and determined the state's institutional, political and social order. It was a constitution which was already modern, a constitution which monopolized the understanding of the notion of constitution. It needs to be remembered that constitution (Verfassung) is a notion that has been known for a very long time and thus it has had not one but several essential meanings throughout its history (Mohnhaupt and Grimm, 2002). Its history dates back to antiquity, and then it obviously meant something different comparing to modern times. Back then it meant a political system, a city-state system (Greek polis), and later another political entity, civitas. The political system was something tangible, which in fact was an existing community, an ordered society - an order (Greek nomos) which consisted of religion, customs (German Sittlichkeit) and also laws. It was, from today's perspective, a special entity because it was not determined by the division into state and society, nor into state and church. This reality, factual and symbolically spiritual at the same time, a 
system that constituted, as it were, the soul of polis (see Aristotle) was not a reflection of any matrix of set legal norms. It was something that was lived, and it was at the same time the essence of the social consciousness which determined this particular society and constituted the common identity. This essence was effectively alive, it was a part of the general image of the world that fitted into the society's religious image of reality. Thus, today, this kind of system or this kind of constitution may be and is called the ontological constitution (Marcic, 1963, 1965).

The modern constitution, that is, as written down and legally binding, was preceded by the ontological one in many epochs. The constitution of the feudal Middle Ages needs to be mentioned as one of the important predecessors. Firstly, it was then understood metaphysically as a Christian Ordo, that is the natural order where there is place for res politicae (Matz, 1975). Secondly, it functioned as a way of enacting and regulating of social life by the authority which granted freedom and privileges, as a form of official action by sovereign power. This type is closer to the modern times but not exactly the same.

The constitution that preceded the legal written constitution was the one known in modern absolutism, that is, as the real constitution. It was understood as a rational, factual state of things, res politicea, somewhat artificial as it was introduced and constituted by the sovereign authorities. Estate, status - hence: State, lo stato, der Staat. This state of affairs consisted of real relations between authorities, social institutions, common law, fixed forms of common life, traditional offices, royal ordinances and fundamental rights.

Following these different types arrangements there came the modern form: a written constitution which is enacted or imposed by a monarch. It started to appear in many West European countries at the beginning of the $19^{\text {th }}$ century (Grimm).

It needs to be mentioned that apart from the aforementioned two concepts of a modern constitution, some others had already existed at the turn of the $18^{\text {th }}$ and $19^{\text {th }}$ centuries. They could be divided into two categories. Firstly, the ideological and abstract ones, which are based on theoretical reasoning, and those which constituted the so called real-politik (Stolleis, 2001), which means they were the outcome of attempts to adapt the idea of constitution to the realities of political life, especially those realities which none were at the time prepared to challenge.

The first category included the concept of constitution as a social agreement, a social contract (see Rousseau, 1762), the concept of an abbot from Chartres, Emmanuel Sieyès, in which constitution was the result of the constituting power, pouvoir constitutionelle/pouvoir constituent; then also ideas of François Guizot, who perceived constitution as a collection of rational and thus common sense and indisputable rules (compare the Declaration of the Rights of Man and of the Citizen); and also ideas of constitution that is the result of the self-consciousness of a nation in which it is an act of self-enactment as a political entity.

The second category includes, above all, the type of constitution imposed by a monarch as an act of grace; constitution as an expression of a straight compromise 
between politically opposed sides; and also a constitution which has a somewhat technical nature, that is, a set of bills which regulate the most important matters concerning the relations of authority. This was not always called a constitution (see French Constitutional Laws of 1875). All these types, whether ideal or real, have been thoroughly described, analyzed and assessed, both apologetically and critically.

All the theoretically described and justified constitutions, which are in themselves intellectual propositions, and even more so the concepts of constitutions which originated from pragmatic considerations, under the pressure of circumstances and conditions related to the real-politik of the day, appeared as a result of historic conflicts which determined the politics of each country, particularly in the course of the $19^{\text {th }}$ century (Schulze, 1998; Winkler, 2009; Langewiesche, 2007).

Generally speaking, it was a conflict between Revolution and the remnants of the Ancien Régime, between the Revolution and Restoration. The stages of the conflict constituted the stages of transformation and development of the political order in the Europe of the $19^{\text {th }}$ century. In this context, even the theoretically ingrained ideas, or ideals, related to constitution-making, began to function differently to what their creators anticipated. This happened not only because they had an own substantive value, rightness and authenticity, but also since they functioned the way they did because they were treated or read as camouflages of ideological positions, as ideas which were engaged, or even militant, polemics hostile to monarchical power, or built for its support and used for its defense.

Looking at the historical context all the constitutions, whether they were proclaimed, discussed, or forcibly imposed, obtained political significance because they all became a tool of politics, weapons in the struggle for power - power which, once obtained, gave further opportunities to act in one's interest. They were promoted by political entities as an expression of their aspirations; their vision of the appropriate mode of life in common; and as representations of their political aims. Behind them there were particular dealings and the will of a particular group or groups; they functioned as supporting or opposing something. In the context of this antagonism, as a tool of politics, every constitution acquired a new meaning. This meaning was expressed by Bismarck in his well-known aphorism: "Keine Verfassung kann ohne Kompromi $\beta$ existieren" (No supreme basic law can exist without a compromise).

Since the outbreak of the Revolution, and especially in the times of Restoration, the constitutions in Western Europe followed the rules of a historical compromise between two opposing sides. This was because the two sides, unlike in the $16^{\text {th }}$ century when the sides were two religious groups which could not agree on a consensus, were, in this case, socio-political groups that had their own aims and interests. The third one, an institution which had hitherto been supreme, that is, in which the state became a party to the conflict, which in turn caused the situation where there was no longer an external arbitrator who could be an independent political power and thus a power broker. The only way to prevent the conflict between the state and society was to create some sort of agreement, a compromise. Every constitution in the $19^{\text {th }}$ 
century was a kind of compromise, not explicit but implied, often messy and partial and not particularly sincere, and therefore merely tactical. But it was a compromise to the extent that it took into consideration the interests, expectations or needs of both sides. The new constitutional law became the means to do so. The law is considered to be an ideal tool to regulate relations between two entities as it is a synonym for justice. Thus, it could be treated as neutral, impersonal, supreme and thus unbiased. It can be used as a means to achieve compromise because it constitutes an autonomous, objective and sovereign sphere.

It can be said that constitutions had the merit of being a relatively neutral legal institution. They created the possibility that the introduction of a constitution would lead to at least partial de-politicization of the social situation and its stabilization. However, due to the same reason, that is, taking place in a radically politicized public sphere, the very imposing of constitutional solutions had a political character. In this situation, the aforementioned solution could only be used when the constitution was a compromise.

There were many ways in which a constitution could be a compromise. Even the constitution imposed by a monarch was an expression of the monarchs' recognition of some rights of their subjects. It was the recognition of their freedom, of their right to be treated justly, of their will to co-exercise authority, and also their right to knowledge about the state and how it functioned.

The constitution to be seen in the law-governed state (Rechtsstaat) also had some characteristics of a compromise. In this way it did not have a limiting character. It was a law which was adjusted to the state. However, it was a law which, when respected, provided the state with the sense of being legitimate in the eyes of the public opinion.

When the differences in beliefs were too grave, or the politicians persistent or unwilling to reach a consensus, then the only way was to restrict the number of bills to the essential ones, and regarding them as constitutional, as they were important to the orderly exercise of power. Therefore, the solution here was to limit the compromise to the minimum. A case in point is the constitution in the French Third Republic.

Eventually, also in liberal democracies, which are constitutional entities, as von Beyme (2004) wrote: "Verfassungen sind Kompromisse im streit von Parteien and Gruppen" (Constitutions are compromises in the dispute between parties and groups) (Beyme, 2004, p.33).

Apart from many ideas and concepts underlying constitution-making in the $19^{\text {th }}$ century there appeared many political systems which could all be classified as Rechtsstaat (Schmidt-Assman, 1987; Böckenförde, 1991) - a law-governed state. In these systems the constitution played a significant role. This tradition, so different from the rule of law, Etat de Droit or Etat legal, is a product of the German culture and science, and has a long history.

The idea of Rechtsstaat diversified over the years (approximately since the 1840's), and this lead to the emergence of two basic, divergent strains. These were the aforementioned formal law-governed states and the material law-governed states 
(Preuss, 1994). Without going into the nuances of these concepts it could be said, as Kelsen (1925) pointed out, that a formal law-governed state is a state that is legitimate and where the law is a neutral medium; it consists of content created by the state. On the other hand, the material law-governed state demands that certain institutions and mechanisms such as the separation of powers or the state's compensatory function must be accepted. What is more, the acceptance of axiological rules such as democracy, liberalism, pluralism and the respect of personal dignity are also crucial.

This essay does not aim to focus on a detailed description of political views but it needs to be mentioned that every form of law-governed state (Rechtsstaat) - and especially the material law-governed state - consists of a certain requirement for power and its structure to be constitutional. It postulates the superiority of the constitution in building the order of the state and law, and also provides conditions which once fulfilled guarantee that the constitution will be meaningful in the light of law (Starck, 1995; Di Fabio, 2001).

\subsection{Part Two}

This section will focus on other than the so far mentioned forms of understanding constitutions and related issues. So far this chapter looked at idealistic projects: ideological, ideal, and realistic concepts of constitutions, and also views which emphasized the importance of a constitution, and the ones which presented and implied the state to be a law-governed state. All of them to an extent functioned as ideological weapons for political subjects. These products of thought that became political instruments, once accepted and passed, unambiguously determined the political, social and economic conditions of Western European countries. In this particular form of the existing law-governed state which determined its order and power in terms of historical reality, the constitutions together with what they created, became the subjects of analyses and cognitive investigations of two parallel scholarly disciplines, which emerged and developed dynamically since the first decades of the $19^{\text {th }}$ century. These are the theory of law and the theory of constitution.

While talking about the specific constitutional epistemology, that is, the constitution, ideas, concepts and investigations which were multidimensional and interdisciplinary, some notions need to be mentioned. These include:

- ideological and political drafts of constitution;

- realistic and pragmatic constitutional models;

- theories of the 'law-governed state' incorporating a constitution;

- theories of law, including constitutional law;

- theories of constitution including theories of the state.

This part will be devoted to the most important problems connected with constitutions in the light of theories of law and constitution. 
A constitution to function needs to be something more than just a declaration, an announcement or a political program. It needs to be an act of normative character with a force of law. The constitution is a fundamental law. This way, it becomes, as a significant part of public law, a subject of the theory of law. Its problems are then looked at from a specific perspective of this discipline whose development since the $19^{\text {th }}$ century in France and Germany was connected with the development of legislation and its significance with the emergence of codification and the general tendency towards it, and with the emergence of new branches of law, that is, specialization and autonomisation of the legal order (Stolleis, 1992; Lutz, 2000). However, placing constitutional law in the system of law is already controversial, similarly to the notion of the specificity of private law and its role in the legal system. The specific character of constitutional law can be seen not only in its close relationship with politics, but also in the enigmatic relationship between this law and power. Unlike in other spheres of law what is different is the notion of the crucial importance of that law, that is, the fundamental law and the relationship between the constitution and its object. The specific character of constitution can also be seen in the fact that it is a law that is constituted and which also associated with a particular phenomenon and sense of alienation.

This essay does not focus on the detailed description of the constitutional issues that are present in the theory of law, however, some issues need to be at least signaled:

a) As opposed to other rights and types of law, a constitution is not constituted by an institution of public law, nor is it a law of higher order;

b) It can be said that the constitution is constituted by a kind of power, but this power is special, it is a constituting power (pouvoir constitutionelle, verfassungsgebende Gewalt). However, the question remains whether after the passing of the constitution the power in question should disappear, or exist in concealment and be constantly ready to take action. Another question regards the nature of that power; whether it is a state or pre-state power, and when it is justified for it to take action;

c) Constitutional law is richly creative in its own way. While other branches of law find their object, the constitution creates it and refers to it. At the same time, a constitution as a product of human action undergoes a characteristic alienation, alienation totale (Rousseau, 1762). It is a law that is a product of a subject, an expression of its will, and after its enactment it becomes a collection of opposing, supreme and limiting norms. It becomes an alienated letter of the law. Fuller (1968) talks about this duality in his Anatomy of Law and so does von Laum (1935) in his classic work Recht und Sittlichkeit.

From the perspective of epistemology of constitution and its problems, among many theories of law, special attention should be paid to the theory of legal positivism. It has a long tradition, especially in Germany, that dates back to the mid-19 ${ }^{\text {th }}$ century. There are many varieties and views within legal positivism. This doctrine had many supporters as well as many opponents. 
The fundamental thesis of legal positivism states that law has a specific nature; its norms have characteristics that no other norms have, whether they are moral or religious. The nature of legal norms is their specific law-related duty: normativity. They constitute their own kind, they are sui generis norms. This is the reason why they create an autonomous, separate sphere or a separate dimension of reality, especially when they constitute a closed system, whose crowning is the constitution. The constitution closes the system.

It might be said that the fact that legal norms are conditioned in various ways is obvious. These norms contain ethical, religious and philosophical contents. They are projects forced through by political parties, various subjects and groups of people holding power. Constitutional norms express various common interests and constitute the result of compromises. They are written on the basis of various ideological credos. They arise based on particular circumstances, and political and social situations. They have a specified background of historic continuities. The question is whether all these are meaningless for the legal norms and their interpretation. A legal positivist would say that they do not matter beacuse it is true that these various circumstances exist and it is an unquestionable fact, nevertheless, that they do not hold any legal meaning, that is, meaning for the law. The legal character of concepts does not exist before and beyond the law. The contextual circumstances can and should be investigated, described and evaluated, but they cannot have any influence on the interpretation of legal norms. Such contextual circumstances and the law have different natures. Therefore, it is impossible for them to influence the content of legal norms. Through intellectual operations, legal norms can be, and should be, taken out of their socio-historical and political causation, they should be separated. The text should be distinguished from the context. It is not an unprecedented action, or an action that is undertaken only when it comes to law. On the contrary, this is done in other spheres of life. For example, while analyzing a work of art, a piece of literature or a scientific work, the focus is not on the author or his biography, intentions, events happening around him which for sure had influence on him and his creation. Similarly, it happens that whenever someone wants to assign some logical value to an utterance, thesis or a judgment. It is treated as an object that conforms to the rules of logic and methodology, and not psychology or sociology. The act of separating the law from facts is not an exception. Besides, the law, the legal norms that a positivist works on are already separated from the context as they had already been abstracted and defined by the relevant institutional actors. Thus, the law for a positivist does not have a subjective, mental, or conscious dimension. It is simply a legal act.

Since the norms need to be separated from events or situations, and especially from political actors, the authorities that helped them to come into being and enacted them, a question arises whether this means that the law is something that is found, that comes from nowhere, is it simply given? A legal positivist would undoubtedly say no. Firstly, what is acknowledged is the internal meaning and achievements of historical and political entities and the act of legislating, but not their meaning for 
law. Secondly, law is constituted but it is constituted by the state, by the authorities of the state. The state, however, is not a socio-historical reality, something separate from the law. It is the subject of law, a legal person who defines itself within the law that in turn is an act of will of the state.

A question may arise, where in all of this is the constitution? Firstly, in terms of a positivist theory, a constitution is not anything special, significant, or something that could significantly be regarded as separate within a given state. Even though it is an act, it is a fundamental law. It is a part of the complete legal order, a part of the state's law and not something mythical or remarkable because it was constituted by verfassungsgebende Gewalt (order-instituting power). A constitution is not a compromise. If it were, as Laband (1876-1882) claimed, it would not be able to bind people. It is not shaped according to a political or ideological blueprint as it does not have any legal meaning, any meaning for the law. Secondly, there is no such thing as constitution, because there is only a collection of norms, which altogether may be called a constitution. But in fact, it is only a collection of norms and nothing more; the collection does not constitute a separate entity. Moreover, this collection of norms does not have any pre-determined common content. It is distinguished due to the fact that it is very difficult to change it. There is also no fixed set of ways as to how to interpret the constitution. Investigating it is based on logical analyses of norms, showing relationships between them, constructing legal institutions, building a systematic whole of the legal order. All this happens as if the law were a positivist subject. A model for a positivist to investigate a constitution is based on private law.

The best known works by legal positivists are the investigations by von Gerber (1876-1882) and Laband (2014), the main representatives of the study of law in Imperial Germany. Thoma, Anschutz and Preuss, the creators of the Weimar Constitution, are also worth mentioning.

To some extent a person who continued the legal positivism was Kelsen, the author of Pure Theory of Law. He further stressed the meaning and the autonomy of the state. A state was no longer a legal person that expressed its will through the authorities. For Kelsen the state was self-limited. Apart from the law there was nothing else. Kelsen's anti-metaphysical stance was very radical. A state did not make the law, it did not bind it. A state was the law. In all this the position of the constitution changed dramatically; it became meaningful. As the law is a hierarchy of norms where all the norms are related to each other and which explains its importance in relating lower order norms to higher norms, a constitution becomes the norm of norms, norma normans. However, its importance needs to be acknowledged by relating it to the basic norm which is hypothetical and presupposed by the theory. The basic norm is necessary as all the lower norms in a legal system are derived from it. It is an idealistic notion and thus quite extraordinary in this anti-metaphysical theory.

Turning to the problems of constitutions in the light of the theory of constitution it needs to be stated that the problems presented here are only a few of the important ones (Winterhofer, 2007). They may be mentioned and not described. They have 
appeared expost in the theory of constitution, or they appeared during the constitutional debate, which started with the emergence of the idea of a modern constitution and is an ongoing process (see Grimm, 1991). The theory of constitution that this article examines is not a discipline which rests on formulating empirical generalizations, but a discipline which has insight into the essence of constitution, and thus has a quasi-philosophical character.

It needs to be remembered that even at the end of the $18^{\text {th }}$ century in France (Morabito, 2014) and Germany there were two meanings of constitution in common use. They were: descriptive or prescriptive; empirical or normative; constitution was considered as an ordered and hierarchical entity or constitution as law. In other words: constitution as a status quo or constitution as a written document.

The basic endeavor of constitutionalism was to introduce a written constitution that would take the place of the status quo ante, the factual state of affairs. However, the status quo ante was not considered to have a constitution at all by many, and it was rather thought by the same people that this state could no longer be tolerated. It was a state of lawlessness and disorder. On the other hand the introduction of a constitution could be considered as hubris, an extreme attempt to revolutionize the world.

The introduction of a written constitution nullified the old order, which meant negating the previous order that was defined by institutions, customs, hierarchies, conventions or beliefs. That order was real, experienced, enriched by tradition in which an individual was rooted. Instead of this historic society (Burke, 1756), there was a plan to replace it with, as it were, a jigsaw puzzle, where one piece could be replaced with another one, that is to introduce a new and artificial state, a collection of general, abstract, non-historical rules written on a piece of paper. The justification for this radical change could only be the revolutionary fever, a state of anxiousness and tension, a need for a breakthrough: creating new foundations for a life in common.

It is interesting that the two meanings of constitution were not always treated as alternatives. Since it was acknowledged, even if it was intuitive, that every community or a political entity is a determined order in itself (but not every entity has it as something that has been constituted consciously), then enacting a constitution - which appeared necessary during the economic and industrial revolution - was not just an act of enactment, but also moving from a status quo ante constitution towards the modern one, which is supreme law. And so, it is a real change. A question may arise about the conditions of such a change. Who in fact has the right to do so, or whether a change like this can be understood as an arbitrary act, which was exactly what the absolutist monarchs were accused of. Another issue is on whose behalf a person may claim that they have the right to do this, what it is going to lead to, and who will pay the highest price for these changes. Another issue is what kind of changes these would be. If they were to happen, would these changes be only allowed 
when the rules are straightforward and fully rational as well as commonly known and having everybody's support?

The constitution as law also required a special form and content. When it comes to the content, it introduced two rules - the rights of man and the separation of powers which were thought to be necessary by many authors and political groups. As for the form, what was required was that it had to be written and officially proclaimed. There were problems with these requirements and they were discussed publicly.

The view that a constitution is a fundamental law and its form is composed of certain rules is in opposition to the legal-natural idea of a social contract. This agreement, a synonym for freedom, is restricted and the fundamental truths are beyond it. The importance of the content does not come from the fact that it was created jointly and approved by the multitude, but that it is considered to be the truth in itself. On the other hand, it can be asked whether a matter of such importance as the constitution and its significance, which is the very ground of freedom, can actually be left to chance, that is left to the speculative and hypothetical notion of the 'social contract'.

What may also be considered controversial is the requirement of giving constitution a written form. On the one hand, giving the constitutional norms a character of an official public document is an efficient way of making the content publicly established, precise and officially binding. It also makes it part of the current content of civic consciousness and a warning for those in power and a reminder of the restrictions to power which must not be forgotten. On the other hand, it can be suspected that questions of this kind only concern something that in itself is unseen despite its declared legal-natural character, and it is all somewhat uncertain and unclear, and possibly unnecessary, since it requires all these efforts. It is also not much of a necessary presence since it remained absent from most of history. The transition from the sphere of belief to the sphere of something that constitutes public content - all the more juridical content of a legal document - is far-reaching and implies serious consequences. It can be said that together with this transition, a community loses its civic subjectivity. In this way the centre of gravity, the grounds for a public order, changes its place. It is not the natural or subjective beliefs but something external, the law. Therefore, the act of proclaiming a normative text is now the ground for political rules, and not their subjective importance. Taking this into consideration, the view that only the recording of positive law is a guarantee of natural entitlements can be insufficient and somewhat contrary.

Another problem concerns the identity of a written constitution or the notion of a constitution. A question may arise whether the word constitution means a kind of thing or whether it is a specific name. Or whether multiplicity of historical constitutions is multiplicity of different documents under the same name, which in fact is the only thing they have in common. This multiplicity can be investigated as one can investigate objects, facts or phenomena. Based on these empirical generalizations one can determine their common characteristics. However, would this be all? There is the question whether behind this multiplicity there is unity, unity of a subject, unity 
of an entity which the constitutional order is, an entity that has different substantiation. Finally, it can be asked whether modern constitutions, which have been so often proclaimed since the end of the $18^{\text {th }}$ century, are volitional acts, so special and specific for a group which has the will or gets the will of being through the constitution. Or perhaps these are intellectual projects that at the deeper level are joined by objective substance and subjective unity. There are many theories of law that analyze the constitutional law which silently acknowledge this unity, as the matter of proper law remains one of the biggest unknowns of the social sciences (Engel and Schoen, 2007). A more philosophical theory of constitution tries to justify this, tries to show what the essence of the constitution is. A constitution is not a notion that is natural, innate, but it is also not a word chosen accidentally, a word that is meaningless. Though defending the hypothesis of the unique kind of identity that supposedly is constitution, it can nevertheless be claimed that despite the fact that there are so many constitutions, they are not empirically equal as there are some which are considered to be models. This distinguishing character is in principle accepted, and even acknowledged by the history of constitution. Moreover, almost every constitution has its substantial content as well as the additional secondary content that can be changed more easily. The former may imply the existence of the essential content of a constitution. There are also the aforementioned concepts of constitution that may contribute an abstract model and in this way they can serve as a joining element between fundamental laws. The notion of the underlying unity of constitutions, its identity, has been debated during the talks on the common European Union constitution.

The legally natural and rational concept of a constitution that was emerging overnight and consciously prepared and instituted in one act was already criticized by Hegel. His critique was on the notion of the state of the constitution as the status quo. He appreciated the constancy of this system and the definiteness of the reality of it. Absurd in his eyes was the claim to consider it as null and void. However, he also claimed that a constitution needs to be considered within a socio-historic and political reality, which is not something accidental, but is a product of the spirit of an age. It has gradually shaped the contemporary being of a national community. The common reality and imponderables must be included in the constitution because they are the constitution. The agreement as such, whether real or presumed, of all the subjects that work together merely constitutes Verstandesstaat but not the Vernunftstaat. It is the organization, and not the state, that constitutes an ethical entity. An ethical state is stable (Böckenförde, 1978) and its existence is deeply rooted. It is also a complex and multidimensional state, which enables a being's self-realization, selfdevelopment and freedom. Meanwhile, Verstandesstaat is something created by accident, incidental unanimity of independent entities, the result of individual decisions. A constitution as a state has a meaning. When this state is pondered and believed to be persistent and stable, and when it is described as a state that consists of laws and institutions, only then will this constitutional system exist as reality and a state of consciousness of the members of the national community. 
Hegel's view on constitution does not only hold historical meaning. Many contemporary authors such as Böckenförde, Isensee, or Hennis point to the fact that postwar $20^{\text {th }}$ century's liberal democracy is a fully functioning Verstandesstaat that lacks ethical-spiritual substance. This substance is important and necessary not only in itself and its significance for man, but it is also necessary for keeping liberal democracy as a working system, and, what is even more important, in order to defend it against the enemies of freedom and democracy.

Apart from Hegel and others, the difference and the existing tension within constitutions - between what, in the constitutional sphere, is the expression of momentary will and is thus explicitly voted in, and what is to be an underlying reality of enduring significance - was pointed out as a problem by Lasalle (1993). He stressed the meaning of constitution and confirmed it is a magical word. However, the real constitution - after the revolutions of 1848 and their suppression in German states was for him the then balance of social forces and the actual relations of power. The written constitution, the document, is a synonym for legality but its real importance comes with the actual degree to which it reflects that real constitution.

The status quo and the descriptive constitution, the relation between empirical and normative constitutions, the importance of real social forces, historical origins of the constitution, are some of the problems pointed out by not only Hegel, Stein, and Lasalle, but also by Huber, Brunner, Schindler, and Hennis in his excellent work. These and the problems that will be mentioned in this chapter can be regarded as being within the range of a broader problem, which the theory of constitution strives to show and analyze. It is a problem of a particular tension that exists between constitution and reality. It is called the constitutional reality. In constitutionalism, especially in Germany, as Hennis (1968) states, the assumption that the constitution is supposed to include everything that is somewhat relevant politically is tacitly accepted. On the other hand, it is obvious that there is always a bigger or smaller difference between norms and real phenomena, which is not necessarily the legislator's fault and the imperfection of legislatures in general, nor can it be dismissed as lawlessness or disrespect for constitution. These constant problems of the system's incongruence and, in this case, the difference between the constitution and the political reality, induces reflection as to whether it should be expected that the constitution will fully and in great detail describe all the relevant relationships. Is it not a false idealism - not false because it is practically unattainable but because it is in principle ill-conceived? Another question is whether socio-political reality is in fact significantly amorphous, if it is not formed by norms. Is it not the case, as the idea of constitutionalism presumably presupposes, that socio-political reality, before it is subject to a constitutionmaking exercise, constitutes, as a living reality, a subject matter of primary importance for the potential law-maker? It has its constituted, though pre-constitutional, state and it has its logic, its rationale, and maybe it should therefore be considered as an ungeschriebenes Verfassungsrecht (Smend, 1928) - 'an unwritten lawful and customary order' - and perhaps it should be an element taken into account when trying 
to interpret and match the written laws to it, and that includes the constitution itself. Is it really enough to make a deal, determine and agree to give these constitutional records effective meaning, or maybe the constitutional law needs to be found, discovered and not legislated? As Kaufmann (1911) argued, maybe it should be discovered in the particular, understood sphere of common life, which in turn needs to be described through norms so that constitutional law can come into existence. It will then acquire the value of objectivity, adequateness, and constancy.

The problems regarding constitutional reality arise when, as Hennis (1968) states, one notices issues that do not allow for an acknowledgement, often automatically made in scientific procedures, of two important reflections. First, that a constitution is intended to comprehensively cover and incorporate the whole of social and political reality. Secondly, law is a different kind of activity to that which is social or historical, and that the latter has no significance for the law and is in fact meaningless to it.

Another issue raised in the theory of constitution is the relation between the constitution (Konstitution) to the system (Verfassung). As Hesse (1993) writes, the constitutional law can only be understood by understanding its object, that is, the constitutional system. This leads to the question whether written constitution construes only a part of the order of the system, which, according to Huber's thesis and Haberle's opinion, is everything that is characteristic for a particular group of people, that is, the reality of social, economic, cultural and political life. In his seven-volume masterpiece Verfassungsgeschichte, Huber (1981) states that the constitution is a collection of spiritual and cultural contents, social tendencies, elements of political order, the essence of ideas or interests, and institutions which together belong to the reality of a particular epoch.

Many constitutional theorists also see the problem in the relationship between the state and the constitution. The essence of this is as to which notion is the original or which includes the other. There is no problem when it comes to the constitution imposed by a monarch as there the sovereign state authority, the monarch's authority, is an entity beyond the constitution, in which case the latter is a voluntary, gracious, self-restricting act for the benefit of society by the constitution-making power. Therefore, it is within the sphere of an existing state that the constitution regulating particular spheres of life appears. In some cases the matter becomes less obvious, that is when the constitution allows for change, but it cannot be undertaken by the sovereign; it can only happen within the limits of the protocol stated in the constitution.

The more the range of norms in the constitution is extended, the more extensive it becomes. It becomes a collection of all elements from which the state's order is composed. The more the state as a specific reality is pushed aside, the more it becomes invisible or even negated as a separate entity. In the debates on constitutional law the question is raised whether the constitution should be seen against a background of a state that is more than the legal order; or a state should be seen as an entity that is constituted through the constitution. For legal positivists in Imperial Germany the state was the creator of law, but at the same time it was a legal entity. 
On the other hand, Jellinek (1900) claimed that the state is not just the law. It has two sides, sociological and legal (Zweiseitentheorie). Also, the authors of the Weimar theory of the state, Schmitt, Smend, Heller, Triepel, and also in a way Kaufmann, opposed reducing the state to mere law and order. For Schmitt, Heller and Triepel the element that existed beyond the legal and constitutional system was the sovereign. However, Isensee (1987) claims that however impossible it is for the constitution to exist without the state which it structures, organizes, and within which it obtains meaning, there also cannot exist a state without a constitution because a particular state is always somewhat constituted. Isensee is trying to build a theory that presents a dialectical unity between the state and the constitution.

Much in the theory of constitution has been devoted to the complicated tensions that exist between the constitution and politics. Constitutional law has sometimes been called political law, that is, a law whose essence is politics; the life of politics that should be legally regulated. A question may arise whether working on constitution should be preceded by investigating what politics is, or regardless of what it is, whether constitutional law should prescribe politics with how it should function.

It is generally acknowledged that the spheres of constitution and politics are not exactly the same, which cedes the ground for political sciences to exist. Constitutional records may be interpreted in many different ways, and often they are very general and allow diverse interpretations and, thus, implementations. Many paragraphs exist only on paper and are not employed or respected. Many political actions are not sanctioned by the constitution. Not everything is regulated in such a document and the rules of the constitution are often bent when need be. It is, after all, the product of politics. All these facts show that the discrepancy between the constitution and politics presents a real problem.

However, what kind of conclusions can be reached from this; how can the reasons for this discrepancy be understood and what kind of counter-measures could be used, which in turn invites further questions. To answer them, as Preuss (1994) says, three models of relations may be presented: it can be assumed that politics is an irrational activity whose rational state is achieved only thanks to formulating it through constitutional law; or the constitution must take into account what is political, as ignoring the nature of politics leads to political crises or catastrophes; or the constitution can release creative powers and potential that exist within politics and create social harmony.

\subsection{Conclusion}

Many problems such as sovereignty of constitution or mechanisms for changing it, or the relation of constitution to constitutional tribunal, still remain to be debated. The scientific, multithreaded constitutional debate continues. Theoretical issues continue to engender curiosity and interest. Its multiplicity and complexity may mean that the 
understandable desire to introduce a constitution in a given country may not be an easy task, but it also does not make the state, or thinking about the state, a problem that is now fully systematized or theorized. New problems, it seems, simply appear elsewhere and continue to complicate matters. Even though the debate regarding the constitution and its dilemmas, paradoxes and priorities continues to develop, the times of constitutionalism seem to be all gone. European societies, even the ones that have just had their new old states restored to them, are no longer concerned with this issue. Writing and passing a constitution is not perceived as a task of primary importance. Loewenstein (2000) paid attention to this fact earlier, when in the 1960's he wrote about devaluation of constitution in constitutional democracies. He pointed to specific indications such as lack of respect for it among the people in authority, the very ones who should obey its rules. There is also an indifference shown to constitution by the masses, combined with ignorance of it and a low turnout when it comes to voting.

Schmitt (1928) may have been right that in the $20^{\text {th }}$ century in a mass society there is no division into society and state, which was exactly the $19^{\text {th }}$ century social infrastructure that made a constitution a necessity. Or perhaps, as Forsthoff (1971) claimed, Sozialstaat ousts Rechtsstaat, or, as Grimm (1991) points out, the problem of constitution, once so oriented to the state, is complicating its growing functions and involvements. Taking this into consideration it can be said that von Stein's prognosis from 1850 was essentially correct, when he foresaw that in a democracy the focus on Verfassung will turn to Verwaltung which takes care of more current matters, especially social ones. And this may be the reason why the administration (Verwaltung) (Dreier, 1991) is becoming so important and theoretically interesting now.

\section{Bibliography}

Beyme, K. (2004). Die Verfassungskonzeption des Grundgesetzes, In Das politische System der Bundesrepublik Deutschland,Wiesbaden: Verlag für Sozialwissenschaften.

Böckenförde, E. W. (1978). Der Staat als sittlicher Staat. (Wissenschaftliche Abhandlungen und Reden zur Philosophie, Politik und Geistesgeschichte), Berlin: Duncker and Humblot.

Böckenförde, E. W. (1991). Entstehung und Wandel des Rechtstaatsbegriff. In Recht, Staat, Freiheit, Frankfurt /Main: Suhrkamp.

Brandt, P., Kirsch, M., Schlegelmilch, A., Daum, W. (2006). Handbuch der europäischen Verfassungsgeschichte im 19 Jahrhundert, Bonn: Dietz Verlag.

Burke, E. (1756). A Vindication of Natural Society.

Di Fabio, U. (2001). Der Verfassungsstaat in der Weltgesellschaft. Tübingen: Mohr Siebeck Verlag.

Dreier, H. (1991). Hierarchische Verwaltung im demokratischen Staat: Genese, aktuelle Bedeutung und funktionelle Grenzen eines Bauprinzips der Exekutive. Tübingen: J.C.B. Mohr.

Engel, C. and Schoen, W. (2007). Das Proprium der Rechtswissenschaft, Tübingen: Mohr Siebeck Verlag.

Forsthoff, E. (1971). Der Staat der Industriegesellschaft. München.

Fuller, L. L. (1968). Anatomy of the Law, Encyclopedia Britannica.

Grimm, D. (1991). Der Verfassungsbegriff in historischer Entwicklung, In Die Zukunft dee Verfassung, Frankfurt/Main: Suhrkamp. 
Grimm, D. (2012). Das Öffentliche Recht, Tübingen: Mohr Siebeck.

Gerber, K. (2014). Grundzüge eines Systems des deutschen Staatsrechts.

Hennis, W. (1968). Verfassung und Verfassungswirklichkeit, Tübingen: Mohr Siebeck.

Hesse, K. (1993). Grundzuge des Verfassungsrechts der Bundesrepublik Deutschland. Heidelberg: Muller Verlag.

Heun, W. (2006). Die Struktur des deutschen Konstitutionalismus des 19. Jh. Im verfassungsgeschichtlichen Vergleich, Der Staat, 45, (3), pp. 365-382.

Hofmann, H. (1986). Zur Idee des Staatsgrundgesetzes. In Politik-Recht-Verfassung, 261-297 Frankfurt Main: Metzner Verlag.

Huber, E. R. (1981). Deutsche Verfasungsgeschichte, vol. 2, Stuttgart.

Isensee, J. (1987). Staat und Verfassung. In J. Isensee and P. Kirchof (Eds.), Handbuch des Staatsrechts der Bundesrepublik Deutschland, Heidelberg.

Jellinek, G. (1900). Allgemeine Staatslehre, Berlin.

Kaufmann, E. (1911). Das Wesen des Völkerrechts und die Clausula rebus sic stantibus. Rechtsphilosophische Studie zum Rechts-, Staats- und Vertragsbegriff, Tubingen: Mohr Siebeck Verlag.

Kelsen, H. (1925). Allgemeine Staatslehre, Berlin.

Laun, R. (1935). Recht und Sittlichkeit, Berlin: Springer Verlag.

Laband, P. (1876-1882). Das Staatsrecht des Deutschen Reichs. Tübingen.

Langewiesche, D. (2007). Europa zwischen Restauration und Revolution, Munchen: Oldenburg Verlag.

Lassalle, F. (1993). Über Verfassungswesen. Rede am 16. April 1862 in Berlin. Hamburg: Europäische Verlagsanstalt.

Loewenstein, K. (2000). Verfassungslehre, Tubingen: Mohr Siebeck.

Lutz, R. (2000). Recht und Ordnung. Herrschaft durch Verwaltung im 19. Jahrhundert, Frankfurt/ Main: Fischer Verlag.

Marcic, R. (1963). Verfassung und Verfassungsgericht, Wien: Springer Verlag.

Marcic, R. (1965). Mensch, Recht, Kosmos. Drei Gedankenwege ins Dasain, Wien: Europaverlag.

Matz, U. (1975). Politik und Gewalt. Zur Theorie des demokratischen Verfassungsstaates und Revolution, Munchen: Alber Verlag.

Mohnhaupt, H. and Grimm, D. (2002). Verfassung, Zur Geschichte des Begriffs von der Antike bis zur Gegenwart, Berlin: Duncker\&Humblot.

Morabito, M. (2014). Histoire constitutionnelle de la France: De 1789 à nos jours, Extenso edition.

Preuss, U. K. (1989). Perspektiven von Rechtstaat und Demokratie, Kritische Justiz, 22.

Preuss, U. K. (1994). Der Begriff der Verfassung und ihre Beziehung zur Politik. In Zum Begriff der Verfassung: Die Ordnung des Politischen. Frankfurt/Main: Fischer Verlag.

Schieder, T. (1950). Das Problem der Revolution im 19. Jahrhundert, Historische Zeitschrift, 170, (2).

Schmale, W. (1988). Entchristianisierung, Revolution und Verfassung. Zur Mentalitatsgeschichte der Verfassung in Frankreich 1715-1794, Berlin: Duncker and Humblot.

Schmidt-Aßmann, E. (1987). Der Rechtsstaat. In J. Isensee and P. Kirchhof (Eds.), Handbuch des Staatsrechts, Müller: Heidelberg, 1987, vol. 1: Grundlagen.

Schmitt, C. (1928). Verfassungslehre, Berlin: Duncker \& Humblot.

Schulze, H. (1998). Phoenix Europa, Berlin: Seidler Verlag. Smend, R. (1916). Ungeschriebenes Verfassungsrecht im monarchischen Bundesstaat. In Festgabe für Otto Mayer. Zum 70. Geburtstag dargebracht von Freunden, Verehrern und Schülern. Tübingen: Mohr.

Smend, R. (1928). Verfassung und Verfassungsrecht, München: Duncker \& Humblot. Starck, C. (1995). Der demokratische Verfassungsstaat. Tübingen: Mohr Verlag.

Stolleis, M. (1992). Geschichte des öffentlichen Rechts in Deutschland, vol. 2, Staatsrechtslehre und Verwaltungswissenschaft 1800-1914. München: Beck.

Stolleis, M. (2001). Verfassungsideale der bürgerlichen Revolution. Frankfurt am Main: Suhrkamp. Vattel, E. (1959). Das Völkerrecht oder Grundsätze des Naturrechts. Tübingen: Mohr, vol.1 
Winkler, H. A. (2009). Geschichte des Westens, Munchen: Beck.

Winterhoff, C. (2007). Verfassung-Verfassunggebend-Verfassungsänderung. Zur Theorie der Verfassung und der Verfassungsrechtserzeugung. Tübingen: Siebeck Verlag. 


\section{Alvydas Jokubaitis ${ }^{1}$ \\ 3 Can the Constitution Do Away with Nation State?}

Constitution today is seen as a tool in the attempt to do away with the nation state and nationalism in Europe. Modern constitutions historically came into being as a tool to safeguard the political form of the nation state. According to the contemporary widespread belief, national patriotism has to give way to constitutional patriotism. The historical experience of the states of Central and Eastern Europe reveals that the adherents of constitutional patriotism have an erroneous conception of the nation state. The nation state is more than just a political form or a legal system. National states are inseparable from their unique national cultures. In Central and Eastern Europe states were established by various nations primarily to safeguard the existence of a concrete nation. The most important political task was understood as being the preservation of the nation. The preservation of the nation and the establishment of a sound political order are two closely interrelated tasks, however, there is an important difference. Even when the nation state loses its statehood it is capable of preserving its own cultural identity. The advocates of constitutional patriotism do not notice that their understanding of constitution is foreign to the experience of Central and Eastern European nations. The cultural constitution in the region is seen as being more important than the political constitution. This reminds us that political traditions and experiences continue to shape the understanding of the essence and function of the constitution. The aim of this essay is to prove that the nation state is more than just a political form which can be replaced by a new political form based on the ideas of constitutional patriotism. The traditions of constitutionalism in Central and Eastern Europe reveal that constitution in the region is seen as being subordinated to the nation and not vice versa.

Constitutional law is understood as a discipline that has its own method of creating norms. Jurists are proud that they can deduce norms from other norms by taking the stance of a disinterested observer, one who does not need to pay any attention to concretely existing social circumstances. The belief that the law can be perfectly understood without considering historical factors today is shared by many jurists. This stance is based on the belief that the constitution can escape from culture. Cultural and historical differences are declared to be of no matter and the most important things are the rules of correct deduction of norms. As an old saying has it, lex becomes rex. Constitutional law becomes detached from the culture and history of the nation, which had produced it in the first place. This process goes against the fundamental modern constitutional principle of national sovereignty. Constitution detaches itself from the will of the people who are the source and basis of its legitimacy and by this

1 Vilnius University. 
detachment arrives at its own logic. This separation of law and cultural circumstances thus becomes a source of the conflict between nation and constitution.

The contemporary experience of the member states of the European Union shows that constitutional jurists in their discourses try to evade the problem of nation as much as possible. National particularities are declared to be of concern only on the private level. Constitution not only becomes detached from the nation, the necessary consequence of this is that it becomes detached from politics. Society and its history seem to be of no importance among the contemporary constitutional problems. Political history disappears from the field of vision of professional constitutional jurists. Today, at least formally, nation still remains sovereign, but this idea is foreign to many contemporary experts of constitutional law. One gets the impression that the state is governed not by the people but by nomos basileus. European specialists of constitutional law attempt to construct a new constitution, which would find its basis and final point of legitimacy not in the nation, but in some kind of principle that would be more universal than the necessarily particularistic nation. The fundamental principle of nation states that came into existence two centuries ago was to protect the rights of their citizens. Today nations face the challenge of constitutional projects that see them as an anachronism that needs to be overcome. This was not the case during the formation stage of the modern nation states. Nation was understood as something that chronologically existed before the constitution.

\subsection{The Phenomenon of Central and Eastern Europe}

The American philosopher of law and politics Paul Kahn argues for a broader perspective on the problems of constitutionalism. His aim is to broaden the horizon of inquiries concerning constitutional law by exploring the political, cultural, and moral aspects of the phenomenon. Kahn writes that constitutional jurists tend to forget the history of the sovereign nations. Their investigations thus are limited solely to the problems of the relationship between legal norms. This perspective proves incapable of grasping the political circumstances under which the nations came into being. By remaining focused only on legal norms, constitutionalists forget that the nation is not a product of a deduction of legal norms, but that it emerged from a revolutionary rupture of society. Modern nations were formed in their struggle for cultural and political identity. Experts of constitutional law do not understand the importance of the struggle that took place two centuries ago. Their methodological presuppositions lead them to neglect the problems of political, cultural and moral philosophy. In the words of Kahn, "Constitutional governance in the United States is less about justice than it is about maintaining this belief in popular sovereignty: if the belief falls constitutionalism can easily become governance by the dead hand of the past” (Kahn, 2011, p.143).

Contemporary experience of the member states of the European Union shows that constitutional law has become detached from the nation. This problem is of 
concern not only to the experts of constitutional law. Political philosophers talk about the gradual disappearance of nation state as a modern form of political organization. Kahn does not pay enough attention to this problem. However, the explanation of the problem is put forward in the works of Pierre Manent. By comparing the ideas of these two thinkers we can gain a better understanding of the relationship between constitution and nation, constitutionalism and nationalism. By detaching themselves from politics and history, constitutionalists are not able to understand the nation as a political form. They are even less capable of understanding the importance of the nation as a cultural form. The cultural dimension is especially relevant to the nations of Central and Eastern Europe. The tradition of political thought in Poland, Czech Republic, Slovakia, Lithuania, Latvia, Estonia and other states is unimaginable without the fundamental question of cultural identity. According to a stereotype, which is very popular among researchers, nationalism in this region of Europe is very different from its Western European counterpart. This popular thinking holds that the political development in Western Europe has to be seen as a movement from state towards nation, while in Central and Eastern Europe the nations had to go through a period of cultural rebirth before they were able to attain their statehood (Kohn, 1967). This important historical circumstance sharpens the problem of cultural identity.

Kahn focuses his research on the importance of politics and morality. He pays little attention to the importance of national culture. According to him, the emergence of modern constitutions is inseparable from self-sacrifice, loyalty, faith, solidarity and other virtues. These factors almost never come into consideration in the works of contemporary experts of constitutional law. They work only with the established legal norms and do not take into consideration the moral factors that were necessary for sovereign nations to come into being. This purely normative perspective is very foreign to the experience of Central and Eastern Europe. The political thinkers of this region were the creators of what could be described as national existentialism. The history of political thought in the region is deeply influenced by the discussions about cultural survival. The historical experience of the nations of Central and Eastern Europe allows us to recognize that the modern nation state is a fundamentally twofold phenomenon. This form of political organization requires some kind of culture, which since the 19th century has been called by the name of national culture. In the region it is customary to discuss cultural problems when one is engaged in a discussion about the political problems. Central and Eastern European political discussions almost always tend to involve a cultural dimension. This important circumstance sharpens the problem of cultural identity in the region. This is the reason why Central and Eastern European nations react more sensitively to changes in sovereignty.

Kahn is engaged in polemics with the positivist position. He aims to show that it is wrong to try to trace the beginnings of the modern nation state to the law. He attempts to find their source in politics and morality. Kahn's investigations are a good starting point, but we have to add that in Central and Eastern Europe national states emerged through the struggle for cultural identity. Before reaching the stage of constitution, 
the nations of the region had to grasp their own cultural identity. Kahn is right that modern nations emerged from revolutionary political struggles. However, in Central and Eastern Europe the struggle for cultural identity preceded the political struggle. The first task of the nations in the region was cultural revolution. Only on the basis of success in this revolution could they aim to emerge victorious in political revolution. Kahn is interested in the political history of the United Stated of America and France and on the basis of these historical cases he explores the link between constitutionalism and political revolutions. To correctly understand the politics and constitutionalism in Central and Eastern Europe, we need to add to his research the analysis of the revolutions of national identity. The nations of the region became sovereign not as a consequence of political revolutions. Prior to staging them, these nations were doomed to undergo a long process of cultural revolutions.

The nations of Central and Eastern Europe were born from cultural revolution. Though the historians of these nations do not talk about revolution, we can only understand the emergence of new nations as a revolutionary event. The unique road of the nations of Central and Eastern Europe towards political independence began with the development of cultural self-consciousness. Universal enlightenment, education and access to the high culture were promised to the members of the lowest strata of society. The nation state in the region emerged not only as political form. Its roots are to be found in the struggle for national identity. The leaders of national movements who wanted to establish the unique cultural identity of their homelands promised a revolution, which in some of its intentions reminds us of the cultural revolutions of Mao Zedong or Ayatollah Khomeini. The national revolutions were not as radical as those of the Maoists or Islamists, but they upheld a promise of a new culture. Georg Hegel's idea of the objectification of spirit is helpful in our attempt to understand the national movements of Central and Eastern Europe. Before reaching independence, the peoples of the region had to become self-conscious of their cultures.

In our attempt to understand the political experience of Central and Eastern Europe we should turn to Kahn's investigations of the relationship between revolution and constitution. We have to add the analysis of cultural revolutions. According to Kahn, "Revolution and constitutional construction mark the assertion of a power of the popular sovereign to destroy order by withdrawing the sovereign will and to create order by speaking it into existence" (Kahn, 2005, p.90). The constitutions of the United States and France came into being as a result of a revolutionary struggle for a new state. This pattern is foreign to the nations of Central and Eastern Europe, which did not directly engage in political revolutions but had to fight for their cultural identity. This struggle for cultural identity in the region was the necessary precondition for the appearance of the new states. The struggle for cultural identity carried by the national movements in Central and Eastern Europe from its very inception had been what Carl von Clausewitz described as doing politics by other means. Political aspirations always existed behind the demands for cultural identity. The national movements in the region had to go through the process of cultural revolution before 
they could become a political subject. These cultural revolutions were as demanding as political revolutions.

Kahn argues that in the concept of nation state the element of "state" is more important than that of the "nation." In his words, "The idea was that a nation could be created out of a state, not that state must track the preexistent nation" (Kahn, 2005, p.260). This thesis proves to be wrong if we consider the political experience of the states in Central and Eastern Europe. When the people in the region are discussing national matters, nation is understood as being a concept that belongs not only to the sphere of politics. Even when citizens of the region are engaged in discussions about political nation, they cannot avoid thinking in terms of culture. The French and American nations were born from political revolutions. In Central and Eastern Europe the nations had to prove their cultural maturity and only then could they go to the process of state building. The people in the region know that a nation can exist even when the political independence is lost. This viewpoint is accurately expressed by the Lithuanian philosopher Stasys Šalkauskis: "The revision of the territory of the state eventually is possible. The cultural strength of the nation and its relevance can become one of the deciding factors" (Šalkauskis, 1995, p.465). The cultural strength of the nation is understood as more important than state.

Manent thinks that at the time of its emergence, a nation state was the best tool for the creation of democratic politics. However, today the nation state is seen as being an obstacle to the processes of democratization. According to Manent, the dialectics by which a useful tool becomes an obstacle is unavoidable to all forms of political organization: "What allows us to reach an objective is also what prevents us from pursuing further the attainment of this same objective and even directs us in an opposite direction" (Manent, 2006, p.198). Manent wants to defend the nation state, but he misunderstands the very essence of this political form. Similarly to Kahn, he does not see the cultural side of the state. He thinks that the nation state is eliminated for political reasons. This is not a substantiated claim. The reason behind these changes can be found in the changes of the understanding of culture. The dialectics of a useful tool becoming an obstacle is also at work in the case of modern constitutionalism. The modern nation state is unthinkable without a constitution. However, contemporary constitutionalism is one of the most important driving forces in the struggle against the nation state. A number of attempts to create a constitution for the European Union are the most obvious example of this.

\subsection{The Nature of the Nation State}

The process that in France and the United States evolved into a change of forms of government in Central and Eastern Europe began as a struggle for cultural identity. The term national rebirth in this region has the meaning of cultural revolution. The goal of the national movements in the region was to create a new cultural subject that 
could later become a political sovereign. Only after the people who shared the same culture had been consolidated as a unique community could one begin to think of an independent state. When the names of nations capable of defending their own cultural identities became known, the names of the claimants for political sovereignty also became apparent. Many critics of nationalism are wrong to think that the epoch of national rebirth was a time when propaganda about the uniqueness of nations was being spread. These developments were also marked by important elements of cosmopolitanism. The more the nations of Central and Eastern Europe wanted to enjoy the fruits of the high culture, the more they became independent from parochial nationalism. The latter is usually understood as a conservative phenomenon. This interpretation does not reveal the whole truth. In its most important intentions nationalism is a revolutionary ideology. The contemporary detachment of constitution from the nation is one of the best proofs of this thesis. Constitution not only creates but also destroys the nation state.

National movements are being destroyed by the mode of thought that they generated. To be more precise, the fundamental premises of national movements today are working against nation states. The forces that created the cultural revolutions are the forces that today are working against the achievements of that revolution. Once again, the revolution is devouring its own children. The premises of the nation state become a weapon in the struggle against the nation state. There are at least three causes behind this self-destruction. Firstly, the phenomenon of multiculturalism is a consistent development of the political ideas of nationalism and this offspring undermines the power of nationalism. National movements begin with a demand to recognize their cultural uniqueness. Once they gain success and the statehood is achieved, it becomes clear that nation is not the ultimate indivisible element of cultural identity. The final point of this process of division is the individual. Just as nations demanded to be recognized, today recognition is demanded by feminists, sexual minorities, and other cultural groups. Secondly, national movements cannot withstand the corrosive effects of historicism. When everything is thought to be historical, the nation must be interpreted as something that undergoes permanent changes. Because of historicism the political metaphysics of nation today has lost its power. Thirdly, national movements are being destroyed by the passion that they themselves had unleashed the passion to modernize. The aim of modernization transforms itself into an aimless quest of novelty for novelty's sake. The unceasing search for novelty leads to the situation when people no longer see their nation as the basis of political life. This development necessarily leaves its mark on constitutionalism. Constitutionalists pay little attention to the political history. Their views are focused on the future.

During the first stage of their formations the democracies needed a demos and nation was chosen as the new demos. Nation building in Central and Eastern Europe was seen as being more important than the creation of constitution. Nations had to identify their own cultural constitution and only then could they create political constitutions. We can only understand the traditions of constitutionalism in Central and 
Eastern Europe only after we have understood the historical process by which the nations of the region became sovereign. This is why we have to pay serious attention to the political and cultural history of the region. The thesis that nation became sovereign says too little. We must know how specific nations formed their cultural identity. The road to constitutionalism in Central and Eastern Europe is very different from that which was taken by the Western nations. For the newly formed nation states in the region the establishment of constitution was only one task among many others in their attempts to create a new political order. This problem was usually solved by taking the principles and norms from the constitutions of Western liberal democracies.

The nations of Central and Eastern Europe, especially the small ones, live by the faith that even if they lose political independence, they can continue to exist by protecting their cultural identity. The historical experience of this region does not allow one to fully grasp the politics of the region without taking into account the cultural dimension. Any discussion about politics here must involve discussions about culture. For two centuries the understanding of the nation state in Central and Eastern Europe has been firmly coalesced with the notion of national culture. The idea of the nation state in the region demands that political and cultural questions go hand in hand. If there were no cultural differences between the citizens from various states in the region, the understanding of the significance of political independence would not exist. Nation state in the region is seen as a twofold phenomenon wherein universal principles of constitution must be harmonized with the national culture, which by its very essence is particularistic.

Because of the historical experience of aggressive nationalistic regimes, the discussions about the nation state in Central and Eastern Europe has become an uncomfortable topic. The twofold nature of the nation state makes moderation very difficult. There is always a danger of a drift toward radical politics. When people begin to put too much importance on their national culture, universal legal principles can be thrown overboard. When too much emphasis is put on universal principles, the task of upholding the national culture is forgotten. The twofold nature of the nation state means that statesmen and citizens must find a delicate balance between their unique culture and constitutionalism. One could not deny that universal principles of law are a crucial element of political life. However, according to the traditional understanding of the nation state in Central and Eastern Europe, these principles have to be harmonized with the task of upholding the unique cultural identity. When the importance of the cultural dimension of the nation state is forgotten and all emphasis is placed on the universal principles of constitution, democracy or social welfare, the very idea of the nation state loses its function and meaning. Even when taking a critical stance towards nationalism, we have to admit that the states in Central and Eastern Europe are unimaginable without the element of a nation. When the importance of the nation is forgotten, the meaning of political responsibility disappears. National identity in the region is traditionally seen as a necessary element of politics. 
This is why any attempt to grasp the peculiarities of constitutionalism in the region cannot allow itself to lose sight of the importance of cultural matters.

The kind of liberalism espoused by John Rawls, which demands a clear separation of culture and politics, is completely unsuitable to the traditions and realities of Central and Eastern Europe (Rawls, 1996). The people of the region do not ask whether a sovereign and independent state is a meaningful political form. Most of them do not doubt this. The most important point of the problem is whether the contemporary culture can justify the struggles of previous generations for political independence. This question is not about the freedom of the individual but about the meaning of the existence of political and cultural community. Many philosophers designate this problem by the name of positive liberty. No one could seriously doubt that constitutional principles are a key part of politics in Central and Eastern Europe. However, because of the understanding of the nation state in the region, they have to be harmonized with the goals of upholding national culture.

\subsection{The Conflict between Nation and Constitution}

The conflict between the two main elements of the nation state, culture and politics, remains a permanent threat. It is not easy to say what role constitutionalism plays in this conflict. It can be attributed to both politics and culture. The answer to the question depends on the convictions held by the person. If we highlight only the political dimension of constitution we will fail to understand that it can be used not only as a tool to express the will of the nation but also as a tool to suppress it. Constitutional law cannot evade the conflict that is to be found in the very nature of the nation state, the conflict between culture and politics. Even though the sovereign in Central and Eastern Europe emerged from the historical changes in cultural matters at a certain time the functioning of the constitution becomes independent from the national culture. The reason behind this development is that liberal democracies tend to operate with the notion that the law is sovereign. The conflict between these two understandings of sovereignty becomes inevitable. Carl Schmitt has shown that the liberal idea of the "sovereignty of law" is by its very nature opposed to the democratic idea of the "sovereignty of nation." In his words, "A logically consistent and complete Rechtsstaat aspires to suppress the political concept of law, in order to set a "sovereignty of the law" in the place of a concrete existing sovereignty" (Schmitt, 2008, p.187). From the very beginnings, the concept of nation state has contained an element that is hostile towards the nation. The experience of the European Union shows that it is possible to create a constitution without a nation.

The idea of constitutional patriotism proposed by Jürgen Habermas and other philosophers is the best example how constitution is capable of transcending the nation and nationalism. According to the advocates of constitutional patriotism, loyalty to the constitution can overcome loyalty to the nation. In the words of Habermas, 
“The political culture of a country crystallizes around its constitution. Each national culture develops a distinctive interpretation of these constitutional principles that are equally embodied in other republican constitutions - such as a popular sovereignty and human rights - in the light of its own national history" (Habermas, 1998, p.118). Nation is understood as being of less importance than constitution. Nation and its cultural particularities disappear from the political and legal thought. The advocates of constitutional patriotism operate solely with the concept of political nation. The jurists of a political nation recognize the universal norms of the constitution and their ethnicity is of no relevance. This line of thought sees constitution as a tool for neutralizing the political importance of national cultures. The aim is to make citizens patriots of constitution. Patriotism remains, but it becomes completely foreign to the patriotism from the times of national rebirth. Identification with nation is seen as being a purely private choice. Constitutional identity and political notion of the individual become the basis of political life.

Once the independence had been established, the nations of Central and Eastern Europe embraced the universal constitutional principles. However, nation as a political sovereign has its own unique culture and history. A tension between universalism and particularism has to necessarily exist in a nation state. Particular cultural identity of nation comes into conflict with universal cosmopolitan legal norms. When Central and Eastern European nations became members of the European Union, universal legal norms became more important than national sovereignty. Viewed historically, the nations of the region first had to become self-conscious of their uniqueness and only then could they hope to reach statehood. Today we see a movement from the sovereignty of the nation to the sovereignty of law. This means that a nation state is incapable of fulfilling its cultural promise. Cosmopolitan legal principles and norms are in direct opposition with the old cultural promises of national movements. Constitution becomes detached from the sovereign who had created it in the first place. At the end of the 19th century and during the first part of the 20th century modern nations of Central and Eastern Europe wanted to become constitutional republics. Today constitutionalism has become opposed to the very force that made it possible.

The idea of constitutional patriotism allows us to see the modern nation state in a new light. It becomes clear that this state cannot fulfil its cultural promises. Cultural education has been pushed out to the sphere of private choice. Advocates of constitutional patriotism think that jurisprudence has its own method for deduction of norms. There is no place for cultural matters in this method. Moral and cultural disagreements between citizens are seen as a source of political disagreements and this is the reason why they are driven out to the realm of private sphere. Citizens of liberal societies who cannot agree on questions of morality and culture have to agree at least on their constitution. Culture is said to belong to Lebenswelt and legal norms to the sphere of Rechtsstaat. Liberalism comes into conflict with the historical experience of the nation states. Constitutions in Central and Eastern Europe were born from cultural struggles. According to the understanding of state that was dominant 
in the political thought of the region, the goal of political independence is not only to protect human rights but also to protect cultural identity. The concept of a nation state can disappear from the political vocabulary only when the understanding of uniqueness of the culture is forgotten or seen as being politically irrelevant.

The nation state stands or falls by what Alexis de Tocqueville described as the method of democracy. Scholars tend to miss the crucial importance of the chapter "Of the Philosophical Method of the Americans" in his Democracy in America. Here Tocqueville claims that even though Americans do not read Descartes, they think according to his method (Tocqueville 2010, pp.698-709). This observation allows us to gain a better understanding of the nation state. This state came into being as a democratic form of political life but it remains a hostage of the Cartesian method. If we follow the philosophy of Descartes we cannot prove the necessity of the nation state. National movements brought about the permanent aspirations for more and more liberty and these aspirations have become hostile to the ideals of national movements. The proponents of the Cartesian method have no feelings of loyalty to any culture. For them self-evident cultural identities do not exist. When national movements began, the Cartesian method was seen as a useful tool. Today it has become hostile to the very ideals put forward by those movements. A nation state is a product of modern democratic thought and for this reason it is destined to fail. Those states cannot be protected from the corrosive influence of the method, which once helped to form them in the very first place. As a result, there is no reason to think that constitutionalism can be protected from this method.

Citizens of Central and Eastern Europe are proud of their democratic constitutions. However, at a certain point these constitutions begin to take away the sovereignty from the nation. The nations of the region understand the importance of constitutionalism, but they do not share the American and French experience of establishing constitutions. In their history cultural identity is of more importance than constitutionalism. For the citizens in the region, constitution is only one of many documents that establish the statehood. Kahn's explanation is somewhat Aristotelian. For him, political revolution is the moving cause, constitution - the formal, whereas citizens' identification with the constitution is regarded as the material cause. This Aristotelian line of thought must be modified to explain the politics of Central and Eastern Europe. Here the moving cause was not a political revolution but cultural identity. Constitutional experts do not pay enough attention to this difference. Kahn's thesis that "final cause of the nation state is nothing more than the perpetuation of the state's own existence" (Kahn, 2005, p.276) is foreign to the realities of Central and Eastern Europe. The initial goals of the nations were connected by culture. We cannot agree with Kahn's idea that nation states had only political aims. Central and Eastern European states came into being with the promise of a new culture.

Two different revolutions took place in Central and Eastern Europe - cultural and political. The first one had to do with the building of new nations, the second with the building of states. Today we are witnessing a third revolution, which can even 
be called a counter-revolution, the nation state is being pushed away from political life. These three revolutions are the effects of what Tocqueville called the "method of democracy". The philosophical presuppositions of the nation state make its failure inevitable. It is incapable of withstanding radical cultural changes. The method that played such an important role in the creation of a nation state today has become its executioner. Democracy is destroying its own creations. The same process occurs during the rise and fall of a nation state. From its very beginning a nation state was based on presuppositions that do not allow its citizens to achieve their goals. One democratic revolution follows another democratic revolution. We have no reason to think that constitutional patriotism can be more durable and stronger than the national one.

Citizens of nation states like to think that the rule of law is possible. Constitution and law are seen as something that can supersede politics. The attempt to do away with the nation state goes hand in hand with the attempt to do away with politics or at least to reduce it to law, economy or humanitarian morality. According to Schmitt, the driving force behind this belief is the political philosophy of liberalism: "The principles of the modern, bourgeois-Rechtsstaat constitution correspond to the constitutional ideal of bourgeois individualism so much, indeed, that these principles are often equated with the constitution as such and "constitutional state" is given the same meaning as the "bourgeois Rechtsstaat" (Schmitt, 2008, p.169). Yet this explanation is incomplete. Liberals could never overcome the nation state on their own. The changes in Western culture make the achievement of this aim much easier. The changes in moral self-consciousness of the citizens are important factors that promote the indifference towards the nation state. The individual is understood as being superior to community, personal good is more important than the common good, universality triumphs over locality. The nation state had a firm moral basis that today is becoming less and less significant.

The political freedom of a nation is superseded by liberty from the nation. Manent is right when he states that "today common European opinion indeed considers humanity as the only available resource and reference point now that the nations are exhausted" (Manent, 2013, p.326). However, the causes behind this development are not the ones that he proffers. Manent is mistaken when he claims that nation state is only a political form. Nation states in Central and Eastern Europe are unimaginable without a struggle for cultural identity. This fact makes this form of political organization extremely vulnerable to the changes in cultural attitudes. Important cultural developments produce significant changes in the understanding of the nation state. The less the nation understands its own cultural uniqueness, the less significant the independence of the nation state becomes. Without the appreciation of cultural differences the discussions about nation state lose their meaning. According to Kahn, "legal rules do not come from nowhere. We read in every legal regulation a narrative of the state's self - creation” (Kahn, 2005, p.271). A constitutional system can hardly 
be created on the basis of universal principles. The recognition of local culture is of paramount importance.

Schmitt specifies three different types of juristic thought - normativism, decisionism and concrete-order. "Every jurist who consciously bases his work on the concept of Recht, concieves of this Recht either as a rule or as a decision, or as a concrete order and formation (Gestaltung)" (Schmitt 2004, p.45). This classification helps us understand the relationship between nation state and constitutionalism. During the formation of nation states it was thought that the most important thing is the political decision of the nation. This type of juristic thought is being displaced by pure normativism. Cultural order is being superseded by the order of legal norms. And there is a conflict between these two lines of thought. Normativists think that law is just a collection of norms and can be understood without any reference to history and culture. This mode of thinking is of great importance when discussing the traditions of legal thought in Central and Eastern Europe. The states in the region began from a certain cultural order, but today they seem to have no need for it. National patriotism, as noted, gives way to constitutional patriotism. The fundamental presuppositions of the European Union are opposed to the presuppositions that allowed the nation states of Central and Eastern Europe to emerge. Constitution is seen as a more important thing than the sovereign that created it. As a result the interpreters of constitutions today tend not to pay attention to the cultural differences and the different roads by which nations reached their independence. Experts of constitutional law from Central and Eastern Europe discuss with their colleagues from the West and in these discussions there is no place for differences of culture. Kahn is right to point out that experts of constitutional law tend to forget the revolutions, from which these constitutions emerged. Constitutional experts from various member states of the European Union meet in the space of pure juristic normativism.

The rule of law in the European Union has become more important than the nation, which is the source of legal order. Schmitt had described similar process as a conflict between bourgeois Rechtsstaat and national sovereignty: "The aspiration of the bourgeois Rechtsstaat, however, is to repress the political to limit all expressions of state life through a series of normative frameworks, and to transform all state activity into competencies, which are jurisdictions that are precisely defined and, in principle, limited" (Schmitt, 2008, p.93). Advocates of Rechtsstaat think that the rule of law can become sovereign. During the last two centuries, the nation state was protector of human rights. Today we see how the human rights can be protected without the nation state. During the times of national rebirth democracy needed the nation as a subject that would defend the human rights. Today citizens of democratic societies and experts of constitutional law think that the nation has no role left to play in politics. This marks the emancipation of democracy form the nation and points towards the creation of a cosmopolitan empire of law. It is the rule of law without the nation: "The sovereign law replaces the sovereign who determines the law" (Manent, 
2006, p.174). Constitution is understood as being more important than politics, selfgovernment and cultural identity.

The historical experience of Central and Eastern Europe shows that a nation state is a contradictory phenomenon. It comes into being and seems to be destroyed by the same method, which Tocqueville had described as the "method of democracy." The cultural identity in which nation states emerged is sharply different from the contemporary one. Tocqueville wrote that "a great democratic revolution is taking place among us" (Tocqueville, 2010, p.80). We can add that a nation state is a central component of this revolution. One of the most important characteristics of the democratic revolution is the permanent reevaluation of its own achievements. Nation states began with the struggle for cultural identity. Today we see how this struggle has transformed itself into attempts to eliminate national culture. Many believe and even try to prove that constitution can take over the title of sovereignty from the nation. Viewed from the perspective of Central and Eastern Europe this looks like a highly unconvincing undertaking. When we discuss constitutional matters in this region we have to pay attention to the cultural self-consciuosness of the people who represent the source of the constitution. From what has been said it does not follow that a constitution can be established only by an ethnic nation. However, it is impossible to have a constitution without a political subject. This is why the enthusiasm of constitutionalists to do away with the nation state raises doubts.

\section{Bibliography}

Habermas, J. (1998). The Inclusion of the Other. Studies in Political Theory. Cambridge, Massachusetts: The MIT Press.

Kahn, P. (2005). Putting Liberalism in Its Place. Princeton and Oxford: Princeton University Press.

Kahn, P. (2011). Political Theology. Four New Chapters on the Concept of Sovereignity. New York: Columbia University Press.

Kohn, H. (1967). The Idea of Nationalism. New York: Collier.

Manent, P. (2006). World beyond Politics. A Defence of the Nation State. Trans. M. LePain. Princeton and Oxford: Princeton University Press.

Manent, P. (2013). Metamorphoses of the City. On the Western Dynamic. Trans. M. LePain. Cambridge, Massachustts; London, England: Harvard University Press.

Rawls, J. (1996). Political Liberalism. New York: Columbia University Press.

Schmitt, C. (2004). On the Three Types of Juristic Thought. Trans. J. W. Bendersky. Westport, Connecticut, London: Praeger.

Schmitt, C. (2008), Constitutional Theory.Trans. J. Seitzer. Durham and London: Duke University Press.

Šalkauskis, S. (1995). Raštai. Vol. 4. Vilnius: Mintis.

Tocqueville, A. (2010). Democracy in America. Historical-Critical Edition of De la démocratie en Amérique. Trans. J. T. Schleifer. Indianopolis: Liberty Fund. 
Waldemar A. Skrobacki ${ }^{1}$

\section{Remarks on the Legal and the Practical:}

\section{The Rechtsstaat in Europe's Development of the Rule of Law}

Rechtsstaat, l'État de droit, Pravovoe Gosudarstvo, from Germany to France to Russia, these are terms that refer to the role of law, its nature and political utility in the process of governance. The theoretical interest in the concepts that stand behind the terms, such as accountable government, has an intellectually rich tradition. Because they originated in Europe and because of the continent's impact on the world, they have been also geographically universalized from Indonesia to Burundi, for example (Bossuyt et al. 2013; Qamar, 2013).

Although the interest in law and its role has a long history, it was re-energized and re-informed by the demise of feudalism in Europe. Feudal society was the common experience of all Europeans. Its main characteristics were collective identity, disregard for individuality and the personalized rule of the feudal landlord. He shaped the identity of the household, set the rules upon which it functioned and decided about the lives of its members. His wishes provided the foundation for the household's laws. Consequently, the legal could be changed at will. Personalized rule also meant personalized politics: the landlord exercised power in a direct way, including meting out justice. Therefore, he was free to use whatever means of power he wished to utilize.

Moving away from feudalism required institutionalized politics. Thus, the will of the ruler needed to be replaced by institutionalized rules of governance. Consequently, this replacement was changing the role of law, for it became a chief factor of the institutionalization of politics. This new role of law was further enhanced by the growing size of the areas of jurisdiction. The households, be it by force or agreement, were combined into a much bigger space, for example, principality, the size of which made it impossible to rule over it in a direct and personal way. The prince needed a set of rules that had to be obeyed by his subjects and a set of institutions that could implement them. This eventually led to the creation of the modern state; and because the end of feudalism was gradual and uneven, various types of states emerged. This process was also prolonged.

For example, the Icelandic Althingi was set up in 930. The Russian Duma was established in 1906. The Magna Carta in 1215 severely limited the power of the monarch, which eventually would be almost entirely transferred to the parliament. In Russia, by contrast, the last tsar Nicholas II was still declaring his devotion to autocracy.

1 The Jagiellonian University in Kraków. 
Furthermore, the movement away from feudalism was a multifaceted process. One of the most important factors was the asymmetrical shift from collectivism to individualism. The asymmetry derived from the interplay of the individualism of political freedoms and the collectivism of feudal society. The former eventually were institutionalized in the form of rights that ushered in constitutionalism. The latter morphed into nationhood, the modern form of collectivism, which would be built into the state in the form of the welfare state dispensing public goods. As a result, the paternalism of the feudal household and the individualism of constitutional rule became interconnected. The interconnectedness, however, was not necessarily between two equal parts. In some states, there was more paternalism than individualism. In some other states, it was the other way around.

In Britain, the interconnectedness became strongly tilted towards individualism. The Magna Carta was the first step. What followed was a long process of limiting the ruler's powers. The limitations became a list of do's and don'ts the royal had to obey. Over the centuries, the list has become a combination of both written and unwritten measures that eventually led to a parliamentary rule and accountable government. The monarch became merely a symbol of the state's authority with the task of protecting its stability in case of a constitutional crisis.

The very fact that some constitutional limitations imposed on the power holder are unwritten well illustrates the utility of law in the British tradition of individualism. The main aspect of the utility is the very nature of law, for it is not simply to prohibit and punish but, instead, to nurture individualism and protect the rights of individuals. Therefore, the spirit of law is civic-mindedness and citizenship. As an English colonel put it, “... I do think that the poorest man in England is not at all bound in a strict sense to that government that he has not had a voice to put himself under... " (quoted in Heater, 2004, p.63).

Still more, spirit does not necessarily require letters; but it does necessitate its proper comprehension, which becomes a form of guidance to civic attitude and behavior and, in the end, community of free individuals. Law exists to govern people, for they are not to be governed by arbitrary decisions of power holders. As such, the role of law became the rule of law. Subsequently, the legal was to protect the freedom and the practical was to protect the legal.

With such a strong emphasis on individualism, it is not surprising that pubic goods came only after the rule of law had been firmly entrenched in society. The first step towards the welfare state was the 1942 Beveridge Report on Social Insurance and Allied Services (Beveridge, 1944). By then, all segments of British society had the rights acknowledged and protected. In fact, being British meant having rights as an individual.

The role of law in continental Europe was not a duplication of the British approach. The French case of the interconnectedness was more balanced, for paternalism was not de-emphasized. The 1789 Revolution introduced the notion of Le Citoyen. She was now to be free, but she was also not to be hungry. The clarion call of the revolution 
- liberté, égalité and fraternité - reflected the more balanced approach to rights and goods. Liberté was about rights. In this sense, the French revolution was similar to the British tradition of individualism. However, fraternité was about goods. The link between the two was égalité, especially for the third estate. Thus, while stressing the rights - the Declaration of the Rights of Man and of the Citizen - the idea of the delivery of public goods by power holders was not rejected. This is why the declaration included several articles on taxes. This stood in contrast with the Magna Carta, which was about reducing taxes or not paying them at all (Vincent, 2012).

The combination of goods and rights was put in the context of nationhood (collectivism) and national citizenship (individualism). Thus, being French meant being both free and provided with public goods; and the citizen was entitled to both, for he was French. The legal was to maintain Frenchness. The practical was to shelter and reinforce the legal. The role of law became the l'État de droit.

In Germany, the interconnectedness was similar to the British tradition, for it was equally unbalanced. This was also the chief difference, for in the German context the stress was put mainly on collectivism. Similarly to the French experience, the goods were put in the context of nationality. When Germany was unified by Bismarck in 1871, its people were late with their formation of nationhood. Most Europeans had already developed their national identity. Being late was making the unification ever more difficult to accomplish. The main difficulty was the millennium of conflicts and shifting alliances among the German principalities.

Unifying them into one state, the Second Reich, required a means that would be acceptable to all members of the First Reich. The common unifying factor were public goods, for they had a long history in the German lands, going back to the medieval times (Knox, 1993; Radich n.d.). Now Bismarck had to put them in the context of unification.

In 1883, he passed the Workers' Health Insurance Act, followed by the 1884 Industrial Accident Insurance Act and the 1889 Invalidity and Old-age Insurance Act. These schemes were national and constituted a system of national solidarity. They were designed for a collective, the German nationals, rather than for an individual. Thus, being German meant being entitled to them because one was a member of the German nation. Consequently, the welfare state became a means of nation building; and this was a task for the unified German state. To do so, the state had to have a tool for fulfilling the task. The social insurance acts required various regulations for implementation. Since the new German state passed the acts, it was also its role to issue the regulations and to execute them. Fulfilling the task became the primary role of law.

Bismarck could not solely use force to unify the Germans. Force is not an effective tool for identity formation. Nevertheless, he had to impose uniformity to eliminate the centuries-long regional divisions. The matter of creating national identity became a social question (James, 2000, p.63). The question was to be dealt with by the state providing public goods and doing so through law. However, unlike in Britain and France, 
the law sought to instill collectivism at the expense of individualism and the rights that came with it. Hence, the legal was to promote Germaneness through social solidarity, which became an important part of the firming up of German nationalism. The practical was to serve the legal. The problem was how this should be effected.

Before the unification, the goods were dispersed at the regional level. Although state institutions of a principality were delivering them, this was done on behalf of the regional ruler. Therefore, the goods and the delivery mechanism were in a way an extension of personalized politics and rule carried over from the feudal household to modern times. Moreover, the regional leaders represented tradition, which for many ruling dynasties became a foundation for their legitimacy. By contrast, the goods and delivery coming from the newly created state lacked the tradition, authority and respect of the regional leaders. These lacking elements had to be put in place. In a speech to the Reichstag on May 9, 1884, Bismarck said,

\footnotetext{
Give the working man the right to work as long as he is healthy; assure him care when he is sick; assure him maintenance when he is old. ... [I]f the State will show a little more Christian solicitude for the working man, then I believe that the gentlemen of the Wyden [Socialist] programme will sound their bird-call in vain, and that the thronging to them will cease as soon as working men see the Government and legislative bodies are earnestly concerned for their welfare (quoted in Krueger, 2000, p.118).
}

The paternalism of feudalism was recreated with all its characteristics. The Germans were to be provided again by the power holder, for the new government was just as caring as were the regional rulers. However, since Bismarck's government did not have the patina of tradition, he had to modify the main elements of the tradition and move them to the national level.

First, because there was no dynasty that could support political stability, the methods of exercising power had to be adjusted accordingly. In the feudal household, the landlord could jump on a horse, move around the domain and point with his hand which way a new road was to be built. Now, to do the same, the hand had to be reinvented.

Second, the pointing needed to be realigned to reflect the changed settings of power: for example, the large size of the unified Germany; industrialization and its impact on stability, such as the workers' movement; or the need to deal with matters related to development. The realignment was necessary for the new government to be efficient. Only then, was there a chance for the new hand to be effective and eventually legitimate. To accomplish that, Bismarck converted the authority of a German prince to the authority of the German state by modernizing the institutions of the latter and keeping the traditional character of the former. This was done by employing state regulation.

For instance, to administer the 1884 insurance act, he set up the Arbeitgeberverband in den beruflichen Korporationen, a bureaucracy responsible for a centrally managed system of payments for medical treatments and compensation monies to 
accident victims. By 1886 the insurance covered agricultural workers. Thus, carrying over feudal authority in a modernized form, the central government become the sole provider of the benefits in a manner of a feudal ruler.

Of course, such a system required rules of operation. To manage the payment system, both the government and, upon instruction, the Arbeitgeberverband, could and did issue seemingly endless regulations clogged with detail. This was the government's modern hand that was pointing out the direction of this and any other policy. Thus, the Rechtsstaat was put into practice, the kind of state that was feudal in spirt and origin, but modern in form and method. Its authority remained essentially unchanged, as it was still imposing its will on the population without public consultation; and it continued to be the essential center of decision making. Just like in the Middle Ages, the center was able to shape to a significant degree the lives of the people who remained subjects, even if modernized. Therefore, instead of jumping on a horse to manage the household, the chancellor used regulation to manage the Germans. Law became the modern form and method; but the execution of power retained its feudal character. The sternness of the landlord's rule was now reflected in the legalism of the Rechtsstaat. Consequently, the nature of regulation also retained its feudal features: it was prohibitive, controlling and collectivist.

Without individualism and rights, such as the rule of law or the l'Etat de droit, the Rechtsstaat was a modernizing factor, but it was not a tool of modernity. It became such a tool when the Rechtsstaat was supplemented and enhanced by Rechtsstaatlichkeit - rule of law-ism - which was introduced to the Germans after the Second World War. It was also tailored to the country's Rechtsstaat. It kept it in place; but added to it individualism and, hence, rights and, in general, the principles of liberal democracy.

From the perspective of a formal understanding, the term Rechtsstaat describes the type of state architecture and political order system in which all publicly applied power is created by the law and is obliged to its regulations and underlies numerous fragmentations of power and control mechanisms ("Bindung und Kontrolle"). Rechtsstaatlichkeit in this sense is a collective term for numerous (sub-)principles that allow the taming of politics by the law and shall avoid arbitrariness. From the perspective of a more substantive understanding, Rechtsstaatlichkeit also expresses democratic concerns and the respect to individual human freedom and equality and thus the commitment to a liberal and just constitutional order (Koetter, 2013).

This is why now "... many European writers ... use the term 'rule of law' when they write in English about 'Rechtsstaatlichkeit'.” (Silkenat et al. 2014, p.93).

The critical additions were the mechanisms and principles that were to tame both the usage of legalism and the legalism itself, for the former was allowing arbitrariness and the latter was a tool of arbitrariness. The process of adding individualism and rights, however, was neither straightforward nor quick. After all, it required an outside intervention. After the defeat in 1945, the Germans were required to change fundamentally the state, its operations, and their attitudes towards it. In short, they 
were required not only to modernize themselves, but, first and foremost, become modern.

Max Weber, while trying to figure out what makes society change in a profound way, for instance, by switching from authoritarianism to democracy, identified several factors of societal change, such as, the religious attitudes of the Protestants, the stock exchange or, indeed, the role of law. However, he concluded that the factor that contributed the most to the change was the prevailing type of authority. According to Weber, there are three ideal types of it: traditional, legal, and charismatic. (Weber, 1947, pp.324-423) The traditional type is based on deeply rooted principles of governing. As long as the ruler observes them, he is legitimate and, hence, is to be followed. In this type of authority, the relationship between the ruler and the ruled does not have to be institutionalized.

Legal authority rests on regulations created by law and is exercised only in accordance with them. Everyone is supposed to follow the regulations, including those who hold power. Here, the relationship is institutionalized and impersonalized. The charismatic type rests on the assumed and accepted extraordinary qualities of the power holder:

... a certain quality of an individual personality by virtue of which he is set apart from ordinary men and treated as endowed with supernatural, superhuman, or at least specifically exceptional powers or qualities. These are ... not accessible to the ordinary person, but are regarded as of divine origin or as exemplary, and on the basis of them the individual concerned is treated as a leader (Weber, 1947, pp.358-59).

This relationship can be institutionalized, but does not necessarily have to be. The three types are mixed in real life. The combination of the traditional and charismatic types is usually a feature of pre-modern societies. A mixture of traditional and legal types is a characteristic of modernity. The transition from pre-modernity to modernity is tantamount to changing the prevailing type of authority in society. The change may bring structural alterations, and it usually does. But the transition always changes societal values. For instance, moving from feudalism to capitalism brought about entrepreneurship and societal individuation, for such is the Geist des Kapitalismus (Weber, 1947, pp.91-92; 2003, pp.47-78).

The Geist of the Rechtsstaat, despite its formal "mechanics" of modernity, was not a factor that would bring about the change of the prevailing type of authority. This was quite ironic, for Kant with his ideal of negative freedom is usually thought of to be the one who inspired the very notion of the Rechtsstaat (Strauss and Cropsey, 1987, pp.581-82). Thus, the state, to be lawful, that is, legitimate, must be a union of people governed by reason protecting freedom and individualism. The state is not to inhibit the people's freedom, for it is the gist of limited government. This, no doubt, was an importation of the rule of law. However, because it came from outside, it was quite strange and not necessarily appreciated by the Germans at large. Not surprisingly, the Kantian importation was relatively quickly tailored to the German tradition. 
The term Rechtsstaat was coined in 1798 by Johan Wilhelm Placidus and popularized by Robert von Mohl in 1844 (Silkenat et al. 2014, p.296). However, while popularizing it, von Mohl moved from negative freedom to positive freedom. Instead of protecting freedom and individual rights, the state became the giver of them. Since the state was to be law-based, or Rechtsstaat, it retained to a degree its Kantian idea. Consequently, it was still suitable for the tasks assigned to the state by Kant. It was just a change of how the state was to do it, not what it was to do and why.

However, the change of the how meant that Kant did not succeed, but von Mohl did. The Germanization of the Anglo-Saxon rule of law, for the Americans had become a party to it by then, worked quite well. Since the Germans were only starting their acquaintance with the principles and practice of liberal democracy, it was not surprising that the Rechtsstaat became a modernized extension of feudal rule in the end.

To be sure, Germany was not an exception in Europe at the time. Russia, for example, was not much different. In fact, Russia is still not much different. The Duma of the beginning of the twentieth century was an attempt to introduce the rule of law to Russia. However, the introduction was not successful. Similarly to the Rechtsstaat, the Russian Pravovoe Gosudarstvo also became an extension of feudal rule. Unlike in Germany, Russia did not have a Kant of its own. Hence, the introduction of the rule was Russified right from the beginning.

The Decembrist uprising of 1825 marks the intensification of the struggle for the constitution in Russia. Decembrist thinking, however, is highly ambivalent and contradictory, with the Southern Society represented by Pavel Pestel favouring a strong but republican state to achieve the aim of modernisation, while the Northern Society's views on constitutionalism were more liberal and federalist while at the same time monarchist (Sakwa, 1996, p.115).

Thus, the choice was between a republic with a strong president endowed with powers similar to the absolutist rule of a king or a monarchy with a sovereign, perhaps gentle, yet still entirely in charge of the rights of the people who were to stay subjects rather than become citizens. This was not much of a choice, for both Societies were assuming that the state was the giver of rights rather than a protector of them. This put the Decembrists in direct opposition to the rule of law, even though they were demanding constitutionalism in Russia. The prevailing type of authority was not to be changed. The ruler, be it president or king, was to remain extraordinarily powerful, perhaps because only an extraordinary person, a charismatic figure, could have so much power. Paradoxically or not, the demands for constitutionalism, however understood, was the revolutionary part of the Decembrists, for in Russia constitutionalism was deemed to be incompatible with the country's political culture (Walicki, 1987, pp.15-16).

The incompatibility was reflected in the Dumas. Those who were instrumental for setting up the bodies did not care much about them. The first two Dumas lasted less than 200 days, despite being dominated by the Kadets, who were supposed to be liberal and western. The third and fourth Dumas lasted five years each, and, while 
lasting, they engaged in passing thousands of bills, thus pursuing legalism similar to that of the Rechtsstaat (Jackson and Devlin, 1989). The difference was the fact that while the German parliament operated in a state that was becoming increasingly stronger, the Russian Dumas were passing the many bills in a country that was becoming steadily ungovernable.

The relationship between the legalism of the Dumas and the weakening of the state was only confirming the notion that the ruler must be strong. Consequently, law in Russia could only work if it was one of the tools of the ruler. If law was used by something or somebody else other than the power holder, it was pretty much useless, which is why it did not stop the decay of the czardom. This was the chief difference between the Pravovoe Gosudarstvo, which was stressing the power of the ruler, and the Rechtsstaat, which emphasizedg the strength of the state.

Consequently, the Rechtsstaat had the potential of moving German society from one based on the charismatic-traditional type of authority to the traditional-legal type. Thus, when coupled with Rechtsstaatlichkeit, the original legalism of the Rechtsstaat could be transformed into a foundation of a rule-of-law regime that requires a more detailed form of governance, often referred to as judicialization of politics (Blair, 1978), to protect the freedom and rights of the citizens. Thus, the state, and this remains the case in contemporary Germany, still relies on regulation, but now it is used to protect the freedom and rights of the citizens, not to rule over the subjects.

However, the Pravovoe Gosudarstvo, a term and concept that appeared in the latter part of the nineteenth century (Sakwa, 1996, p.116), had no such potential, for it still rested on the idea that power belonged to the Batushka, an extraordinary and paternalistic leader who holds it to protect and promote the well-being of Russia. Any institutionalization of power, such as the Dumas, went against the grain of Russia, therefore. No wonder, then, that the next attempt at using law as an instrument of modernization would only come in the late 1980s Soviet Union.

The constitutions in the Soviet Union had chiefly a propaganda role to play, just to show that the USSR was as democratic as any western state was. The exception of sorts was the 1918 constitution, for it, at least in theory, introduced federalism based on nationality. Had the federalism been indeed implemented, the Soviet Union would have been a very different state, most likely. But then again, the reason for the failure of Soviet federalism was the prevailing type of authority. Federalism requires sharing of power. This calls for a scheme of sharing that is institutionalized somehow, usually by the constitution. However, how can power be shared if the holder of it has, or is supposed to have, extraordinary qualities? Charisma, however based, cannot be shared.

The Pravovoe Gosudarstvo was included in the 1993 constitution of the Russian Federation. However, the term was revived during the Gorbachev period. At that time, rights of individuals and groups in relation to the state were looked at as something that was to be respected and weaknesses in the law were to be fixed. (Barry, 1992, 
pp.xii-xiv). By the middle of the 1990s, the weaknesses should have been fixed, one could presume.

On the surface, the reforms seem impressive. An enormous number of laws have been drafted with the assistance of Western experts. Many have gone on to become law, either through the legislative process or via Presidential decree. ... Given this [Soviet] legacy, merely passing new laws and revitalizing legal institutions is not sufficient. If these reforms are to be meaningful, they have to aspire to more; namely, to reshaping basic societal attitudes toward law. Absent attitudinal changes-that is changes in the underlying legal culture-even the best laws (from a technical point of view) will lie dormant (Hendley, 1996, pp.238-39).

Societal change can come either from above, which was the case in England or Germany, or from below, for example, France. Either way, there has to be a force determined to introduce reforms in a serious and profound way. So far, Russia has been lacking such a force. That is why the Pravovoe Gosudarstvo remains what the Rechtsstaat was before it was supplemented by Rechtsstaatlichkeit. In Russia, however, the pre-modern type of authority continues to prevail. And as long as it does, law will be a tool in the hands of the leader. Thus, the legal is to serve the ruler and the practical is to observe the law and, hence, serve the ruler. This is the nature of the Pravovoe Gosudarstvo.

Steven Blank makes a good point:

Western failure to understand the crucial role that the absence of secure rights to property plays in the evolution of Russia and the failure to understand that without it and its historical derivations either a modern state with a genuine market economy or a state governed by law is inconceivable have vitiated much Western analysis of Russia that insists on comparing it to states which have precisely this missing ingredient (Blank, 2008, p.234).

Indeed, the right to own property is one of the critical rights of a citizen. In Russia, this right has been absent so far. The tsars used to take away property from disobedient aristocrats. Putin has done the same, for example, Yukos. Law is certainly an important element of the transition from pre-modernity to modernity, as long as it protects individuals from the arbitrary rule of a power holder. For law to play this role in continental Europe is a question of the balance between rights and goods.

While analyzing the Rechtsstaat, Weber became strongly critical of the Sozialstaat.

Weber's SL [Sociology of Law] is first and foremost an intense confrontation with what was a transformation of state and society in Weber's own time: specifically, the transition from the nineteenth-century liberal state, or Rechtsstaat, to the administrative/welfare state, or Sozialstaat, of the twentieth century. (McCormick, 2007, p.2).

At the time, the Sozialstaat was a product of the complex set of the multitude of regulations related to the distribution of public goods. As such, the Sozialstaat became indeed the vehicle for the movement away from the Kantian negative freedom towards 
von Mohl's positive freedom. Of course later, when the Rechtsstaat and Rechtsstaatlichkeit will be moving the German state back to Kant's vision of it, the Sozialstaat will move as well by being incorporated into the 1949 Grundgesetz. Until then, and certainly at the time when Weber was analyzing it, he had a good reason to associate the Sozialstaat with pre-modern paternalism. Going backward, however, is irrational, especially if law is used for this. After all, for him, modern western societies shared a legal order characterized by rationality (Kronman, 1983, p.73).

Thus, for Weber the Sozialstaat was a degeneration of the Rechtsstaat. The latter went the wrong way. Instead of fostering freedom and rights, it was strongly deemphasising both. And while doing so, it used law to institutionalize the personalized rule of the chancellor by making the personalization impersonal or, perhaps, non-personal. In other words, the recreated modern feudal ruler was not the person who held the office of chancellor, but rather it was the chancellery itself, for it commanded both rights and goods to be dispersed through law but at the discretion of the office holder.

By losing its original Kantian origin and therefore the idea to use reason to rationalize political rule, the Rechtsstaat was simply turning into a mere regulatory machine.

In 1928, Hans Kelsen in his "Pure Theory of Law" ("Reine Rechtslehre") radically affirmed the identity of the state and the law. The state was nothing but Rechtsstaat in a formal sense of the term (Koetter, 2013).

The machine had no substance other than just producing regulations. In turn, regulations were just rules to follow by robots-like people. Reason was replaced by legalistic procedural mechanisms. The Sozialstaat was firming up the faceless, paternalistic rule. Rights are normative, they need rationalization and they require citizens. A regulation on how to obtain, say, insurance payments, is just that - regulation.

Putin has been determined to set up the Pravovoe Gosudarstvo in that degenerated form. In fact, the Pravovoe Gosudarstvo was all along degenerated. However, to re-launch government in Russia, Putin had no choice. When he came to power, the Russian Federation was on the way to collapsing. The decade of Yeltsin's presidency with its "wild, wild capitalism" was about to destroy whatever remnants of governance were carried over from the Soviet state.

That is where Putin came in. He was and is personally committed to reaffirming central state power vis-a-vis the "oligarchs," the mass media, and the republics and regions. And what is scarcely less important than Putin's determination to re-establish central state power is the fact that there are many in the federal administration-whether presidential or governmental-who have been waiting impatiently for such leadership. That a handful of rich businessmen should have exerted so much influence over public policy and the mass media is anathema to them, as is the idea that any republics or regions should be beyond central control. Putin, in other words, has an institutional base for reinventing the strong state. (Brown, 2001, p.47, italics original) 
Given the popular support for Putin coming from the Russians, they, too, were waiting for the strong leader and the strong government, for as Putin noticed, “... from the very beginning, Russia was created as a supercentralized state. That's practically laid down in its genetic code, its traditions, and the mentality of its people" (quoted in Brown, 2001, p.51). Moreover, "[t]here [was] strong demand from within the federal center for a restoration of lost power. If Putin [could not] supply it, some of his current supporter [might] look for someone else who [would]" (Brown, 2001, p.51).

In the past, and not too distant, the ruler could simply apply terror, kill the opponents, real or imagined, and retain all the strings of power in his hands. Those times are gone now, especially after the Yeltsin decade. During the 1990s, Russia stopped being insulated from the outside world the way the Soviet Union was. This does not mean, however, that Russia has embarked on the road to liberal democracy. Instead, as it seems, the Russian Federation when it emerged from the USSR was more or less at the point Germany had been at the time of the unification: personal rule was longed for; the state was weak; governance was problematic; modernity was encroaching; no true reformers were present; and the legitimacy of the power holder was questionable.

Under the circumstance, when Putin came to power, his work was cut out for him. The Russian flirtation with western ideas and democracy in the 1990s became a miserable experience, similar to the Germans' experience with the Weimar Republic. Thus going west was not an option; going straight back to the past was not an option either. Putin can be a lot of things to a lot of people, but Ivan the Terrible or Stalin he is not. The only viable choice was that supercentralized state; supercentralization, however, needed to be overhauled by being updated to accommodate the changes that occurred after the end of the USSR.

Even though Russia had the pravovoe gosudarstvo as an idea since the nineteenth century, it was never really practiced. Instead, it was more of an ideal formed as a concoction of some western thoughts and practices mixed into Russia's realties and tradition. However, now was the time to put the idea and ideal into practice. As Putin explained it,

A very important part of our common work is to strengthen the vertical structure of power. This presupposes control by the federal centre and effective feedback. I am confident that the State Council can be an excellent tool for such interaction (quoted in Brown, 2001, pp.50-51).

The Council is formally an advisory body to the president composed of regional leaders. When Yeltsin left office, the regional governors ran the federal units as if they were their personal fiefdoms. By gathering them in one place and under his control, Putin has neutralized their influence in the regions. This way the Council, which he controls, has greatly increased his power. And since the Council is institutionalized, regulation is the chief method of keeping tabs on the governors. Thus, by using law, Putin actually increased his power, which in Russia is not the usual way of doing it. 
Archie Brown points out Putin's selective use of law as a way of strengthening his power (Brown, 2001, p.48). Blank highlights the role of law in the work of the FSB, as envisioned by Putin: "This [security] work must be done strictly in line with the law and all of your steps must be based on the Constitution and Russian laws" (Blank, 2008, p.247). This sounds like a "KGB by the book." The security service, as the ruler's direct instrument of power, can still be used whenever and wherever he deems it necessary. But this time, his control over the service and the service's control over all others is to be done through law. The same is applicable to the tax-collecting service, for example.

The Federal Tax Service has also proposed expanding the range of sources that can or must submit information on the population's incomes to the tax authorities. This would include organizations that pay cash prizes to individuals, information on all sales of movable property, and the sales of means of transport (Blank, 2008, p.248).

If the proposition is to make sense, the collection of the tax information and taxes requires a structure and regulation. Given the nature of the information to be collected, the regulation has to be precise and detailed. Consequently, the legalism of the Rechtsstaat is replicated in the Putin version of the Pravovoe Gosudarstvo. Law, that is, regulation, reflects the changed supercentralization scheme instigated by the fleeting arrival of the west in Russia in the 1990s. Blank quotes a Russian analyst's take on Putin's use of regulation:

To retain his influence in the country, according to available data, he is putting the real prerequisites into operation: In the first place, he is de-facto putting the power structures under his jurisdiction, in the second place, the government and the Duma will be in his hands, in the third place, control over the mass information media will be switched to the government machinery, and in the fourth place, the role of the president's staff will be reduced (as in the United States) to the technical servicing of the work of the new president (quoted in Blank, 2008, p.250).

This looks like the regulatory machinery of the Rechtsstaat.

He also refers to the idea of "regular government" that some tsarist reforms in the eighteenth and nineteenth centuries tried to put in place in order to improve governance. (Blank, 2008, p.250). If this idea indeed guides Putin, it cannot be a mere replication of it.

The "regular government" was about centralized, flawless operation and, thus, perfect organization. In reality, the tsarist government was anything but flawless and perfect. It relied on force, ad hoc actions and improvisation. The tsars did not depend on law, even if they wanted to, precisely because of the malady of their rule, which certainly was the case in the nineteenth century. The tsarist bureaucracy was indolent, corrupt and fragmented. Therefore, to set it up successfully, the "regular government," needs to be significantly "irregular." What will stay regular is the status of the people, who are to remain subjects, and freedom and rights will continue to be in 
the domain of the state. The irregular is to be the amplified efficiency of governance achieved through the use of law in the form of the Pravovoe Gosudarstvo readjusted through the inclusion of the Rechtsstaat.

Mr. Putin would take up this mission in earnest as president. Within months of taking over the presidency in January 2000, Mr. Putin worked to rebuild state power by constructing a "rule-bylaw state" where law formulated by the presidential administration would be implemented in the country by courts and prosecutors. This Putinist legal system relied heavily on the "strategicoperational dichotomy" that Mr. Putin had outlined in his plagiarized thesis. The president formulated strategic policy through lawmaking, and judges and prosecutors monitored the implementation of these laws though the judicial process. To implement this legal power vertically, Mr. Putin focused his attention on coordinating legislative policy with parliament by simplifying legal codes and signaling to judges and prosecutors that he would expand their power in return for loyalty (Partlett, 2012).

His rule-by-law state is to have an orderly structure for using law as a critically important and positively efficient tool of modern governance utilized for an updated, that is institutionalized personalized rule of Russia's leader.

Using law to improve governance was also Gorbachev's idea.

[d] uring the last years of its life the Soviet Union turned to law like a dying monarch to his withered God ....and the Congress and Supreme Soviet enact[ed] and amend[ed] statutes with the fervour of one who sees in legislation the path to paradise (Rudden, 1994, p.56).

Gorbachev desperately tried to save his power and the Soviet Union. Legislation was one of the ways to do so. However, he did not have a workable plan for reform and a way of executing it. Even worse, Perestroika and Glasnost carried the tint of westernization, which meant that they were to be planted into a milieu that was not fertile. This rendered them artificial. Moreover, he did not control the state apparatus. The bureaucrats by and large were in opposition to him. As a result, it could be bills or beats, for his reforms were Hail Marys thrown into the wind of disintegration and chaos. This is not the case with Putin.

No doubt, Putin's plan to strengthen Russia is systematic. It includes a vision of what a reformed Russia is to be like. It is to be efficient, governable, wealthy and influential. Also, it is to be regulation-based. But it is not to be western. Instead, it is to have some western elements squared with the Russian tradition.. It is to be a sovereign democracy, “... a concept linking selected western democratic attributes with a nativist Russia-centric vision” (Ruth, 2012, p.230; see also, Remington, 2007; Monaghan, 2008; Stent, 2008), which is often promoted as “... a kind of new national ideology” (Averre, 2007, p.174) or managed democracy “... [which] will have all the formal institutions of democracy: elections, parties, media, civil society, and so on. But the real autonomy of these institutions and, therefore, their real capacity to influence the actions of the state will be severely limited." (Lipman and McFaul, 2001, p.116). The former is personalized rule by regulation, the latter is supposed to be Russia's 
contribution to the different forms of democracy, quite likely a Russian version of German democracy.

Because of his KGB years, Putin is intimately familiar with Germany, the language and the ways the state and society work. If regulation works in Germany, it can work in Russia. If Germany is a democracy framed by the wide-ranging and all-embracing legislative system, Russia, too, can be democratic with its own equally comprehensive regulation. Since Germany is rich, Russia can be rich as well. Germany is not a carbon copy of the Anglo-Saxon rule of law. Russia can also have its own version of it. Germany works well. Russia will work well, by the same token.

For Putin, there can only be one conclusion here: the Rechtsstaat is to be incorporated into the Pravovoe Gosudarstvo; but the incorporation must be on Russia's terms. When this is accomplished, Russia will have the old ideal of the "regular government" in reality. The tsars did not do it. The general secretaries did not it. Putin, at least according to Putin, can do it. If so, he will be the saviour of Russia now and later. When he is gone, the Russian version of the rule of law will stay in place. There were Catherine the Great and Peter the Great, both imported western elements to Russia and this worked, but only for a while. Well, neither of them included law into their importations and used it to make their reforms successful. Now is Putin's turn. Since he is employing the Russian version of the rule of law, the reforms will last, just like in Germany. Or will they?

The Rechtsstaat was from the beginning accompanied the Sozialstaat, which was constantly growing. In 1911 the Reich insurance system was extended to civil servants and, generally, white-collar workers. The unemployment insurance was introduced in 1927. More and more public goods were distributed to more and more segments of society. And as long as the Sozialstaat worked well, the Rechtsstaat could continue the trade-off: goods but not freedom and rights. When the state could not deliver the goods during the Weimar Republic, the governance was immediately weakened.

What about the Russian Sozialstaat? Where are the goods? They have never been aplenty in Russia. The USSR had problems with their quantity, quality and delivery; but then, the Soviet people did not pay taxes. Now, the Russians do. To be able to deliver the goods and maintain the original trade-off of the Rechtsstaat, Putin has to have the means, that is, functioning economy. Since Yeltsin linked it to the global economy, Russia's economy has become driven by the markets. Of course, it can still be regulated, but it cannot be controlled the way the tsars or general secretaries could and did, or Bismarck.

When Bismarck was setting the Rechtsstaat, his government, like most other governments at the time, was involved in the economy in a direct way. That was then, however; now, in a globalizing world, state intervention has been substantially reduced, for the role of the state has profoundly changed in recent decades (Lake, 2010; Goodhart and Taninchev, 2011). And so has the utility, quantity and quality of state regulation. Even worse, market economy needs independent courts that can adjudicate contractual disputes, for example, without the unduly political 
interference. Putin, however, wants loyal judges, not independent ones. Independent courts would require sharing of power. However, sharing of power has been so far incompatible with Russia's rulers.

The absence of a functioning Sozialstaat in Putin's Russia is certainly a problem if his Pravovoe Gosudarstvo is to succeed. But can he solve the problem if he puts in place the Sozialstaat, efficient as it could possibly be, no matter how difficult this task would be? Jürgen Habermas summarized Weber's critical view of the Bismarckian Sozialstaat in the following way:

Paradigms harden into ideologies insofar as they systematically close themselves off from the perception of radically new situations and resist different interpretations of rights and principles, interpretations that press for acknowledgment in the light of radically new historical experiences [,] ... [which] stabilize themselves through professionally and judicially institutionalized monopolies on interpretation and permit only internal revision according to their own standards (Habermas, 1996, p.221).

Because the Sozialstaat that Weber dealt with lost rational-formal law, it could not adopt itself to radically new situations, that is, societal change.

By the time Habermas analyzed the Sozialstaat, it had regained its rationality, which is why it now strengthens constitutional democracy. It is so, for

... [1]aw is ... both institutionally administrative and socially participatory because it translates popular will into government action. It is generated by public communication but also reaches back into society to foster the conditions of further communication. (McCormick, 2007, p.216)

Whether Weber or Habermas, Putin's Pravovoe Gosudarstvo appears to be doomed.

If it is Weber, degeneration of any kind by definition cannot succeed. The Rechtsstaat without Rechtsstaatlichkeit is out of date and out of purpose, therefore. A creation from the nineteenth century cannot work in the twenty first century. The kind of society that existed then does not exist today.

If it is Habermas, then Putin is playing with fire. The non-degenerated form of the Sozialstaat will create solidarity leading to the formation of community whose members will demand rights, for they will act rationally. To put it crudely: instead of choosing to be fed rather than have rights, the Russians will sooner or later choose both.

Law is an important factor of societal change, but only if it is in the form of rule of law. And if it is, the state becomes the representation of the political will of the people. This is not the case with the Pravovoe Gosudarstvo, for it instills collectivism by regulation. The state is the representation of the will of the power holder. And rights can only by afforded by the state. Law is also essential for community formation: to live together, we need rules. To live by them, the rules ought to be a result of a deliberative process, for law is a practice, “... an assemblage of rules, principles, canons, maxims, customs, usages, and manners that condition and sustain the activity of governing” 
(Loughlin, 2003, p.30). As such, law is public because it is formed on the basis of public will; it changes along with society, for it is the sum of its will. In the Pravovoe Gosudarstvo community is not formed; it is imposed. Law is private, for it is formed by the power holder. It changes when the power holder decides to change it, for it is the sum of his will.

The Rechtsstaat has been a prominent part of the development of law, legal systems, practice, and culture in Europe. It has significantly contributed to the development of codified law. At first, it facilitated the introduction of regulation as a step in the process of moving away from feudalism. Later, with the Rechtsstaatlichkeit, it became a way of incorporating the rule of law, thus turning into a path to liberal democracy. As a result, the Rechtsstaat has markedly modified the substance of the legal and the utility of the practical. The legal has changed from what the ruler has passed to what the state as the representative of the popular will has legislated. The practical has moved from serving the ruler to becoming the practical expression of representation through which “... conflict [can] be positively harnessed, appropriate governing arrangements devised, and real political will established” (Loughlin, 2003, p.64).

Walter Bagehot, while commenting on the British Reform Acts of 1832 and 1867, observed:

A new Constitution does not produce its full effect as long as all its subjects were reared under an old Constitution, as long as its statesmen were trained by that old Constitution. It is not really tested till it comes to be worked by statesmen and among a people neither of whom are guided by a different experience (Bagehot, 1873).

Given the central position of Germany in Europe, the country's political influence and intellectual prominence, the Rechtsstaat played a prominent role in the rearing of both the rulers and the ruled. At first, it transformed personal, direct rule of the feudal landlords into institutionalized, personal rule of post-feudal rulers, and converted peasants into subjects. With the addition of Rechtsstaatlichkeit, the rulers have become elected officials and the subjects have become citizens. In the end, by now almost all of Europe's states and societies moved from "We the Ruler" to "We the People”.

\section{Bibliography}

Averre, D. (2007). ‘Sovereign Democracy’ and Russia’s Relations with the European Union. Demokratizatsiya, 15: 173-90.

Bagehot, W. (1873). The English Constitution. http://socserv2.socsci.mcmaster.ca/econ/ugcm/31l3/ bagehot/constitution.pdf.

Barry, D. (Ed.) (1992). Toward the 'Rule of Law' in Russia? Political and Legal Reform in the Transitional Period. New York: M. E. Sharpe.

Beveridge, W. H. (1944). Full employment in a free society: a report. London: G. Allen \& Unwin.

Blair, P. (1978). Law and Politics in Germany. Political Studies, 26: 348-62. 
Blank, S. 2008. The Putin Succession and Its Implications for Russian Politics. Post-Soviet Affairs, 24: 231-62.

Bossuyt, M. J., Alen, A., Joosten, V., Leysen R. and Verrijdt. W. (2013). Liberae Cogitationes: liber amicorum Marc Bossuyt. Cambridge: Intersentia.

Brown, A. (2001). Vladimir Putin and the reaffirmation of central state power. Post-Soviet Affairs, 17: 45-55.

Goodhart, M., and Taninchev, S. B. (2011). The New Sovereigntist Challenge for Global Governance: Democracy without Sovereignty. International Studies Quarterly, 55: 1047-68.

Habermas, J. (1996). Between facts and norms: contributions to a discourse theory of law and democracy Cambridge, Mass.: MIT Press.

Heater, D. B. (2004). A brief history of citizenship. New York: New York University Press.

Hendley, K. (1996). Law and Development in Russia: A Misguided Enterprise? Proceedings of the Annual Meeting (American Society of International Law), 90: 237-40.

Jackson, G. D., and Devlin, R. J. (1989). Dictionary of the Russian Revolution. New York: Greenwood Press.

James, H. (2000). A German identity: 1770 to the present day. London: Phoenix Press.

Knox, R. A. (1993). Germany - one nation with health care for all. Washington D.C.: Faulkner \& Gray's Healthcare Information Center.

Koetter, M. (2013). Rechtsstaat and Rechtsstaatlichkeit in Germany. Freie Universitaet Berlin, Accessed March 14, 2016. http://wikis.fu-berlin.de/display/SBprojectrol/Germany.

Kronman, A. T. (1983). Max Weber. London: Edward Arnold.

Krueger, A. B. (2000). From Bismarck to Maastricht: The march to European Union and the labor compact. Labour Economics, 7: 117-34.

Lake, D. A. (2010). 'Rightful Rules: Authority, Order, and the Foundations of Global Governance. International Studies Quarterly, 54: 587-613.

Lipman, M., and McFaul. M. (2001). Managed democracy in Russia - Putin and the press. Harvard International Journal of Press-Politics, 6: 116-27.

Loughlin, M. (2003). The idea of public law. Oxford-New York: Oxford University Press.

McCormick, J. P. (2007). Weber, Habermas, and transformations of the European state: constitutional, social, and supranational democracy. Cambridge: Cambridge University Press.

Monaghan, A. (2008). ‘An Enemy at the Gates’ or ‘From Victory to Victory’? Russian Foreign Policy. International Affairs (Royal Institute of International Affairs 1944-), 84: 717-33.

Partlett, W. (2012). Mr. Putin’s ‘Rule-by-Law State’, Accessed March 15, 2016. http://www.brookings. edu/research/opinions/2012/06/19-putin-law-partlett.

Qamar, N. (2013). Hak asasi manusia dalam negara hukum demokrasi (Human Rights in Democratiche Rechtsstaat). Jakarta: Sinar Grafika.

Radich, N. A. (2016). 'A single health care system for a reunified Germany. Accessed March 12, 2016. http://martindale.cc.lehigh.edu/sites/martindale.cc.lehigh.edu/files/radich.pdf.

Remington, T. F. (2007). On the RPSA's Fourth Congress. PS: Political Science and Politics, 40 : 187-87.

Rudden, B. (1994). Civil Law, Civil Society and the Russian Constitution. Law Quarterly Review, 110.

Ruth, M. (2012). Introduction: Transition to Where? Developing Post-Soviet Space. Slavic Review, 71: 223-33.

Sakwa, R. (1996). The Struggle for the Constitution in Russia and the Triumph of Ethical Individualism. Studies in East European Thought, 48: 115-57.

Silkenat, J. R., Hickey, Jr., J. E., Barenboim P. D., and Link, S. (2014). The Legal Doctrines of the Rule of Law and the Legal State (Rechtsstaat). In lus Gentium: Comparative Perspectives on Law and Justice, XII. Springer International Publishing.

Stent, A. E. (2008). Restoration and revolution in Putin's foreign policy. Europe-Asia Studies, 60: 1089-106. 
Strauss, L. and Cropsey. J. (1987). History of political philosophy. Chicago: University of Chicago Press.

Vincent, N. (2012). Magna Carta: a very short introduction. Oxford: Oxford University Press. Walicki, A. (1987). Legal philosophies of Russian liberalism. Oxford: Clarendon Press.

Weber, M. (1947). The theory of social and economic organization. Oxford-New York: Oxford University Press.

Weber, M. (2003). The Protestant ethic and the spirit of capitalism. Mineola, N.Y.: Dover Publications. 


\section{Dorota Pietrzyk-Reeves ${ }^{1}$ \\ 5 Magna Carta and the Rise of Anglo-American Constitutionalism}

\subsection{The Great Charter}

The history of institutions is inseparable from the history of ideas, but sometimes it is the institutions that inspire the development of political ideas. In case of Magna Carta that became part of the English constitution it certainly was the latter. A practical solution to political problems caused by the rebel barons gathered in London in 1215, Magna Carta established principles fundamental for the institution of the rule of law which later on British and American political thought has spread throughout the modern world (Madden, 2005, p.10). My main research question in this essay is to what extent an interesting parallel between Magna Carta and its legacy and later constitutional developments that took place in Europe and America can be determined. This parallel, or perhaps even inspiration, would indicate that there is a common heritage to the ideas of constitutionalism in Western political thought and legal culture. In order to do that I look at the ideas that shaped Magna Carta and their transmission into later periods and contexts. One of these contexts that is examined here is the rise of constitutionalism in the Polish Commonwealth in the early sixteenth century.

The English barons upon whose demand king John decided to grant the first charter of liberties that we know, the famous Magna Carta Libertatum, insisted simply that the king obeys his own rules. The dispute was to be set not by war, but trough a legal process. Sixty three clauses included in the document had local and universal meaning, it was a hotchpotch of various interests, but it also had appeal to justice. The most fundamental of these was the idea that the king must be bound by the law of his kingdom, that the law which comes from the ruler is observed by him so that he does not act in a tyrannical way. But it was not the king who willingly singed the Carta, it was the position of the barons who made him do so and thus brought to an end the state of civil war. There is a strong similarity between the English barons at Runnymede meadow demanding their liberties and the Polish noblemen in the fourteenth and fifteenth centuries declaring that they would not fight a war or agree to changes in dynastic succession if the king did not grant them certain rights (called privileges). The aim of this article is to bring to light this and other parallels in medieval and early-modern European history so that Magna Carta can be seen as one of the most important documents of early constitutionalism. Its significance lies in both legal and

1 The Jagiellonian University in Kraków. 
symbolic meaning, in the message that it conveyed upon others both in England and elsewhere as to what were the limits of monarchical power and who decided about these limits. Although the Great Charter 'did not save England from Tudor despotism', as one author observed, it "was despotism of fact rather than of law." As a charter of liberties Magna Carta did not mentioned any sanctions in case the king infringed upon the rights it mentioned, and that certainly was one of its weaknesses, but at the same time it was a clear assertion of fundamental rights of various groups within society, however differently they have been listed at different periods. It will be argued that Magna Carta is unique in comparison with other similar documents issued in medieval Europe because of the uniqueness of the English unwritten constitution as well as legal and political culture that it helped establish throughout the centuries. But those other instances of constitutional developments, including above all the Polish development help situate Magna Carta and political and legal ideas it instigated in a broader context of medieval Europe and early-modern republicanism.

Chapter 39 of Magna Carta states the credo of modern constitution in Europe and later on in America: "No free man shall be arrested or imprisoned, or disseised or outlawed or exiled or in any way victimized neither will we attack him or send anyone to attack him, except by the lawful judgment of his peers or by the law of the land" (Rothwell, 1975, p.312). In the fourteenth century the same right was granted to Polish nobility (the difference was that instead of a 'free man' the act referred to 'a noble man', the category somehow more limited although it was soon to include around ten percent of the Polish society). The Coronation Charter issued by Henry I on 5 August 1100 precedes Magna Carta as an example of a promises made by the new king to various sections of his feudal community including the church (Turner, 2003). This medieval custom of the new king biding for support and making a pledge with his people was to become common in Poland, especially with the rise of the Jagiellonian dynasty which itself was established as the result of an agreement between nobility and the king. It was precisely that first basic text of Henry I which the rebellion of 1215 demanded that it should be confirmed and reissued. And both documents start with the liberties of the church and then proceed to feudal incidents.

In his statute of 1225 reissuing Magna Carta, Henry III states again that the liberties in question were "to be held in our kingdom of England forever." It was a royal act of will: spontanea et bona volunta nostra. In a similar manner the liberties of Magna Carta as well as the Charter of the Forest were approved and renewed by Edward I in 1297. The concession of the king was a transaction made and remade for the benefit of all parties concerned, by men "used to receiving grants of liberties" (Holt, 1993, p.47). Granted in perpetuum the charters were unusual as they were going beyond the original concession and reflected the emergence of the communitas regni, a political phenomenon and a concept of men who were now in possession of liberties that could not be simply dismissed or invalidated. In this sense Magna Carta was a constitutional act, the origin of future legislation (e.g. the Provision of Merton of 1236) and thus the first statute. But it still remained a privilege. It was the same manner of 
issuing at the same time a statute binding upon the kings in perpetuity and a privilege granted with a certain sections of the society in mind that prevailed in Poland from the fourteenth century onwards.

Magna Carta became real and not only symbolic as a constant point of reference for those discontented subjects of their monarch, first in England and then in American colonies, who simply demanded the reconfirmation of the document as the starting point for political reform and guarantee of justice, or as a safeguard against tyrannical rule. Shortly after king Jonh's death in 1216 the Great Charter was quickly reissued in 1217 and its definitive version came in 1225 . When thirty years later the barons of king Henry III demanded again that the king would keep and observe the charter of liberties of England, this validation of the charter was a significant act, an example of the personal oath of the king that he would abide by the terms agreed earlier by those present at Runnymede. Henry Bracton, the English jurist whose legal theory must have been influenced by the Great Charter, declared that 'The law makes the King', and not the other way round, adding that 'there is no king where will rules and not law' (White, 1908, p.268). The fundamental legal principle now was that the king must not take the definition of rights into his own hands, but must proceed against none by force for any alleged violation of them until a case has been made out against such a one by "due process of law” (McIlwain, 1975, p.78).

An important question that needs to be addressed is whether the king was legally bound to reissue Magna Carta or was it purely his will to do so? The king and the nobility with him took a solemn oath to observe omnes libertates praescriptas. In other words, it came as the result of their will and thus the king had only a moral obligation to stand by his oath. Henry III reissued Magna Carta simply by his own free will (spontanea et bona voluntas nostra) and not as a binding constitutional law by some other source (Mcllwain, 1975, p.73). Such interpretation comes from Henry Bracton (Maitland, 1887) stating that prince's will is law in accordance with lex regia that stipulates what the law already is, promulgated by the king after a discussion with his magnates who demand observance of an ancient custom. A long tradition of treating the charter as valid was to make it a clear part of what was later called "the ancient constitution" of England. According to Bracton, binding law was the result of king's will being in conformity with lex regia, the laws the people have chosen. For American founders it came almost naturally to include Magna Carta in their own constitutional provisions as an ancient custom the subjects of the English king could call upon.

In England Magna Carta was seen as sacrosanct still in the fourteenth century and statutes that conflicted with it were ruled invalid, which as a norm was confirmed by a statute enacted by Edward III in 1369 who further developed what was to be called 'a due process of law' (Turner, 2003). However, by the mid fifteenth century Magna Carta was overshadowed by high politics and the strong reassertion of royal sovereignty by the Yorkist and Tudor monarchs. But even then Magna Carta remained the first of statutes of the English constitution, protector of landed property. Ignored by Henry VIII, in the seventeenth century Magna Carta and the doctrine of ancient 
constitution that was emerging played the key role in the conflict between king and Parliament. The notion of 'the ancient constitution' was used by members of Parliament who searched for a body of laws and customs that imposed limits on the royal power over the subjects. But it was Sir Edward Coke who took the English constitution as "a chain of royal confirmations of English law, stretching back to the age of Edward the Confessor and and beyond" (Turner, 2003) and insisted that "the king by his proclamation or other ways cannot change any part of the common law, or statue law, or the customs of the realm" (Wilson, 1777, p.75).

\subsection{Magna Carta as a Model in Medieval and Early-Modern Europe}

In Central Europe a similar development took place in Hungary and later on in Poland. The Golden Bull of Hungary (Aranybulla) of 1222 issued by King Andrew II who, like King John I in England, was forced by his nobles to accept an act that placed constitutional limits on the power of the monarch. The edict established the basic rights and privileges of Hungarian nobility and clergymen. Caused by Andrew's excesses and extravagances, the act contains 31 articles reaffirming previously granted rights and bestowing new ones: "Since the liberties established by St. Stephan the king in favor of the nobles of our realm was well as of other persons have been diminished in many respects by the authority of certain kings. [...] We therefore desire to fulfill their requests in all respects as we are obliged to do [...] for the better preservation of the royal dignity which can be done better by no one other than by them. We grant both to them and to other men of our kingdom the liberty given by the holy king” (Bak, 1999, p.34). There is no textual link between the document and Magna Carta although we may speculate that their affinity is so striking that there must have been some inspiration coming from the English charter (Rady, 2014).

In 1241 Danish king Valdemar the Victorius issued the Jutland Code which established the concept of the legal order as a contract between ruler and people. It was strengthened by the charter of 1282 signed upon the demand of nobility by king Erik V. Both documents are regarded as forerunners of the subsequent Danish constitutional law. The Jutland Code, the oldest civil code in Denmark, was first drafted by a royal committee and passed by the Lndsthing at Viborg before being finally issued by the king. In 1326 it was ratified as official law and made applicable to all parts of Denmark (Orfield, 1954). According to the Code, legislation was to be based on universal justice to be legitimate. In other words, the source of law was to be found in natural law and not in the will of the ruler. In stating that 'No man may meddle with the law, and the king may not set it aside without the will of the land', it followed Magna Carta as a single document valid in the entire kingdom that aimed at making the law a binding power upon the ruler and the ruled. Like Magna Carta, the Code provided a regular and fixed form to the ancient customary law without constituting anything unknown before. The result of struggle between the king and nobility, the 
Charter of 1282 secured a number of rights to nobility including the king's promise not to convict anyone without legal basis and not to rule in an arbitrary manner. The Code and the Charter were adopted by assemblies comprised of king, bishops and the nobility constituting together a representative body whose union was needed to make the new law valid. The Preamble of the Jutland Code stated that "A land must be built on law [...]" which must be "honest and just, reasonable and according to the ways of the people. It must meet their needs and speak plainly so that all men may know and understand what the law is. The law is not to be made in any man's favour, but for the needs of all who live in the land" (The Jutland Code 2008, p.21).

The Privileges of the Union of Aragon granted by the king in 1287 is another instance of a statute for which the Magna Carta could serve as a model. "The King vows and binds himself, his heirs and successors and any person acting on his or their part not to arrest, detain, expropriate or hold the property of any of the nobility or others of the Kingdoms of the Crown of Aragon." Consequently, the idea behind the Privileges was that of the sovereignty of law, of making resistance to the crown legal though extraordinary (Madden, 2005, p.167). From the earliest times in Spanish political thought justice was not only the end of human society, the norm regulating political community and the only justification of the state or rather the political rule was its duty to secure justice (Madden, 2005, p.14). The document was unique in the Middle Ages as it contained a clause allowing that the reigning king may be abandoned and another elected if he contravenes the articles of the Privileges (Gissey, 1968, p.88).

In the 1355 Treaty of Buda and the Košice privilege of 1374, Louis of Anjou, king of Poland and Hungary promised certain analogous rights to Polish nobility to ensure Angevin dynastic claim, the unprecedented succession of a female to the Polish throne. The charter of 1374 exempted the nobility from any payment of taxes to the crown, except a minor duty on their lands, without their explicit approval. It also assured the nobility that the most important royal appointments would go only to Poles and that offices in regional administration in each province would go to candidates nominated by the local nobility. The charter also stated that the nobility would be required by law to fight without pay within the borders of the kingdom, but any military service outside its borders was to be remunerated at a specific rate (Fedorowicz, 1982). At Košice Louis I also renewed a pledge made during his coronation to maintain the Polish kingdom's territorial integrity.

Similarly, the privileges issued at Jedlnia (1430) and Krakow (1433) by King Władysław Jagiełło in order to secure the succession of his progeny to the Polish throne, granted to the whole nobility one of the most important civil liberties: Neminem capivabiums nisi iure victum ('We shall not imprison anybody unless they have been convicted by law'), as the first words of the document stated. Although it is underestimated and forgotten in the history of European legal culture, the Neminem Captivabimus granted the rights that were comparable to those granted not only by Magna Charta but also by the later Habeas Corpus Act of 1679. In 1454 the nobility were granted the right to participate in the legislative process by which new law 
proposed by the king could not be valid without the approval of the convention of the gentry called the landed diets. Finally, the constitution called Nihil Novi issued in 1505 demanded that the king had no right to legislate without the consent of both chambers of Polish parliament, the Senate and the Chamber of Deputies (Izba Poselska). From then on, it was impossible to introduce new laws or make changes related to the political system without consent of the nobility. The constitution, which was fundamental to the consolidation of nobility's political role, its representation as well as the mixed political system, proclaimed that:

'General laws and public acts do not apply to individuals but to the whole nation, thus, on this general Sejm in Radom, we, with all of the Kingdom's prelates, councils and representatives of sejmiks (local assemblies of nobles) deemed as fair and just that from now on nothing new (nihil novi) can be decided by us and our successors without the approval of senators and representatives of sejmiks. No ordinance that would bring dishonour on the Commonwealth, harm anyone or aim to change the common law and public freedom can be enacted' (Szymanek, 2005, p.123).

At the sejm in Radom, king Alexander Jagiellon promised also, at the representatives' request, to observe the laws (confirmatio iurium) (Volumina Constitutionum, 1996, pp.172-173). In practice, it meant accepting the superiority of law in the state and acknowledging it as a source of all authority. The Commonwealth's law was to originate from a widespread consensus and was to be directed at the common good, since it concerned res populi - the community and its well-being.

Like the Great Charter, the privileges limited royal power, and at the same time they transformed the relationship between the ruler and the nobles into a contractual relationship. Although formally the act of a monarch, in fact they made up a kind of social contract and contained the obligations of binding character supported with the clause on the possibility of renouncing the allegiance to the ruler (the right of resistance). This constitutional development contributed to the victory of the republican principles in Poland, which was best illustrated by the replacement of the term "Regnum", which so far was used to describe the Polish Kingdom, with "Respublica" (Rzeczpospolita), which highlighted the equality of its members/citizens. The goal of the nobility and republican political system, under the leadership of the king and parliament was to protect and maintain freedom from domination and self-government, which in practice frequently led to a conflict between freedom and the authority.

During that period a number of small charters of liberties (often called privileges as they were usually granted only to the nobility) and statutes shaped a constitution of a limited mixed government, the monarchia mixta of the Polish and later on Polish-Lithuanian Commonwealth. Similarly to England and Venice, Poland was called rzeczpospolita - res publica or commonwealth for its supreme norm was the welfare of the political community, bouns communi, and liberty of its citizens. The various acts of Polish monarchs granting rights and liberties to the citizens of Rzeczpospolita became a cornerstone of the doctrine of liberty cherished by republican writers and the whole class of noblemen. Subsequent concessions of the monarchs who often 
simply due to historical circumstances (e.g. external threat) were willing to limit royal prerogatives gave rise to a speedy development of a representative parliamentary system concentrated in the lower chamber of the Sejm and traditional land diets (sejmiki). This was further strengthened with the right of nobility (as a social class independently of the material status of each citizen) to elect the king.

The formula of the Charter of Liberties of 1215: "We have also granted to all the free men of our realm for ourselves and our heirs for ever, all the liberties written below" (Rothewell, 1975), which also applied to the Charter of the Forest, was not present in the Polish charters, but it was taken for granted that each subsequent monarch was obliged to keep all liberties intact. This was became a formal requirement imposed on elected monarchs in form of Articuli Henriciani first issued in 1572 which by and large were a written seal to all existing constitutional rules and liberties and of the kingdom and thus could be treated as the first constitution of the Kingdom (Lewandowska-Malec, 2009, pp.21-22). Additionally, all elected kings were supposed to enter a specific contract with the representatives of Rzeczpospolita called Pacta convent, a document that comprised of various obligations, promises and plans for reforms. Like Edward III in 1225, the Polish kings of the Jagiellonian dynasty, which itself was established as a contract between the king and nobility, and subsequent elected monarchs had to promise that nothing would be sought that would weaken or infringe the liberties. The transaction was to be constantly reinforced to ensure its permanence and certainty. And the very election of a king by consent of the subjects was seen as a sufficient guarantee of law and order of the commonwealth. Stanislaw Orzechowski, one of the most prominent republican authors in the sixteenth century stressed that a king is nothing more than the 'mouth of the kingdom' obliged by the free and lawful election to acting only in accordance with the will of his subjects and the law (Orzechowski, 1972, p.104).

The insistence of being granted in perpetuum in the case of both English Charters was unusual (2008, p.48). Another feature that both the Magna Cart and the Polish statutes and privileges shared was the fact that they were official documents with more and more detailed provisions. And as the final version of Magna Carta was to be used as vehicle for legislation, 'a source of law as well as a conveyance of liberties' (Holt, 2008, p.50), the same could be said of the statutes the Polish nobility so cherished. Similarly, these documents shared the unique feature of being both statute and privilege at the same time. Citizens could appeal to them against acts of government and the courts treated them as law that they would follow (Holt, 2008, p.51). The difference between these acts was quite striking. While Magna Carta was by 1422 confirmed in over fifty councils of parliaments, and had more general application as it referred to the category of "freemen", the privileges of Polish nobility were treated as the best weapon of free citizens against absolutum dominium and were limited to that were social class. And while Magna Carta was to be reinterpreted and adjusted to circumstances (as the very term 'freemen' was changing), the liberties of nobility were treated as fixed and unchangeable; they could only be extended. In the fifteenth 
and sixteenth centuries neither Polish nor English authors argued against monarchy. They were in favour of a mixed polity, monarchia mixta, or, to use the term which gained currency in today's scholarship, 'a monarchical republic' (Collinson, 1987). It was taken for granted in both Poland and England that only the ancient model of a mixed constitution could guarantee that the rule of law and liberty were preserved.

Charters of liberties and privileges contributed to the development of a mixed constitutional system of government in Poland that was first founded upon such concepts as corpus regni and in the sixteenth century replaced by new terms such as corpus reipublicae and respublica. New representative system now comprised of the king, treated not as a sovereign, but as an administrator of the kingdom (Zaborowski, 1507), and two chambers of parliament. Stanislaw Zaborowski stressed at the beginning of the sixteenth century that communitas regni was higher than the monarch advocating sovereignty of the people and arguing that the king was not the owner, but only an administrator of the kingdom. The 1505 Constitution Nihil Novi stated that nothing new could be decided without consent of nobility expressed by Izba Poselska - the lower chamber of parliament. It strengthened political liberties of citizens and successfully limited any attempts of the king to strive towards absolutism. The right to participate in state decision-making granted to all citizens became a crucial element of republican liberty and was additionally secured by civil liberties including religious freedom and freedom of speech. Although the concept of an 'ancient constitution' was not used in Poland, the statutes that guaranteed liberties also guaranteed the rule of law and limited government and were the main claim of the movement for the 'execution of the law' in mid-sixteenth century to limit various practices (e.g. granting royal estates to senators for loyalty and support) that infringed upon old customs and laws. The struggle of nobility against absolutum dominium on the one hand and the dominant position of aristocracy in government on the other hand not only gave the noblemen prominent position in political community for three centuries, but vastly influenced political consciousness supported by the republican theory that flourished in the sixteenth and the seventeenth centuries (Pietrzyk-Reeves, 2012). Additionally, the Act of Warsaw Confederation of 1573 guaranteed freedom of conscience and religious toleration to all estates of the Polish-Lithuanian Commonwealth.

The term 'golden liberty' which comprised of all the rights, liberties and privileges that the nobility could enjoy had a different practical meaning from the term 'ancient constitution', but its symbolic connotation was similar. It referred to fundamental norms of the commonwealth whose sacred statutes could only be preserved as long as its practical validity was intact. At the same time the development of nobility's privileges and consequently the growth of rights of the nobles had an enormous impact on the constitutional system of the Polish Commonwealth since it generated the mechanisms and legal guaranties of the nobility's privileged position in the representative system of mixed government (Uruszczak, 2008). The concept of cardinal or fundamental laws understood as the laws of superior and invariable character was fully established in the seventeenth century. These laws could be supplemented by 
new provisions but they were not subjected to review. They included Articuli Henriciani, pacta conventa, principles of free election of the monarch and all the privilegies, including particularly those that guaranteed the nobles individual liberties, as we would call them today, including protection of private property, freedom of conscience and religious freedom as we, as well as equal political rights.

Different historical circumstances led to different constitutional developments in Poland and England. The May Constitution of 1791, the second written constitution after the American constitution, was an attempt to establish a better institutional structure and to secure the rights of all three estates of the Commonwealth. In England some of the most important provisions of Magna Carta including habeas corpus were strengthened with numerous other acts including the Bill of Rights of 1689 and its lasting significance as both a symbol and fundamental law was reinforced so that its most fundamental provisions never lost its validity.

\subsection{Magna Carta in America}

Magna Carta is unique in comparison with other similar documents issued in medieval Europe because of the uniqueness of the English unwritten constitution as well as the legal and political culture that it helped establish throughout the centuries. But it was especially in America that Magna Carta became a symbol of a limited government in legal and political thought. It influenced American constitution even more greatly than European constitutionalism for it was taken by English colonists as the most cherished part of the legal tradition of their homeland that they still (until 1776) belonged to. The Massachusetts Body of Liberties of 1641 included a different list of liberties and provisions, being issued in different times and different circumstances, but the idea behind it seems to be similar to that of the Great Charter; to secure as many liberties to the colonists of Massachusetts as necessary at the time for the stability of churches and the commonwealth. Soon before the outbreak of the American Revolution in 1775, colonial lawyers and pamphleteers turned to Magna Carta for support against the British king. In October 1774 the first Continental Congress adopted a resolution which claimed that the colonists were doing 'as Englishmen their ancestors in like cases have usually done, for asserting and vindicating their rights and liberties' (Declaration 1774).

Later on it was the conviction of the Founding Fathers that England was founded on ancient constitution and that it was a government of law not of man. This idea of establishing the new fundamental law - a constitution for the colonies which were now an independent political community came from the long tradition of the common law and legal and political culture. John Adams insisted that "Where the public interest governs it is a government of laws, and not of men [...] If, in England, there has ever been any such thing as a government of laws, was it not magna charta?" (Adams, 1787, p.126). American colonists' attitude to politics and government, as Bailyn observed, 
"was fundamentally shaped by the root assumption that they, as Britishers, shared in a unique inheritance of liberty" (Bailyn, 1967, p.67). Among the first amendments to the new constitution ratified in 1791 to compose a Bill of Rights, number five most closely resembles 39th chapter of Magna Carta promising that no person shall be "deprived of life, liberty, or property without due process of law". The phrase "due process of law" would prove to be remarkably elastic in expanding the rights of American citizens. And amendment 6 follows provisions of chapter 39 promising accused persons the right to a "speedy and public trial, by an impartial jury," and the right "to be informed of the nature and cause of the accusation," the right "to be confronted with the witnesses against him", to call "witnesses in his favor," and to have "counsel for his defense." The colonists and the Founders of the American Republic treated Magna Carta as fundamental law, standing above both king and Parliament and unalterable by statute. Their commitment to such higher law strengthened their ambition for written constitution and the final federal constitution of 1787. And today the Great Charter has even higher symbolic meaning in the USA than in Britain supporting the concept of limited government in American legal and political thought. As Hazeltine in somewhat exaggerated words put it:

The history of the Charter's influence upon American constitutional development [...] should be illuminating alike to subjects of the Crown and citizens of the Republic. Above all it teaches them that English political and legal ideals lie at the basis of much that is best in American institutions. Those ideals, jealously preserved and guarded by Americans throughout their whole history, still form the vital force in political thought and activity within the Union (Hazeltine, 2012, pp.225-6).

Magna Carta was a symbol of liberty in early America and it remained so today. It is liberty understood as the absence of arbitrary power that could undermine the basic rights such as habeas corpus or free speech. The colonists' fundamental claim to ancient rights was the best weapon to protect themselves from the British rule when injustice occurred. Magna Carta thus provided both a symbol and a tool to strengthen the claims of the people in their relationship with political authority, to make this relationship more contractual and consequently to establish constitutional norms as fundamental, sacred and demanding respect of all.

\subsection{Conclusion}

Symbolic as it might be, Magna Carta, and especially its chapter 39, proved a lasting source of the doctrines which it launched on the mainstream of political thought and jurisprudence in Europe and America. By the seventeenth century such key concepts as trial by jury, the rule of law, limited monarchy, habeas corpus and Parliament's right to control taxation were traced back to the English charter. Parallel statutes or charters issued in other parts of medieval Europe never gained such prominence, but 
they also played a very significant role in shaping the doctrine and institution of constitutionalism that is of fundamental law of a political community. It was especially so in Poland where the roots of constitutionalism were indeed to be found in various charters of rights and privileges granted to the regnum and more precisely to its citizens who not only secured legal protection against absolutism (absolute dominium as they called it at the beginning of the sixteenth century) in the form of the rule of law and sovereignty of law, but above all established the foundations of a free political community - a monarchical republic whose citizens could enjoy liberty greater than that of most European societies at the time. During the period of A deep crisis of Rzeczpospolita in the eighteenth century it led to yet another development: the first written constitution later called the Constitution of 3 May adopted in 1791 which in different historical circumstance would perhaps have led to a similar stable constitutional order as that of the United States of America. The second and third partitions of Poland stopped that development. The story of Magna Carta is different for unlike other similar documents of medieval or early modern Europe it never fully lost its validity and binding force, it was never abandoned or outlawed in its entirety by some other act or event.

\section{Bibliography}

Adams, J. (1787). A Defence of the Constitutions of Government of the United States. London: John Stockdale.

Bailyn, B. (1967). The Ideological Origins of the American Revolution. Cambridge: Harvard University Press.

Bak, J. M. (Ed.) (1999). The Laws of Medieval Kingdom of Hungary, 1000-1301. New York: Charles Schlacks.

Collinson, P. (1987). The Monarchical Republic of Queen Elizabeth I. Bulletin of the Jon Rylands University Library of Manchester. Vol. 69, No. 2.

“Declaration and Resolves of the First Continental Congress" (1774 [1927]). In Documents Illustrative of the Formation of the Union of the American States. Selected, arranged and indexed by C. C. Tansill. Washington: Government Printing Office.

Fedorowicz, J. K. (Ed.) (1982). A Republic of Nobles: Studies in Polish History to 1864. Cambridge University Press. Cambridge.

Gissey, R. E. (1968). If Not, Not: The Oathe of the Aragonese and the Legendary Laws of Sobrarbe. Princeton: Princeton University Press.

Grodziski, S., Dwornicka, I., Uruszczak, W. (1996). Volumina Constitutionum 1493-1526. Warszawa: Wydawnictwo Sejmowe.

Holt, J. C. (2008). The Ancient Constitution in Medieval England. In E. Sandoz (Ed.), The Roots of Liberty: Magna Carta, Ancient Constitution, and the Anglo-American Tradition of Rule of Law. Indianapolis: Liberty Fund.

Lewandowska-Malec, I. (2009). Sejm Walny Koronny Rzeczpospolitej Obojga Narodów i Jego dorobek ustawodawczy (1578-1632). Kraków: Księgarnia Akademicka.

Madden, M. R. (2005). Political Theory and Law in Medieval Spain. New Jersey: The Lawbook Exchange Ltd., Clark.

Maitland, F. W. (Ed.) (1887). Bracton's Note book. A collection of cases decided in the King's courts during the reign of Henry the Third. London: C.J. Clay and sons. 
Mcllwain, Ch. (1975). Constitutionalism: Ancient and Modern. Indianapolis: Liberty Fund.

Orfield, L. (1953). The Growth of Scandinavian Law. Philadelphia: The University of Pennsylvania Press.

Orzechowski, S. (1972). Mowa do szlachty polskiej przeciw prawom i ustawom Królestwa Polskiego uporządkowanym przez Jakuba Przyłuskiego. In S. Orzechowski, Wybór pism. Wrocław: Zaklad Wydawniczy im Ossolinskich.

Pietrzyk-Reeves, D. (2012). Ład rzeczypospolitej. Polska myśl polityczna XVI wieku a klasyczna tradycja republikańska. Kraków: Księgarnia Akademicka.

Rady, M. (2014). Hungary and The Golden Bull of 1222. Bantica 24-II, pp. 87-108.

Rothwell, H. (Ed.) (1975). English Historical Documents 1189-1327. London: Eyre and Spottiswoode.

Szymanek, A. (Ed.) (2005). Konstytucja Nihil novi, in "Nihil novi." Z dorobku sejmu radomskiego 1505 roku. Radom: Stowarzyszenie "Anno Domini"

The Jutland Code and Erik Kippling's Charter, (2008). In The Danish Democracy Canon, The Committee established for the purpose of drawing up a democracy canon and the Danish Ministry of Education. Online: http://pub.uvm.dk/2008/democracycanon.

Turner, R. (2003). The Magna Carta throughout the Ages. London: Routledge.

Uruszczak, W. (2008). Species privilegium sunt due, umum generale, aliud special. Przywileje w dawnej Polsce. Studia z Dziejów Państwa i Prawa Polskiego. Vol. 11, pp. 19-38.

White, A. B. (1908). The Making of the English Constitution: 449-1485. New York: Knickerbocker Press.

Wilson, G. (Ed.) (1777). The Reports of Sir Edward Coke, Knt. J. London: Rivington and Sons. Vol. VII.

Zaborowski, S. (1507). Tractatus de natura jurium et bonorum regis et reformatione regni ac eius reipublicae regimine incipit feliciter, Cracoviae. 


\section{The Case of France: Vitality of the Republican Legal Tradition}

In my view, a prerequisite for the recognition of the unique nature of French constitutionalism is the multi-aspect analysis integrating legal, doctrinal and historical elements. I make analysis of the key sources for the French republican tradition: constitution, declarations of human and civil rights (beginning from the Declaration of Human and Civil Rights of 1789), adjudications of the courts, and opinions of constitutionalists and statesmen. The interpretation of these sources confirms vitality and continuity of the French republican tradition in which sovereignty of the nation and indivisibility and secularity of the republic play primary roles. Statism, centralism, and opposition to the strong position of the judiciary system are the principles determining the unique characteristics of the French constitutionalism. The Fifth Republic, established by Charles de Gaulle in 1958, did not change the French republican tradition. Contrary to the popular thesis, the constitution of 1958 did not establish a republican monarchy. De Gaulle embraced republican tradition defending it in a fierce dispute with Vichy and founding the Fifth Republic through the institutional revolution (including strong presidency, consolidation of executive power) conducted within the framework of its primary principles.

It is impossible to understand the uniqueness of French constitutionalism as long as the notions of republic and republican legal tradition are not discussed. At the same time they carry a particular meaning on the Seine and do not match their universal interpretations. According to the universal theories (Szlachta and Pietrzyk-Reeves, 2004; Filipowicz, Gładziuk and Józefowicz, 1995), republic is an alternative political system for the hereditary transfer of power (in this meaning elective monarchies were actually republics) or, in the extended version, they see the essence of republic in the existence of community of citizens gathered around laws and values. On the other hand, French republic is primarily the outcome of the French Revolution that established the new legitimation of power based on the specifically understood idea of the nation's sovereignty and molded its values in the stark contrast to the monarchist tradition (Quermonne, 1992). In Maurice Agulhon's view (Agulhon, 1990; Carcassonne, 2007; Luchaire and Cognac, 2008; Vimbert, 1992) being a republican primarily means being an advocate of the non-personal, non-hereditary, non-permanent, and non-arbitrary power and republic means identification with the tradition deriving from 1789.

1 University of Lodz. 


\subsection{Idea of the Sovereignty of the Nation and Its Ramifications}

Thus, in France, the notion "republic" conveys content different than that offered in the universal interpretations and means not only opposition to hereditary transmission of power but also its new legitimacy inspired by the philosophy developed by Jean-Jacques Rousseau; and, which is equally significant, some axiological project expressed in the Declaration of Human and Civil Rights, with a key role of the rules of the indivisibility and secularity of Republic. The sentence spoken by de Gaulle on the Square of Republic in September, 1958, just prior to the constitutional referendum, that republic was "the sovereignty of the people, the call of liberty, the hope of justice," (Maus, 1998) includes one of the most famous formulas determining the French understanding of the republic. This was repeated by Philippe Séguin (1988) in his famous speech delivered during the debate on the Maastricht Treaty ratification. He reminded that republic has a unique meaning in the French political tradition as it is not only a kind of the institutional system but a system of shared values molded by the heritage of revolution.

Republic is primarily a system of the commonly shared values that molded France into what it is still today in the eyes of the world. The Republic of France exists - just as the Republic of Rome once existed. This motto has remained the same since the very beginning: the sovereignty of the people, the call of liberty, the hope of justice (Séguin, 1988, pp.311-321).

Given such context, we will better understand the opinion offered by the outstanding French historian (Furet, 1989; Furet, 1994) who said that republic is the meaning of the French intellectual tradition that developed over the last two decades of the $19^{\text {th }}$ century, when the revolution accomplished its goals and became institutionalized. "Only the victory of republicans over monarchists in early years of the Third Republic is an ultimate proof of the victory of revolution in all the country" (Furet, 1994, p.10). In the essay “A Real End of the French Revolution” François Furet (1994) asserts that Jules Ferry, a teacher and a missionary of the 1789 principles, is a symbol rather than an instrument of that long and victorious campaign. Republic was ultimately molded when the legal institutionalization of the heritage of French Revolution was effected. Passing the act that recognized La Marseillaise as the national anthem (1879), recognition of 14 July as the national holiday by the Senate in 1880, and the 1875 constitutional amendment defining relations between public authorities, which excluded restoration of monarchy (Droin, 2009). Article 8 of the act on the organization of public organs was supplemented with the following sentence: "A republican form of the government may not be subject to any revision of the constitution. Members of the families that ruled in France are unelectable for the office of the President of Republic." (Godechot, 1970, p. 337). The 1884 amendment abolished public prayers following the inauguration of the new term of the assembly chambers (previous section 3 of article 1 of the aforementioned act set forth that "On the Sunday following the opening of 
the session, prayers shall be raised in churches to ask for support for the Assembly members in their work") (Godechot, 1970, p.334) and introduced a reform of Senate consisting in the deprivation non-dismissible senators of mandates and abolishment of preferences for rural districts (Bigaut, 2000).

Moreover, the two last decades of the 19th century witnessed introduction and development of the state and secular educational system developed by Jules Ferry. The last stage of the revolution institutionalization process comprised introduction of the radical separation of Church and State (Poulat, 1987; Remond, 1985).

Noteworthily, the republican nature of the state, secularity and indivisibility of Republic are - according to the Constitutional Council's ruling of 27 July 2006 inseparable from the French constitutional identity (Wojtyczek, 2008; Wójtowicz, 2010a; Wójtowicz, 2010b; Conseil-Constitutionnel, 2006). In this way the Constitutional Council confirmed that the heritage of French Revolution identifies core constitutional values. Before that, as early as in 1953, the Council of State highlighted the republican constitutional tradition, exposed in the Declaration of Human and Civilian Rights of 1789, in the preamble to the Constitution of 1946. Vimbert (1992) analyzed the notion "republican tradition" understood as a set of fundamental republican values confirmed by the historical experience and political practice.

Thus, it is no doubt that the French Republic is the country where citizens identify themselves with the heritage of the French Revolution. This marks a new beginning for the French statehood, which is manifested by the lack of any references in the republican constitutions to the heritage of the pre-revolution state. The Nation is defined as the community molded by history and culture, which is present in the German and Polish constitutional tradition, but rather a political community united around the heritage of the revolution. It is because of this reason that Philippe Séguin (1988) asserted that "a notion of the nation is stronger than a notion of Homeland". This explains the opening of the Republic to the people not molded in the French cultural environment but accept the heritage of the revolution as well as an open sense of citizenship based on the law of the world (Séguin, 1988). Chantal Delsol (2011) used to write in the similar spirit: "Republican France predominantly wished to maintain the unity between multicultural groups, embrace all the people but still be united”.

Republic also molded a new meaning of patriotism understood as an act of the people's disagreement with the conquest of France combined with the identification with republican values. "If we were to identify the day of its birth, I would say it was rather Valmy, when people took up arms, and not the Convention on the day after, when Assembly Members made decision to overthrow the monarchy" - Philippe Séguin (1988) said in the aforementioned speech. When Comité général d'études appointed by the Résistance surveyed its members, nearly all respondents associated republicanism with patriotism. An anonymous historian involved in the survey made the following conclusion: 
French people perceive republic as a system of all people, it is a great idea that heightened people's feelings in all national issues. It is Republic that repelled a threatening invasion in 1793, revived French feelings toward the enemy in 1870, managed to maintain French unity between 1914 and 1918, during the time of dreadful ordeals; its splendor is the splendor of our people and any defeat is our pain (Michel and Mirkine-Guetzévitch, 1954).

Moreover, the Republic molded by the heritage of the French Revolution, is rather the country of the nation than the community of citizens in the spirit of republican tradition derived from Ciceron. In the Ciceronian tradition "Republic is the matter of the Nation" and "the Nation is not just any group of people gathered by any means but a large group of people united by the recognition of the same law and the benefit of the shared living." (Szlachta and Pietrzyk-Reeves, 2004). Meanwhile, regarding the French Republic, the existence of the real community of citizens supporting specific laws and values is not as essential as the very fact that the people possess the state built on the values molded by the revolution heritage. This is why Gérard Baudson (1994) asserts that a concept of the state-nation is a voluntarist and political creation. "Thus a contract consists in establishing the state - therefore «resorting to the state» is something most essential. If the state-nation disappears, a social contract between citizens will be severed." (Baudson, 1994). It appears that the social isolation of de Gaulle and Résistance resulted considerably from the lack of tradition of national activity outside state structures.

The notions of the national sovereignty and volonté générale set forth in the Declaration of Human and Civil Rights (Articles III and VI), molded under the influence of Rousseau, are fundamental in the French republican tradition). Primarily, attention should be paid to the radicalism of the sovereignty transfer from the royal power onto the nation. Implementation of this rule resulted in dramatic ramifications as even the Constitution of 1791 - formally a monarchist one - challenged royal sovereignty. In his book on the French constitutionalism, Michel Morabito expressed a view that the Constitution of 1791 - pursuant to the 1789 ideals - challenged the royal sovereignty investing the king with a status of the people's representative. The monarch exercised the executive power and participated in exercising the legislative power but had no share in the constitutional power that solely depended on the legislative bodies representing people (Bourmaud and Morabito, 1996). Similarly, Adam Piasecki (1928) in his work on the parliamentarism of the Third Republic, concluded that: "In France, the transfer of sovereignty from the king onto the nation was revolutionary. The Constitution enacted by that Assembly, affixed with the declaration of human rights, is the manifestation of the theory of national sovereignty adopted in the hereditary monarchy." (Piasecki, 1928). Hence the basic difference between American and French revolutionary experience may be identified. In the first phase of American revolution, before the constitution of the Union was enacted, the people's right to participate in the legislation process or the ban on actions without the people representative's consent, were expressed in the Bill of Rights of the states of Virginia, Maryland and Massachusetts (Jellinek, 1905), while the French declaration challenged totally the 
monarchy's participation (negation of royal sovereignty) as well as the participation of intermediary organizations (such as corporations) stipulating that it was solely the people who could exercise the sovereign power.

Total exclusion of the monarchy from the area of sovereignty as early as in the initial phase of the French Revolution is not the only hallmark of the French understanding of people's sovereignty. More importantly, the idea of people's sovereignty developed under the influence of Rousseau's thought and was combined with the concept of the general will. According to the expression offered by Georg Jellinek (1905), a renown German lawyer, volonté générale, which "makes autonomous decisions about its boundaries and neither should nor may be limited by any power," (Jellinek, 1905) is absolutist in the thought of the author of the Social Contract. Thus, in Rousseau's view, sovereignty may solely be granted to the entire nation based on the complete ceding of individual rights to the nation-sovereign. (Jellinek, 1905; Boucher and Kelly, 2003; Pietrzyk-Revees, 2010). In his excellent sketch, Georg Jellinek (1905) expressed a view that the social contract developed by Rousseau and inspiring the Declaration includes only one clause: waiver of all individual rights in favor of society. "An individual retains not a single atom of law at the moment he becomes a member of the society. He is invested with all the rights by the volonté generale that unilaterally determines its boundaries and no power may or should restrict them. Even the ownership right is granted to an individual only with the state's consent." Jacques Maritain offers a similar opinion. In his view, a myth of the general will was used to transfer the separate and transcendental royal power to the nation that was also invested with a separate, transcendental, and absolute power (Maritain, 1993; Maritain, 1938). It is hard to reconcile the French republican tradition with Tocqueville's view where it is the individual's sovereignty that provides the basis for the nation's sovereignty at the last count (Tocqueville, 1996).

An absolutist understanding of the general will underlies the idea of the sovereignty of the act as the outcome of its expression. Thus the sovereignty of the act would mean its primacy, subject unlimitedness and a rule that it may not be subject to the review of constitutionality. A number of scholars, including J. Barthélemy, P. Duez, L. Duguit or M. Hauriou, put forward a proposal to review the constitutionality of acts, which would give citizens a right to institute such review in the event of violation of the constitutional rights of individuals. Yet such proposals were rejected as contradictory to the rules of Republic (Starzewski, 1928; Duez, 1929; Kubiak, 1993). Although provisions of the Declaration of Human and Civil Rights of 1789 were assumed to have a special status, but at the same time it was assumed that parliamentary obligations to effectuate them are of only moral nature since the resolutions passed in the Assembly are not subject to any verification as they express the general will. Noteworthily, the French republican tradition is not free from internal tensions. On the one hand, Declaration of 1789 recognizes freedom and ownership as natural human rights that are not subject to the statute of limitation. On the other hand, however, the nation's general will is absolutist and poses a threat to the rights of an individual in Rousseau's 
view. As we could see, advocates of the establishment of the review of constitutionality of acts had to address that question in the doctrinal dimension.

\subsection{Statism and Centralism}

Thus statism and centralism found solid support in the idea of the nation's sovereignty defined in such manner. The administrative monarchy was replaced by indivisible, unitary, and centralized republic. Tocqueville's works include a penetrating description of the continuity of administrative centralization since the decline of monarchy until mid-1800s (Tocqueville, 1994; Tocqueville, 1996). "Meanwhile, Revolution was against the monarchy and provincial institutions. Driven by the blind hatred, it destroyed everything that had been before its outbreak, both absolute power and any organizations that could weaken its force. Revolution was republican and centralist at the same time" (Tocqueville, 1996).

In the aforementioned paper, Jacques Maritain (1993) also discerned the continuity between monarchy and republic in this sphere since both political models did not tolerate the rights of fragmentary communities in the state.

The centralism of the French Republic remained its hallmark until modern times. Inability to reconcile the French model of republic with the federation and confederation model is quite obvious. The rigidity of French centralism is particularly noticeable in the list of the decentralization range in the unitary states. Notably, in early 1980s French Constitutional Council considerably limited the range of reforms aimed at the state's decentralization. Their resumption by president Chirac required constitutional amendments, which were implemented in 2003 (Favoreu and Philip, 2007; Ohnet 1996).

François Furet and Michel Morabito indicated that rejection of historical and more complex legitimization theories in the Declaration of Human and Civil Rights of 1789 must have inevitably led to the centralization and refusal to grant corporations public and state rights. François Furet (1994) wrote about that rejection during the crisis of the legitimization-concept monarchy, most strongly expressed in the works of Henri de Boulainvilliers, who emphasized the rights of intermediary organizations as the third - along with the royalty and nation - partner of the contract constituting France. On the other hand, Morabito mentioned a political concept developed by Malby, which recognized the nation as the compound community of social classes, putting stress on "the separate representation of different social classes inside the organ of the legislative power." (Morabito and Bourmaud, 1996). The idea of the nation's sovereignty and related rule of indivisibility has also a statist and centralist sense. Noteworthily, in their extensive commentary to the Constitution of the Fifth Republic, François Luchaire and Gérard Conac show its numerous ramifications. Indivisibility of the republic involves a unitary nature of the state, concentration of all normative power in the central state organs, a ban on investing local and regional 
communities with the competences in foreign policy affairs and, on the other hand, extensive competences of the government administration in the control over local self-governments. Authors highlight the fact that voting in the European Parliament elections is not the manifestation of sovereignty nor its delegation to the institutions that would be irreconcilable with the rule of indivisibility of the republic. Moreover - in their view - that rule results in the indivisibility of French nation, which means a ban on granting collective rights to the language, religious, and ethnic minorities (Luchaire and Conac, 2008).

It should be reminded that political rules of the French revolution were aimed to affect the rights of associations and corporations. In the extreme scenario, this meant a ban on establishing any associations or corporations. This is the provision of Article 1 of Loi Le Chapelier ("Le Chapelier Act") passed on 17 June 1791: "Since the abolition of all forms of corporations in the same class or occupation is one of the bases of the Constitution, it is forbidden to recreate such corporation under any pretext whatever" (Ptak and Kinstler, 1999). The Act banned any forms of corporations or associations of the "citizens of the same class or occupation," introduced fines for organizing such associations and prohibited administration to accept any addresses or petitions "written on behalf of the class or occupation" (Ptak and Kinstler, 1999). Assembly members were convinced they enforced the provisions of the French Constitution that recognized solely individual and people's rights. Corporation rights were recognized as a threat to the freedoms confirmed in the Declaration of Human and Civil Rights. Noteworthily, advocates of the corporation rights had to challenge the republican rules. René de La Tour du Pin, a precursor of the corporations-based political solutions, criticized the Declaration of Human and Civil Rights. In his view, the Declaration inspired liberalism and socialism and denied associations their rights recognizing only individuals and the nation (Strzeszewski, 1985). It also should not be surprising that Léon Duguit - the author of the solidarist concept of law - was extremely critical about the notion of the nation's sovereignty and republican legal rules and supported recognition of the rights of economic and professional corporations (Duguit, 1921).

Republic continued to deny the rights of associations and corporations even after the severe Le Chapelier Act had been repealed. The French political model prohibits investing professional and economic corporations with public rights, which is quite common in a large number of the European countries. Economic interests are represented exclusively inside the state structures, which explains a unique nature of the strongly statist model of the French capitalism. In the 1930s, a manner of expressing opinions about the bill became institutionalized in the form of the Economic Council. Initially, the Council acted on the basis of the presidential decree of January 1925 and then the act of 1936. In the Fourth Republic, the Council became a constitutional institution. Characteristically, it is this institution that Konstanty Grzybowski recognized - just like the Council of State - as an intermediary body limiting the power (Grzybowski, 1947). Given the lack of the real social bodies independent of the 
administration structures, it was the national institutions enjoying autonomy, such as the Council of State or the Economic Council, that were to check the political power. The latter one developed as a consultative institution. It is quite meaningful that no decision was made to invest it with a right to contribute to the development of the collective contracts. This was due to the alleged threat of the development of corporationism beyond the state's control (Grzybowski, 1947; Bloch, 2008).

\subsection{Opposition to the Rule of Judges}

It should also be noted that the republican tradition remained reserved toward a strong position and independence of the judiciary. One of the key rules of the French judicial system was the nomination for the position of judges done by the executive power (Perrot, 1991; Renoux, 1992). Notably, the French judiciary is not regarded as an independent power but as a function. The document produced by the Bardoux Committee, which is going to be thoroughly analyzed below, included one of the most interesting opinions about the crisis of the Third Republic and the conclusion that, unlike British, French judiciary has no position of independent power (Bardoux, 1936). It is recognized that judicial institutions are not intended to fulfil the idea of the nation's sovereignty, which is confirmed in the commentaries to the Constitution of the Fifth Republic (Carcassonne, 2007). Encroachment of the judiciary into legislative powers has always been regarded as a violation of the French republican model. This distrust was manifested in the speech delivered by Nicolas Sarkozy in July 2008 to begin the work on the revision of the Constitution (Documentation Francaise, 2008). A critical attitude toward a strong position of courts is also explained by an explicit objection to the judicial control over the constitutionality of acts (Starzewski, 1928; Kubiak, 1993; Garlicki, 1993). For the same reasons, a specific model of the administrative decisions control excluding any participation of the courts of general jurisdiction has been developed (Izdebski, 1990; Longchamps de Berier, 1962).

The idea of the nation's sovereignty - "the sovereignty of the will of all people" according to the definition offered by Carre de Malberg (1931) - has become the most crucial element of the continuity of the republican political system, legitimization of national authorities, and law (an act as a manifestation of volonté générale) (Vedel, 1990). In his thorough study on the Third Republic, Adam Piasecki (1928) emphasized that the notion of the nation's sovereignty, taken from the philosophy developed by Rousseau, provided the ideological basis for the constitution of republican France. Presumably, this was even the basis of all post-revolutionary constitutions except two periods: the Restoration between 1815 and 1830 and Vichy. The essential controversy between Republic and Restoration, discussed by Furet, should not be regarded as a journalistic formula since this is a good reflection of the fundamental difference between French monarchist and republican tradition. Only the Constitutional Charter from the period of Restoration, effective between 1815 and 1830, restored the 
monarchic legitimization rules and challenged the republican order. According to Adhémar Esmein, an outstanding French law expert, whose influence on teaching constitutional law in Europe is difficult to overestimate, "The most significant rule expressed by the Great Revolution is a principle of the nation's supremacy. Apart from the 1814 Chart, it was recognized and adopted as the basis in all - so much different - French constitutions" (Esmein, 2001). Thus a principle of the nation's sovereignty was the basis of the constitutional monarchy from the years 1789-1792, including the July Monarchy, Consulate period, and First and Second Empires. It is true that the republican tradition opposed Bonapartism and its personalized and arbitrary power. Yet it should be remembered that the empire adopted republican axiology along with the reference to the nation's sovereignty and spread the revolutionary political and legal heritage beyond the borders of France.

As the idea of the sovereignty of the nation was a primary element of the republican tradition, it was unavoidable that the question about the subject of sovereignty became one of the central constitutional issues. Regarding these issues, the republican tradition is diverse. Jacobin Republic and the Second Republic, albeit different in many respects, followed Rousseau's thought in their recognition of the direct democracy (First Republic), universality of civil-political rights and direct presidential elections (Constitution of 1848). For many years, the Third Republic associated republican principles with the parliament's supremacy, which was a reference to Sieyès who justified a monopoly of legislative power over the expression of sovereignty (Sieyès, 1989) in his famous writing, "What is the intermediary organization"?

The Republican constitutional doctrine developed by Adhemar Esmein provided a battery of arguments in support of such a political system. In Esmein's view, ethos and competence of the parliament members offered the best guarantee of respect for freedom and rational decisions beneficial to the public good. This outstanding lawyer openly referred to Montesquieu's thought and fiercely opposed any forms of sovereignty exercised directly by the nation. He rejected the institution of referendum as he perceived this as a populist threat and a risk of the destruction of law (Esmein, 1928). Contrary to the warnings De Gaulle gave in his historic speeches delivered in Bayeux and Espinal, the Fourth Republic followed those traditions. Article 3 of the Constitution of 1946 expressed this explicitly, setting forth that in all fields, except the Constitution, "nation exercises sovereignty through its representatives sitting in the National Assembly."

So what is the Fifth Republic that celebrated the 50th anniversary a few years ago? I am deeply convinced that the Constitution of 1958 proves vitality of the republican legal tradition. Contrary to a widespread opinion this is not the republican monarchy (Aron, 1997; Duverger, 1974). 


\subsection{The Fifth Republic - Institutional Revolution within the Framework of Republican Tradition}

De Gaulle grew up in a family whose members were monarchists but he advocated state patriotism and accepted republic as a permanent form of France's existence. His views matured under the influence of Maurice Barrès and evolved into the state patriotism that accepted the republican and nationalist writers, such as Charles Péguy, and the republic as such. De Gaulle's state patriotism was inclusive toward the diverse ideologies and sought consolidation of the state as a tool of the power of France (Duhamel, 1986). Thus De Gaulle did not think about combining the monarchist and republican traditions but rather the republic integrating a number of ideological families. During WWII, as the leader of Free France, he consistently and with great determination consolidated the republican tradition in the confrontation with Vichy. He had a right to write in his memoirs that in 1940 he "saved Republic from being buried" as it was abandoned by the vast majority of political elite (De Gaulle, 1968). Hence Retablissement de la legalite républicaine, proclaimed on 9 August 1944, was a logical consequence of the legal and national doctrine of Free France. In the years 1944-1946, as the prime minister of the provisional government, he transformed the republican principles into the foundations of post-war France. Owing to de Gaulle, the ideas of indivisibility, secularity, and the democratic and social state gained the status of the primary constitutional rules in the Constitutions of the Fourth and Fifth Republics. It should be stressed that de Gaulle totally accepted the rule of sovereignty of the nation as the principal one for the public order. Moreover, he was convinced that this rule should involve the democratization of France. This was a deep sense of the decision made in autumn 1945 on the constitutional referendum, which meant that the nation was granted the right to participate in pouvoir constituant. Thus, it is doubtless that de Gaulle consolidated the republican and constitutional identity of France. Therefore, the Fifth Republic could only be established as an institutional change in the republican axiology.

In the preamble to the Constitution of 1958, the French nation proclaimed attachment to the human rights and principles of the national sovereignty, just as set forth in the Declaration of 1789 and the preamble to the Constitution of 1946. Article 1, fundamental to the state's identity, defined France as the indivisible, secular, democratic, and social republic. The preamble and the three first articles of the constitution integrated all crucial republican threads (Constantinesco and Pierre-Caps, 2004).

At the same time, a deep institutional shift was effectuated. The Fifth Republic built a strong presidency, which received a mandate in the 1962 general elections; consolidated the executive power, which was then entrusted to two bodies, at the expense of the legislative power; but retained the government's accountability before the parliament and introduced direct democracy. The reform of 1958 provided tools that enabled France to pursue active national policy and retain a strong position in 
Europe. The speech Michel Debré delivered in a forum of Conseil d'État, claimed that "all French political power system must be reconstructed. Otherwise, there will be no state, no democracy and, consequently, no France and Republic.” Those words were a perfect manifestation of the reformatory intentions but also proved that French political elites did not abandon their superpower ambitions (Maus, 1998). Noteworthily, De Gaulle democratized the republican legal tradition according to the view that the supreme form of sovereignty is the sovereignty exercised directly by the nation. Theoretical arguments for abolishing the parliament's supremacy were developed by two outstanding lawyers: R. Carré de Malberg and René Capitant (Maus, 1998; Capitant, 1954). The Constitution of the Fifth Republic provided for a considerably wider range of the public vote: introduced general presidential elections, parliamentary elections due to the dissolution of the parliament, and, along with the constitutional referendum, a legislative referendum. It should be highlighted that on the day when the Fifth Republic was established, France was the first big European country that implemented the institution of referendum for making decisions crucial for the country, including constitutional amendments. Since that time referendum has become a constitutional instrument in Italy and other countries.

\subsection{Conclusions}

I would also like to draw attention to one negative aspect of the republican tradition - elimination of the solutions contrary to the French understanding of the nation's sovereignty and indivisibility of the republic. It was this specific understanding of sovereignty, as something that only the whole nation may exercise, that did not allow de Gaulle to transform the corporate ideas into practice and introduce the representatives of professions and business organizations to the Senate. De Gaulle endeavored to do this twice: in 1958 and 1969 - in the referendum. In both cases the opponents of his proposal highlighted its contradiction to the principle of indivisibility of the republic, which forbade any redistribution of sovereignty. The power of republican tradition did not allow for any evolution of the Supreme Judiciary Council into the corporative body. The Minister of Justice retained a right to appoint judges and supervise prosecutors. This is a manifestation of the traditional republican distrust of the judiciary. And last but not least, a unique control of the constitutionality of acts, established by the Fifth Republic, was adjusted to the republican tradition. A preventive control still predominates, which means that the law of the Republic may not be challenged ex post facto. The request for the constitutional review made by individual, provided for in the amendment of 2008, is not an open constitutional complaint and may be effectuated only when the request is addressed to the Constitutional Council through the Council of State or the Court of Cassation. Finally, the principle of indivisibility of the Republic guards the Unitarian French system and determines the limits for the increase of competence of the territorial self-government. 
Something I consider a negative aspect of the republican tradition may inspire studies on the function of the principal constitutional rules and identity. Undoubtedly, the principle of the sovereignty of the nation and indivisibility of the French Republic enjoy a unique status. They determine the internal cohesion of the constitution, its identity in external relations, and relationships between the French constitution and the European law. Thus the Fifth Republic proves vitality of the republican legal tradition.

\section{Bibliography}

Agulhon, M. (1990). Histoire de France. La République, 1880 à nos jours (vol. 5). Paris: Hachete. Aron, R. (1997). Esej o wolnościach. Warsaw: Fundacja Aletheia.

Bardoux, J. (1936). Comité Technique pour la Réforme de l’État, La France de demain. Son gouvernement, ses assemblées, sa justice. Paris: Sirey.

Baudson, G. (1994). L’Europe des Apatrides (p. 39). Paris: de Luynes.

Bigaut, C. (2000). Le réformisme constitutionnel en France (1789-2000). Paris: La Documentation française.

Bloch, M. (2008). Rachunek sumienia Francuza. In: M. Bloch, Dziwna klęska. Warsaw: Oficyna Naukowa.

Boucher, D. (2003). Rousseau. In D. Boucher and P. Kelly (Eds.), Political Thinkers: From Socrates to the Present. Oxford: Oxford University Press.

Capitant, R. (1954). Le conflit de la souveraineté parlementaire et de la souverainelepopulaire en France depuis la Libération, Revue Internationale d’Histoire politique et costitutionnelele, No. 14 avril-mai, pp.153-169.

Carcassonne, G. (2007). La Constitution. Paris: Éditions du Seuil.

Carré de Malberg, R. (1931). Considérations théoriques sur la question de la combinaison du référendum avec le parlementarisme. R.D.P.

Conseil-Constitutionnel, (2006). Decision $n^{\circ}$ 2006-540 DC dated July 27th 2006, http://www.conseilconstitutionnel.fr/conseil-constitutionnel/root/bank/download/2006540DCen2006_540dc. pdf, 27.09.2016.

Constantinesco, V. and Pierré-Caps S. (2004). Droit constitutionnel. Paris: Presses Universitaires de France.

De Gaulle, Ch. (1968). Pamiętniki wojenne. Vol. III. Warsaw: Wydawnictwo MON.

Delsol, Ch. (2011). Parę zapisków o republice francuskiej. In: Ch. Delsol, Idee republikańskie. Warsaw: Fundacja Res Publica.

Documentation Francaise, (2008). N. Sarkozy. Discours d’Epinal du 12 juillet 2007. In: Documentation Francaise, La Constitution française du 4 octobre 1958 après la révision de juillet 2008 (pp. 52-54). Paris: La Documentation Française.

Droin, N. (2009). Retour sur la loi constitutionnelle de 1884: contribution à une histoire de la limitation du pouvoir constituant derive. RFDC, No 80.

Duez, P. (1929). Le contrôle juridictionnel de la constitutionnalité des lois en France. Comment il convient de poser la question. In: M. Hauriou, Mélanges. Paris: Sirey.

Duguit, L. (1921). Traité de droit constitutionnel chapters V - Le problème de L'état) and VI - La conception réaliste de L'état. Vol 1. Paris: Ancienne Librairie Fontemoing and Cie.

Duhamel, O. (1986). Discours de Bayeux 16 juin 1946. In: F. Châtelet, O. Duhamel and E. Plisier (Eds.), Dictionnaire des œuvres politiques. Paris: Presses Universitaires de France

Duverger, M. (1974). La monarchie républicaine (ou comment les démocraties se donnent des rois). Paris: Laffont. 
Esmein, A. (1928). Traite de droit constitutionnel. Paris: Sirey.

Favoreu, L. and Philip, L. (2007). Les grands textes du Conseil Constitutionnel. Paris: Dalloz.

Filipowicz, S, Gładziuk, N. and Józefowicz, S. (1995), Republika. Rozważania o przemianach archetypu. Warsaw: ISP PAN.

Furet, F. (1989). La Révolution: de Turgot à Jules Ferry, 1770-1880. Paris, Hachette.

Furet, F. (1994). Prawdziwy koniec rewolucji francuskiej. Kraków: Społeczny Instytut Wydawniczy Znak.

Garlicki, L. (1993). Rada Konstytucyjna a ochrona praw jednostki we Francji. Warsaw: Wydawnictwo Sejmowe.

Godechot, J. (1970). Les Constitutions de la France depuis 1789. Paris: Garnier-Flammarion.

Grzybowski, K. (1947). Demokracja francuska. Kraków: Czytelnik.

Izdebski, H. (1990). Francja. In L. Garlicki (Ed.), Sądownictwo administracyjne w Europie Zachodniej. Warsaw: PWN.

Jellinek, G. (1905). Deklaracja praw człowieka i obywatela. Warsaw: Księgarnia Powszechna.

Kubiak, A. (1993). Francuska koncepcja kontroli konstytucyjności ustaw. Gdańsk: Uniwersytet Gdański.

Longchamps de Bérier, F. (1962). Kontrola Rady Stanu nad administracją we Francji. Kontrola Państwowa, No 5.

Luchaire, F. and Conac, G. (Eds.) (2008). La Constitution de la République Française. Analyses et commentaires. Paris: Economica.

Maritain, J. (1938). Trzej reformatorzy: Luter, Descartes, Rousseau. Warsaw: Verbum.

Maritain, J. (1993). Człowiek i państwo. Kraków: Społeczny Instytut Wydawniczy Znak.

Maus, D. (1998). Discours prononcé par le général de Gaulle, place de la République, le 4 septembre 1958. In Maus D., Les grands textes de la pratique institutionnelle de la Ve République. Paris: La Documentation Française.

Maus, D. (1998). Discour de M. Michel Debré devant le Conseil d’Etat le 27 août 1958. In Maus D., Les grands textes de la pratique institutionnelle de la Ve République (pp. 2-8). Paris: La Documentation Française.

Michel, H. and Mirkine-Guetzévitch, B. (1954). Les idées politiques et sociales de la Résistance (p. 47). Paris: Presses Universitaires de France.

Morabito, M. and Bourmaud D. (1996). Historia konstytucyjna i polityczna Francji (1789-1958). Temida, No 2.

Ohnet, J.-M. (1996). Histoire de la décentralisation française. Paris: L.G.D.J.

Perrot, R. (1991). Le conseil supérieur de la magistrature. La Justice, „Cahiers Français”, La Documentation française, No 251.

Piasecki, A. (1928). O parlamentaryzmie III Republiki. Poznań: Fiszer i Majewski.

Pietrzyk-Revees, D. (2010). Republikańska koncepcja umowy społecznej. In Z. Rau, and M. Chmieliński (Eds.), Umowa społeczna i jej krytycy w myśli politycznej i prawnej. Warsaw: Scholar.

Poulat, E. (1987). Liberté, laïcité. La guerre des deux France et le principe de la modernité. Paris: Le Cerf-Cujas.

Ptak, M. J. and Kinstler, M. (1999). Ustawa Le Chapelier z 14 czerwca 1791 r. In Ptak M. J. and Kinstler M. (Eds.), Powszechna historia państwa i prawa. Wrocław: Wydawnictwo Uniwersytetu Wroctawskiego.

Quermonne, J. L. (1992), République. In O. Duhamel and Y. Mény (Eds.), Dictionnaire constitutionnel. Paris: Presses Universitaires de France.

Rémond, R. (1985). L'anticléricalisme en France, de 1815 à nos jours. Brussels: Complexe.

Renoux, T. S. (1992). L'autorité judiciaire. In D. Maus, I. Favereu and J.-L. Parodi, L'écriture de la Constitution de 1958. Acte du colloque du XXX anniversaire Aix-en-Provence 8, 9, 10 septembre 1988. Paris: Economica. 
Séguin, P. (1988). Oui, nous voulons l'Europe, mais debout. In M. Mopin, Les grands débats parlementaires de 1875 à nos jours (pp. 311-321). Paris: La Documentation française

Sieyès, J. (1989). Qu'est-ce que le Tiers État? Paris: Flammarion.

Starzewski, M. (1928). Środki zabezpieczenia prawnego konstytucyjności ustaw. Krakow: Krakowska Spótdzielnia Wydawnicza.

Starzewski, M. (1928). Środki zabezpieczenia prawnego konstytucyjności ustaw. Krakow: Krakowska Spótdzielnia Wydawnicza.

Strzeszewski, C. (1985). Katolicka nauka społeczna. Warsaw: ODISS.

Szlachta, B. and Pietrzyk-Reeves, D. (2004). Republika, In B. Szlachta (Ed.), Stownik społeczny. Krakow: WAM.

Tocqueville, A. (1996). 0 demokracji w Ameryce. Vol. I. Krakow: Społeczny Instytut Wydawniczy Znak. Tocqueville, A. (1994). Dawny ustrój i Rewolucja. Krakow: Społeczny Instytut Wydawniczy Znak. Wojtyczek, K. (2008). Europeizacja V Republiki Francuskiej. Przegląd Sejmowy, No 5.

Wójtowicz, K. (2010a). Rola sądów konstytucyjnych w tworzeniu zintegrowanej europejskiej przestrzeni prawnej. In A. Frąckowiak-Adamska and R. Grzeszczak (Eds.), Europejska przestrzeń sądowa. L'espace judiciarie européen. Wrocław: Wydawnictwo Uniwersytetu Wrocławskiego.

Wójtowicz, K. (2010b). Poszanowanie tożsamości konstytucyjnej państw członkowskich Unii Europejskiej. Przegląd Sejmowy, No 4.

Vedel, G. (1990). La continuité constitutionnelle en France de 1789 à 1989, RFDC 1990, № 1. Vimbert, Ch. (1992). La tradition républicain en droit public français. Paris: LGDG. 
Ferenc Hörcher ${ }^{1}$

\title{
7 Is the Historical Constitution of Hungary Still a Living Tradition? A Proposal for Reinterpretation
}

\begin{abstract}
A similar ideal constant is the constitution, the moral territory and property, as it were, of Hungarians. This is again a fix point in the universe. The constitution can be violated a thousand times, and it is possible to govern without it or against it. But even if this goes on for centuries, a true Hungarian will nevertheless regard the constitution as living and valid (Babits, 1939, 70).
\end{abstract}

\subsection{The Historical Constitution of Hungary: A Diffuse Concept}

To write about the historical constitution (történeti alkotmány) of Hungary is not easy for more than one reason. First of all, because the meaning of the term is not readily detectable: it is not a well-defined corpus of written legal norms. Hungarian legal and political life was until the end of the $19^{\text {th }}$ century based on (written or unwritten) customary law, and its constitutionality was not an exception to that (Rady, 2015); second, because its birth is unclear. Although one of its acclaimed cornerstones was a rather early legal document, the Golden Bull from 1222, often compared in this tradition to the Magna Charta's role in the constitutional tradition of the United Kingdom (Hantos, 1904), the idea that this piece and other legal norms, statues, decrees and their legal principles and customary procedures could be taken together as the body of a constitution took a long time to take hold, from the early $16^{\text {th }}$ century, when István Werbőczy collected the private laws of the country, ${ }^{2}$ through the early seventeenth century revolt of István Bocskai, whose arguments in defence of his activity was based on quasi-constitutional grounds (Zászkaliczky, 2012), up until the short $18^{\text {th }}$ century, when the estates actually worked out the system which used as one of its central pillars the idea of the "ancient constitution" (avita constitutio, ösi alkotmány). Accordingly, In László Péter's interpretation, the historical constitution is in fact in power only from the end of the eighteenth century: "Between 1790 and 1918, the nobility's ancient constitution, avita constitutio, provided a potent and enduring source of a shared Hungarian past” (Péter, 2012b, p.191).

1 Pázmány Péter Catholic University and Hungarian Academy of Science.

2 The privatly published law collection, which had no official status, gained authority through the constant reference to it in the courtrooms and local and national diet chambers of the country. There is a recent English translation of its text with commentaries (Stephen Werbőczy, 2005, usually referred to simply as Tripartitum). 
While the birthdate of the constitution is still debated, there is an agreement among scholars that it was at the end of the eighteenth century that an awareness of the constitutional practice of the country awakened, and that the short interval of political upheaval, following the death of Joseph II and the outbreak of the French Revolution, resulted in an unprecedented outburst of constitutional debate and constitutional activity as well, during the diets of 1790-1791, and 1792 (Szijártó, 2005) (Concha, 2005). Inspired by the legal theories of the Enlightenment (in particular by Montesquieu, whose reference to Hungary made him a popular author, and his opus magnum, The Spirit of the Laws, "the bible for the nobility"3 (Péter, 2012, p.156), real efforts were made to reform the constitutional settings of the country, resulting in the composition of long documents of reform legislation plans. The Committees of the diet put together long lists of suggestions (called operatum) in the fields of commerce, law, urbarium, and so on, which were meant to be discussed during the next diet. However for political reasons they were sent to the archives of the chancelleries, and were only reconsidered four decades later, in 1831 and 1832. In spite of this cancellation of the fulfilment of constitutional reforms, the hot constitutional debates of the early 1790s represent the creation of a public constitutional discourse in Hungary.

A further point which makes the task so challenging is the so called doctrine of the Holy Crown. This idea was claimed to originate in medieval times, and to consist in the view that "from the Middle Ages the king and the diet (later parliament) have jointly possessed the Holy Crown, in which Hungary's legal and political sovereignty resides" (Péter, 2012c, p.148). The textual basis of the doctrine is Section I Tit 4 (1) of the Tripartitum, but the doctrine depends on a contested interpretation of the text. According to Péter, who is rather critical of the reading which substantiates the doctrine, "In Werbőczy's view, the nobility through its customary rights shared, together with the counties and the diet, power with the crown, rather than with the king in the crown" (Péter, 2012c, p.149). According to his reconstruction of the growth of the doctrine, it appeared sometimes in the early $19^{\text {th }}$ century and became more fuly elaborated in the 1830s. It was refined by legal historians and political theorists, including Imre Hajnik, Győző Concha and Ákos Timon, but "the most effective promoter of the doctrine" was "the eloquent Count Albert Apponyi” (Péter, 2012c, p.150). Interestingly the doctrine survived the disintegration of the original Hungarian state, of the Habsburg Empire and the devastating effects of the Trianon peace treaty (1920), which left the kingdom of Hungary one of the losers of the Great War, without many of its inhabitants and territories, and served therefore as one of the pillars of the official neo-baroque ideology

3 This is Montesquieu's famous reference to the Hungarian nobility: "The house of Austria has ever used her endeavours to oppress the Hungarian nobility; little thinking how serviceable that very nobility would be one day to her. She would have drained their country of money, of which they had no plenty; but took no notice of the men, with whom it abounded" (Montesquieu, 1777, Vol. 1. Book VIII, ch. 9). 
the interwar Hungarian regime, called Horthy-era (Péter, 2012d). During its long and troubled history, the doctrine of the Holy Crown served as the foundation stone of Hungarian exceptionalism, an idea that Hungarian history and the constitution that grew out of it, in some ways represented a unique colour in European history, a kind of Sonderweg, which excludes any easy comparison with other countries' historical achievements. The doctrine itself lost its relevance during the Communist takeover, but it was reborn in late Kádárism (1970s and 1980s) and at the time of the transition (1989-1990), and it still embodies a virulent political subculture in Hungary.

After we have considered these difficulties, we can define the aims of the present paper. It is going to be an exercise both in the history of political thought and in normative political philosophy. The aim is to give a longue durée account of the constitution, by which we can summarise some of the main achievements and a few of the main failures of its history. Before that, there will be a theoretical section, which examines the way a reconstruction of constitutional thought may reveal a more generally Hungarian "constitutional culture," which can serve for the abstraction of a constitutional philosophy. By drawing conclusions from its failures and achievements the paper will undertake to propose a philosophical reinterpretation of the meaning of the constitution, connecting it with some parts of the new Fundamental Law, but trying to avoid the legitimacy issue of the latter.

\subsection{Political Thought, Constitutional Culture and the "Philoso- phy" of the Constitution}

Political thought is closely related to political action and agency and political action is in turn closely related to human ideas and even ideology. The history of political thought is, therefore, a reconstruction of thought to shed light on human action and agency. ${ }^{4}$ It is therefore not separable from political history. If you want to understand what a certain political statement in the past really meant, you have to understand how it was related to human action. The way a historical protagonist thinks about a political situation does not necessarily determine the way she reacts, but knowing how she thought about it is most probably very informative of the possible choices she could make of potential actions. So the reconstruction that is made possible by the history of political thought of the thought of political agents might turn out to be quite useful for political historians as well. The mutual connection between the history of political thought and political history is therefore rather close.

4 In addition to the writings rooted in Cambridge-style history of political thought, the following methodological argument was inspired by R.G. Collingwood and Michael Oakeshott. 
However, there is a further dimension to the nature of political thought to consider. The concept of rational choice is not always the best description of how political agents decide and act. Certainly emotions and other irrational impulses also have an important role in the decision making process of political agents. And crucially, as in other types of activity, there is a large field of political action, where people behave in an unreflective manner. Routine is an important part of politics, and social routine is directed by individual habits and custom. Politicians have a large reservoir of experience of the past, and they can rely on it when they choose. When they act out of routine, they rely on this unreflective, habituated knowledge of how to do things. In other words, they rely on what their experiences and education, on their character (as it was called from the ancients up to the end of the early modern period) or, as Bourdieu would call it, on their habitus. Character - and habitus - formation is mostly the responsibility of the agent's environment, it depends on the kind of exchanges one earlier had with others and with the hard facts of the world, and the way they configured the agent's character. In the case of politics, this external environment reflected in the character or habitus is rightly considered the specific political culture of the specific community.

The analysis of linguistic utterances to reconstruct the discourse is the primary aim of the history of political thought. It should, therefore, shed light not only on the way people acted, but also on the way agents' ideas and actions interacted, and were already preconditioned by the particular political culture of their environment. In other words, expressed human thoughts can help the interpreter to reconstruct the outline of the particular political culture the given individual was formed by, and was also part of. This claim is based on the Heidegger - and Wittgenstein - inspired recognition that a political speaker/author is overtaken by the language she uses. But language is only one form of the way tradition actually controls the agent's behaviour and thinking: culture manifests itself in a number of other ways, too, some of which are not even identified by the agent, who, paradoxically, displays the features of a common political culture in the very moment when she becomes an autonomous personality, with her own style of thinking and action. By comparing the linguistic performances of different members of the same political culture history of political thought hopes to distinguish what is characteristically personal, and what belongs to a common political culture characteristic of the community to which the agent belongs.

The following analysis of the Hungarian historical constitution develops from the assumption that it is not simply a collection of written laws or well defined norms, but a certain political culture, a constitutional culture (Sólyom, 2015). Therefore, the aim of the analysis is not simply to make sense of the ideas of particular political agents - for example, those of the particular members of the nobility who forced Andrew II to issue the Golden Bull, or of Stephan Werböczy when he collected the civil law customs of his country, or Bocskai or Rákóczi rebelling against the Habsburg monarch pleading to the constitutional tradition, but rather to understand what exactly did 
it mean to refer to the historical constitution for any members of the political community. A constitutional culture will certainly prefigure the political agents. In other words, through a short analysis of its vocabulary, this essay would like to outline the constitutional culture of the historical constitution.

\subsection{Historical Layers of Constitutional Life in Hungary}

If we want to reconstruct the historical development of constitutional life, which includes constitutional thought and action in Hungary, we have to understand that one of its central elements is its traditional nature. For the historical constitution is principally a way of thinking that relies on the wisdom of earlier precedents to gain insight into constitutional questions of the present. This attachment to tradition is the more surprising that this was a country characterised by a rather discontinuous and staggered history, resulting in an uneven development of constitutional thought. Its birth was not signalled at once, but may be traced back retrospectively, and therefore the tradition's starting point fades into the mist of time immemorial. ${ }^{5}$ Its application requires a backward looking technique of legal argumentation, and such a procedural obligation means that new contexts will necessarily reconfigure the past, in order to update the actual content of the law. In other words, history builds layers upon layers, in an unplanned, spontaneous manner. As this spontaneous growth results in a rather uneven development, there is no point in a paper like this to try to tell it as a continuous story in a full, rounded narrative. Rather, we will try to plumb testholes here: samples from different political contexts, in a chronological order, I order to show the full dimension of the constitutional architecture, with all its different historical layers.

\subsection{Founding the Historical Constitution? The Golden Bull}

The Golden Bull is a "decretum, a royal charter of liberties” (Péter, 2012e, p.115), issued by King Andrew II of Hungary in $1222^{6}$ (Zsoldos Attila, 2011) (Rady, 2014). We know it from a letter by the king to Pope Honorius III that a large crowd of the nobility demanded "that he should confirm the liberties that St Stephen, the holy king, had granted to the nobility.” In other words, in its very starting point the constitutional practice is backward looking, using a historical argument. The demand was based on a suspicion that Andrew II was responsible for "harmful practices which amounted

5 It is noteworthy that a reference to times immemorial is a common element of the Hungarian and the British constitutional thought (Pocock, 1987).

6 The text of the decree is by now available in English and Latin (Werboczy, 2005). 
to abuses of royal authority.” The demanded confirmation included privileges, such as "the exemption from taxes, limits on the military duties of the nobles and their right not to be arrested without first being summoned and sentenced by due judicial process." This is again important because it gives ample proof that the subjects of the decretum belong to an exceptional minority, the nobles who can claim particular exemptions and privileges on a traditional basis. This was explained by the fact that the distinction of noble and non-noble assigned the chance to participate in the political life of the country, and participation granted the "ancient" liberties to those who actually contributed to the common good. Through this decretum the nobles wanted to get guarantees to defend their position against the new barons, and therefore the Golden Bull was not interested in trying to weaken royal power. Due to the fact that the specific constitutional standing of the nobility has proven to be surprisingly stable during the centuries, one of the most important characteristics of the Hungarian constitution is that it is traditionally a noblemen's constitution. A further point of the Golden Bull that needs to be stressed is the fact that it only reaffirmed what is called by Joachim Bahlcke the culture of liberty (Libertaskultur): a political culture where the participation in the political system was based on the liberties that were donated by the king as an expression of personal trust (Balcke, 2005) (Zászkaliczky, 2012) (Varga, 2004). This centrality of the notion of liberty became again a key notion of constitutional thinking in Hungary, where the special privileges of the individual noblemen came to mean first the liberty of the order or estate of nobles, as a whole, and later that of the country (ország), the political community of the Hungarians as instituted by the constitutional tradition itself.

\subsection{Stephen Werbőczy}

As we have seen, the Golden Bull already referred to liberty in the past tense, as something which was secured by the great king earlier, this decretum itself became the most important reference point later when, quite irregularly, political debates were fought with arguments which referred to earlier customs of royal privileges to the nobles as precedents. Martyn Rady, in a paper dedicated to its relevance, makes the following, seemingly contradictory claims: "In the century following its issue, all mention of the Golden Bull disappeared," and yet "Perhaps indeed, as Henrik Marczali slyly observed, the whole history of Hungary's constitution was, like Bishop Stubbs's observation on Magna Carta, a commentary on the Golden Bull” (Rady, 2014) (Marczali, 1896, p.79). Yet this contradiction dissolves as soon as Rady makes it obvious that references to the Golden Bull were sporadic in the first decades because the text of it turned out to be too radical, including the famous resistance clause.

However, this backward referencing, which is already characteristic of the language of the Golden Bull, becomes notorious with Stephen Werbőczy's painstaking efforts to put down into a legal collections the customary law of Hungary. The 
connection between the Golden Bull as the precedent, and the Tripartitum, as the collection came to be called, as the interpretation of it, is made obvious by Rady, too: "The Golden Bull was additionally used by the lawyer and politician, Stephen Werböczy, to lend the semblance of antiquity to what he claimed were the inviolable privileges of the Hungarian nobility" (Rady, 2014, p.106). In the modern English translation of the collection of customary norms, which the protonotary of the courts of the judge royal and voivode of Transylvania presented to the diet of 1514, and as judge of the personalis (személynök) published privately in Vienna in 1517, without winning the official consent of the king, became the most important reference point itself, for later discussions of the content of the ancient constitution of Hungary (Rady, 2005, xxvii). "Its principles and provision laid down the substantive law of noble landholding, the special privileges enjoyed by the Hungarian nobility, and the practices and procedures to be followed by the royal courts” (Rady, 2005, p.xxvii). Werbőczy's collection is important because it remained the most notorious point of reference whenever issues of constitutional significance were brought up. In this way, it was regarded as the final authority, even if the exact meaning of its provisions were sometimes hotly debated. But it served as a written proof of what the consuetudo or in more general terms the law of Hungary contained. Péter László is ready to regard it, therefore as a handy summary of "Hungary's ancient constitution," perhaps not meant as such in the time of its creation, but regarded as such by all participants of Hungarian political and legal life (Péter, 2005, p.xiii). This could happen because of the continuous labour invested into the interpretation and reinterpretation of it, allowed by the specific nature of customary law. It allowed legal practitioners to regard law as "not made or created" but as "ius, right, which exists as the approved habits and usages of the commune” (Péter, 2005, p.xiv). In other words, the Tripartitum enjoyed a special status, an authority of the law, coming from its continuous use by the whole community, transforming it into "the tacitus consensus populi," the tacit consensus of the populace, which of course meant the nobility only, and its relation to the Crown "a kind of contract between the king and the diet of the ország (noble community)" (Péter, 2005, p.xv). This contract had two partners, the crown and the totum corpus of the ország, the latter offering constant loyalty to and armed defence to the Crown in times of emergency, the latter providing the liberties of the nobles, which could be enforced according to the resistance clause six of Chapter Nine in the First Part of the Tripartitum. This clause referred back to the Golden Bull, claiming that if the ancient privileges were damaged, the nobles (as a corpus) had the "liberty to resist and oppose him without the taint of infidelity" (Werboczy, 2005, p.57.) One should not wonder that in the $18^{\text {th }}$ century, when Hungarians learned from the legal theorists of the Enlightenment that what they possessed was a kind of contract, on which however a whole edifice, a "system of a 'constitution"” was built, they became so obsessed with it, that they were not ready to give it up in the wholly changed atmosphere of the $19^{\text {th }}$ century as well, when as a result of the settlement between the two countries, the Kingdom of Hungary coalesced with the Habsburg territories of Austria, they still kept 
it, and it remained the source of constitutional ideology up until the first written constitution drawn by the communists after the second world war.

\subsection{Stephen Bocskai}

The special status of the Tripartitum is partly due to a further fact: during the centuries it came to serve as the basis of reference for the fight for independence of the country. After the Turkish invasion when the country was cut into three parts, we see constant struggle in the country between rivals to get the Hungarian throne. One the one side we find the Catholic Habsburg rulers, who claimed power mostly over the North-Western territory, while Hungarian and Transylvanian candidates fought for the independence of the country. One of the contenders was Stephen Bocskai (15571606), a protestant nobleman, who served in the Habsburg chancellery in Prague and Vienna and later became prince of Transylvania, the eastern part of the territory, present day part of Romania. His fight for the crown represents in paradigmatic form the agonistic opposition between country (ország) and court (udvar), in a situation when the nationality and the religious affiliation of the royal family is different from the main body of the nobility. While the Habsburgs were interested in widening their control over the whole territory, the Transylvanian Hungarians played a strategic game of oscillating between the power-centres of Vienna and Constantinople. They tried to win support against that power which seemed to be momentarily the more dangerous, in order to preserve some kind of a balance of power between the three parts of the country. The conflict over sovereignty between the Habsburg court and the Transylvanian princely court was, of course, coloured by a confessional antagonism: the reformation proved to be very successful in the Eastern and Northern part of the country, which made a counter-reformation seem quite necessary for the Catholic Habsburg dynasty. Both of these dimensions of the conflict (territorial control, confessional rivalry) were present in the ideological basis of István Bocskai's movement, which led to a short, but quite successful War of Independence in 1605. As a result of it he could negotiate on both sides, with the Turks as well as with the Habsburgs.

When analysing his political thought, in the historiographical tradition Bocskai is represented either as one who was relying heavily on the resistance clause of the Golden Bull, as it was transmitted by Werbőczy ${ }^{7}$, or as using the Golden Bull only as a cover up in the ideological warfare, while his really radical idea of armed resistance was rooted in a Calvinist reformed theological conviction. ${ }^{8}$ It is unquestionable that

7 Benedek Varga attributes roughly this position to historians like Ferenc Eckhart, Imre Révész and Gyula Szekfü (Varga, 2006, p.29).

8 Varga lists in this camp Kálmán Benda, László Makkai and with a slightly different orientation, Katalin Péter. 
the political system of estates, often called feudalism, incorporated into its own practice the defence of religious freedom as an ancient right and liberty. It was Bocskai who firmly established the final argument of rebellious resistance against the unconstitutional measures of the court, which came to characterise Hungarian politics time and again afterwards for three centuries, resulting in quite a number of lost fights of liberty against more powerful monarchs. But Bocskai himself succeeded to show that religious freedom can also be defended by reclaiming ancient rights. The estates learnt that it is rewarding ideologically if they refer back to their ancient rights, and as a result ever since they kept referring to the Golden Bull and the Tripartitum, which helped the latter document to gain unparalleled position in Hungary's constitutional life: it came to be seen as the main form of expression of the Hungarian feudal ideology, of the ancient constitution (Zászkaliczky, 2015, p.22). Bocskai's innovation led to an ideological unification as well: the political theology of Hungarian Protestantism integrated the paradigm of ancient constitutionalism, which on the other hand had an impact on this latter discourse as well: the resistance clause won an unparalleled priority in the constitutional thought of the country, which indicated that in case the Habsburg's keep enforcing their own vision of politics (i.e., a centralised empire with a united legal system), the Hungarians will never give up their fights to adhere to their own constitutional tradition, which included the right to resistance as well (Zászkaliczky, 2012b). After expelling the Turks from the central parts of the territory of the Kingdom of Hungary, the Habsburgs could successfully enforce their will, and let the Hungarians exclude from the body of constitutional norms the resistance clause; but the idea itself remained, and was easily available even in the political turmoil of 1848. To sum up: "the Bocskai revolt and its legal results brought about the integration and final emancipation of the Protestant Churches into the estates polity (Ständestaat) as well as the emancipation of the political theology of Hungarian Protestantism, the first steps towards a modern political culture” (Zászkaliczky, 2012, p.294).

\subsection{Transforming and Reflecting Upon the Historical Constitution: The Eighteenth Century}

While the political struggle in the $17^{\text {th }}$ century was largely fought along confessional lines, the $18^{\text {th }}$ century saw in the Kingdom of Hungary a transformation of political life, leading from what is called in the historiography "confessional" estates polity to a "constitutional” estates polity (ständisches Konstitutionalismus) (Szijártó, 2012).9 While earlier the confessional confrontation could have been manipulated by the

9 I am grateful to Professor Szijártó for the email correspondence in which he suggested to provide the German equivalent for the latter expression. 
ruler, now the confrontation shifted to the opposition of the diet and the ourt. In questions of defending their "constitutionally guaranteed" privileges, the nobility was united, independently of their confessional identity. It is also interesting that in this new situation the lower nobility (bene possessionati) gained the upper hand from the aristocracy, which earlier was regarded as pars sanior (Szijártó, 2012, pp.39, 47). It was in this context, and as a result of learning from Montesquieu that the estates of the nobility were actually in possession of a constitution, that actual references to the term constitution appeared in the constitutional legal discourse. They learnt it from The Spirit of the laws that a system of rights and privileges is nothing less but a constitution. As László Péter put it: “They discovered, not unlike Molière’s burgher who learnt that he was speaking 'prose', that what they possesses was a 'constitution' rather than just a collection of customary rights” (Péter, 2012, p.156). It is also from this period that the dualist character of the constitutional arrangement becomes obvious - while earlier king and the diet worked hard to cooperate and to find compromises, from this time ont here is a constant struggle between them over questions of souvereignty. Although it was undebatable that the Crown, meaning in this case simply the king was superior to the diet, the king was obliged by custom to negotiate with the diet, which latter had certain techniques of enforcing that their views be taken into account by the king (including the tactical use of their votes for more tax or military support).

It is from the end of the 18th century that references to a venerable ancient constitution began to be used. Szijárto specifically refers to the diet of 1790 , when the deputy instructions of the deputies of Somogy county explicitly use the term constitution. ${ }^{10}$ He also claims that the analysis of the ceremonial speeches of the diet signal the latin word „constitutio” (speeches at the diet in those years were mostly given in latin) from 1792, in which year both the primate József Batthyány, and the personalis József Ürményi used it, the former calling attention to the aim of preserving the “ancient constitution” (Szijártó, 2015, p.27). Péter László refers to Article X of 1790 as "the first statutory reference to the 'constitution"”. ${ }^{11}$

Part of the reason for this transformation of the terminology might have been that the direct state intervention with the aim of radically transforming the constitutional arrangements by king Joseph II provoked strong resistance. No doubt this unprecedented conflict with the king, who withdrew most of his reforms on his deathbed, as well as the American experience, the Dutch and French revolutions, which introduced hot debates of constitutionalism on an international scale, took part in the

10 Beside his own findings, Szijártó also refers to (Melhárd Gyula, 1906, p.60.) He admits that in these texts the expression used is sarkalatos alkotmány (appr. cardinal constitution).

11 The Article „enacted that the kingdom had to be 'ruled and governed according to its own laws and customs' because it had its own character and constitution (propriam habens consistentiam et constitutionem)" (Péter, 2012b, p.193). 
sequel in the first half of the last decade of the 18th century, which was an unprecedented fermentation of constitutional thought in Hungary. One should not underestimate the relevance of this phenomenon because of the seemingly dead end of all these efforts when the king, using the Martinovics conspiracy as a shop window case, closed down all possibilities of constitutional reforms. We are reminded by Szijártó that the simple fact that political participation was so high is a secure proof that this turn towards the constitutional discourse within the institutional framework of the estates, mainly using the country assemblies and the national diet, prepared the way for a more modern democratic political culture. In this respect Szijártó himself refers to the views of other researchers like Ambrus Miskolczy and Károly Kecskeméti, who again emphasise the importance of the late 18th century developments (Szijártó, 2015, p.27; Miskolczy, 2005, p.199; Hörcher, 2016). However, Szijártó offers a few cautionary remarks as well. First that this special kind of "constitutionalism" did not have a democratic content in the modern sense of the term, and in fact the aabsolutist opponent of this movement, the Habsburg government, was more forward-looking in a number of issues, including its peasant policies and religious toleration. And, second, that although the sharp political conflicts of the dualist model foreshadowed the kind of party politics which is characteristic of modern parliamentary systems, in fact a lot was lost with the eclipse of a cooperative model between court and country, characteristic of the earlier system, and still in work in the first half of the 18th century (Szijártó, 2012, p.48). We shall have to return to this apparent contradiction in our assessment of the failures and achievements of the historical constitution.

\subsection{The Golden Age of Historical Constitutionalism: The Nine- teenth Century}

If the $18^{\text {th }}$ century created the preconditions of a thriving constitutional life in the country, the $19^{\text {th }}$ century can comfortably called the heyday of the historical constitution of Hungary. Starting with a period of latent reform work on what was called linguistic neologism (nyelvújitás), it continued with an intense period of a two decadelong constitutional reform movement, when the political class got widened up, by members of the lower classes of the nobility and non-noble intellectuals (called literati by Péter), which led to the legal revolution of the April laws of 1848 , followed by a War of Independence, which was lost, but regained in the form of the 1867 Settlement, which created the new state-formation of the Austro-Hungarian dual monarchy.

Péter, in one of his seminal papers, chose two simple aspects to describe the specificity of Hungarian political thought and action in the $19^{\text {th }}$ century, the struggles around language and the idea of the "ancient constitution" (Péter, 2012b). Analysing an article by the editor of one of the earliest political journals, Hazai Tudósítások, by its editor, István Kultsár, entitled “Who are Hungarians?” comes to the conclusion that 
"the term magyar nemzet (Hungarian nation, FH) may not have acquired its modern senses before the language movement of the literati fused with the political reform programme that emerged within the nobility to establish a civil society based on the principle of legal equality" (Péter, 2012b, p.188). The linguistic reforms proved more successful than the constitutional struggle. It started in 1792 with article VII, which "introduced Hungarian as an ordinary subject in grammar school" and led through "Article III of 1836," which "declared the Hungarian text of the laws (rather than the Latin) to be authentic," to 1844 "when Law II made Hungarian the sole language in which laws were enacted” (Péter, 2012b, p.189).

With the constitutional reform the development was not quite so linear. For reformers (aristocrats, nobles, and non-nobles) had to fight on two fronts: they had to defend the ancient constitution (in other words the liberties and privileges of the nobles - representing by now the whole nation ${ }^{12}$ ) against the centralising trespasses of the court and its government), and fight to break down those very privileges in order to let the people enter behind "the ramparts of the constitution" (az alkotmány sáncai). ${ }^{13}$ While the first front was obvious by then, the second front was one in which the nobles had to turn against their own interests. The solution to this political riddle was the strategy of the extension of rights (jogkiterjesztés) instead of a termination of privileges, which would have perhaps a more radical (more democratic) internal effect, but should have annulled the ancient constitution and should have authorized Vienna to provide a new constitutional framework or even a non-constitutional form of government. After the bloodless revolution of 1848, the April Laws "broke the back of the old order based on hereditary right and introduced independent, representative and responsible government" (Péter, 2012b, p.195). Although the new regime was forced into a hopeless war of independence where the Hungarian civic militia was crushed down with the help of the overwhelming power of the Russian Tsar's army, 1848 "set a standard for Hungarian politics that outlasted even the Monarchy." In the 1867 Settlement, the lost constitution was "repossessed' and a new balance was created between the Crown and the nation" (Péter, 2012b, 195). However, the story is once again unfinished: "Although the drawbridge of the constitution was lowered in 1848 and in 1867, the gates were not flung wide open." (Péter, 2012b, p.195).

Even more importantly, a serious distortion was introduced during the $19^{\text {th }}$ century: a constitutional doctrine that worked as an ideology, which led astray the constitutional development of the country. This is the famous doctrine of the Holy Crown, the idea that the constitutional history of the kingdom is unparalleled, as it was based on an acclaimed thousand years of history, and represented a specific vision of politics. In a long and detailed investigation, Péter traces back the birth of

12 "When Kossuth makes the claim that Hungary 'belongs to the Hungarians' and refers to 'our constitution' the referent is no longer the nobility but the nation led by the nobility" (Péter, 2012b, p.195). 13 The expression, used by Pál Felsőbüki Nagy in 1827, became a famous adage of the period. 
the doctrine to the oppositional figure of Count Albert Apponyi, a "magnetic personality and oratorical brilliance," who in the 1889 Great Defence Debate provided the political context of the Holy Crown doctrine, a joint production of the exceptionally talented and influential theorist Győző Concha, the excellent Vienna educated legal historian and legal theorist Imre Hajnik, and Ákos Timon, another representative of the turn-of-the-century Hungarian style, but Germanic (dogmatic) historical school of law, all the three of them having chairs at Budapest University. The terminological shift that prepared the way for the doctrine was that ország (country) was replaced by the more modern notion of állam (state). While earlier there was "a dualist division between king and ország, according to the new doctrine " "the subject of sovereignty was the Holy Crown' which comprised the crowned king and, 'in former times through ennoblement, today through the franchise', the members of the crown." In other words the modern (German Staatsrecht) concept of the state was always there in the Hungarian historical constitution, only called the Holy Crown, which led to the conclusion that "neither the Monarch nor the People but the State itself ought to be regarded as the subject of state sovereignty" (Péter, 2012f, p.225). This innovation served the function to widen up the space for the Hungarian government once again on two fronts: against the Monarch, who tended to rely on his ancient ius reservata (the reserved right of the sovereign), and against the individual rights of citizens and the institutions of civil society. This distortion of the original balance of king and parliament was most obviously expressed in the autocratic principle of the law, which Péter regarded as a common feature of the Habsburg Monarchy and imperial Germany, and he found it as the major obstacle to democratic (rule of law) developments in Hungary, which brought with it in Hungary a fatal obstruction of the growth of civil rights (unlike in the other half of the Dualist Monarchy) (Péter, 2012g; Cieger, 2015). His fulminatory view of the doctrine is due to the fact that he regarded it as "constitutional radicalism" which "resulted in the introduction of an instability in the political life of the Hungarian part of the Monarchy” (Péter, 2012f, p.224).

\subsection{Anachronistic Afterlife, Death and Revival (?) of the Historical}

\section{Constitution: The Twentieth Century}

The instability led to government crises in the early $20^{\text {th }}$ century, but the regime could survive until the outbreak of the First World War. However, as Hungary lost the World War, the the Allies revenged with a fatal blow: the kingdom of Hungary lost the majority of its historic territory and population. This moment should have been seen as the end of its constitutional tradition and the occasion to redraw its constitution (Romsics, 1999, p.81). Because the historical constitution, as noted, was part of an ancient, customary kind of constitutional culture, it managed to survive even this political catastrophe. The new political system that came into power after long 
months of authoritarian regimes in power (first the red revolution of the Hungarian Republic of Councils, later what is called the white terror of a radical right counterrevolutionary regime), and which was stabilised around the personal charisma of the would-be regent, Miklós Horthy, an earlier admiral of the Dual Monarchy, kept the state's form of kingdom, except that it did not allow the Habsburg dynasty to take the throne. Horthy himself served as an uncrowned king at the top of the political regime that, as many other interwar regimes in the region, had an authoritarian character (Turbucz, 2014). While Hitler's takeover was due to the fiasco of the Weimar constitution of Germany, the Kingdom of Hungary did not work because of its anachronistic nature. This anachronism is captured by the term phrased by Gyula Szekfü, who called the contemporary Hungarian society a "neo-Baroque society" (Szekfü, 1920/1938). The official ideology of this state was a kind of revisionism or irredentism, which radically questioned the justice of the Trianon treaty and expressed the hope of Hungarians that the lost territories and the lost native population can be regained - a major cause of Hungary joining Germany at the outbreak of the Second World War. Keeping the constitution was also a political manifesto, which sent the message: Hungarians do not accept the external constraints of the stronger, and keep to their own constitutional tradition.

In reality, however, the historical constitution lost its credibility, as after the collapse of the dual monarchy there was in fact no need to keep the "közjogi kérdés" (the question of public law) on the agenda, except for territorial demands, which, however, were largely determined by the foreign political constellation, and could not be hoped to bring any positive results by simple techniques of elaborate legal disputes. The historical constitution, however, had two further aims which it could very well serve: first, to hinder a democratic turn by the introduction of universal suffrage which was on the agenda in more and more European countries in those years, and with it to postpone the defence of individual rights. The anti-democratic tendencies could be recognised in the party system as well, or in the workings of the Parliament, where real competition could be avoided. And second, to hinder social mobility, by ensuring that the historical liberties and privileges of the nobility and the aristocracy (including the system of large landed estates) were defended, and this way a wide spectrum of society could not in fact avoid experiencing extreme poverty. Beside those of the traditional estates (the aristocracy, the nobility and the Church) the state served the interest of the so called Christian-national middle classes - as opposed to the large groups of agrarian paupers, and those city-dwellers who were of non-Hungarian origins, including the Jews, against whom they introduced a whole series of legislation, and half a million of whom they left preys of the anti-Semitic Nazi regime of the German Reich after the outbreak of the Second World War. ${ }^{14}$ That this sort of

14 For a contemporary critique of the anachronistic social structure and the previaling antisemitism of the interwar period and during the Second World War, see Bibó, 1982-1984; Bibó, 1982-1984b. 
scapegoat mechanism could be so easily operated against a group of citizens is a sure sign that at that time the historical constitution was not able to serve the function which we expect from a constitution, meaning a defence of individuals against the monopoly of state power. The illusion of gaining back earlier territories blinded the political elite, including the regent, and made the country the prey of Hitler, who used the Hungarian political class for his own purposes and then occupied the country to make sure of their loyalty. After the suicide of Prime Minister Pál Teleki, in 1941 there was no real leadership in the government, which resulted first in the Nazi takeover in 1944, and then in the total surrender of the country before the 1945 Soviet communist invasion.

There is no wonder that the newly consolidated communist regime wanted to get rid of the historical constitution. Following the Soviet example of the Stalinist constitution, a new statutory constitution was introduced in 1949, ending the long story of the historical constitution, and starting a new era of quasi-constitutionalism under a totalitarian kind of rule. This was a written constitution, which ascertained the leading role of the communist party, and this way operated an oppressive party-state system, along the teaching of the official Marxist-Leninist doctrine. Although communist rule was interrupted by the revisionist revolution of 1956, led by the earlier communist leader, Imre Nagy, János Kádár, the new first secretary backed by the Soviets once again consolidated a slightly milder system, and ensured its survival and his personal leadership in it until 1989. There is no need to dwell long on this period, as it was a shop-window kind of constitutionalism, which did all that it could to encumber the external recognition of its real nature, which remained totalitarian down to the bottom.

The transition of 1989 prepared the way for a new constitutional regime after a fair general election in 1990. The election laws were collated among the participants of the National Roundtable Agreements, and this way it ensured the transition to a genuinely democratic system. Although a lot of political commentators had serious worries about the new political settlement, which were originally meant to be only transitory, no government majority could again put on the agenda constitution drawing. However, a two-third majority enabled Fidesz to draw a new constitution once again, claiming that the 1990 one was based on the earlier, illegitimate 1949 one. The new Fundamental Law of Fidesz, which was itself illegitimate according to its critics, because the parliamentary opposition had not participated in the drawing of it, and the population did not formally accept it, made an effort to revitalise the historical constitution. In its ideological orientation, called the National Avowal, it provides the following historical judgement:

We do not recognise the suspension of our historical constitution due to foreign occupations. ... We do not recognise the communist constitution of 1949 , since it was the basis for tyrannical rule; therefore we proclaim it to be invalid. ... We date the restoration of our country's selfdetermination, lost on the nineteenth day of March 1944, from the second day of May 1990, when 
the first freely elected organ of popular representation was formed (The Fundamental Law of Hungary, 2011, National Avowal).

There are serious problems of legal technique with a constitutional text that claims to be rooted in the earlier constitution, but which calls the former constitutional regime annulled, because of the fact that it served a totalitarian regime. But a more significant problem is that the new Fundamental Law is open to charges of illegitimacy because of the opposition being left out from the procedures of drawing it. As a result it is not yet certain whether it can survive the next election - although it has already survived one, but that election was won by Fidesz, the same party that has drawn the Fundamental Law. Consequently, its heroic effort to turn back time, and to reintroduce what is called the achievements of the "historical constitution" is still rather doubtful. ${ }^{15}$

The success of such an innovative step depends on the reaction of the constitutional court, which is accused of being full of Fidesz-friendly constitutional judges, but which wants to preserve its own professional reputation based on the decisions of the first period of its history, when it was led by its first president, László Sólyom, whose heritage of the constitutional culture of the post 1990 Hungary is still relevant for the present constitutional court. This tension between the spirit of the new Fundamental Law and the constitutional culture of the constitutional court cannot be easily resolved. Some of the norms of the fundamental law try to reshuffle the sense of the constitution, like in article $\mathrm{R}$ where it is claimed that "The provisions of the Fundamental Law shall be interpreted in accordance with their purposes, the National Avowal contained therein and the achievements of our historical constitution" (Fundamental Law, 2011). However, so far there is no agreement how to identify the real "achievements" of the historical constitution in the above quoted text. The constitutional court, of course, has all the powers to make sense of this imprecise term; but apparently it is not too keen to do so, and constitutional or legal historical scholarship has not achieved too much so far, either (Hörcher, 2015).

15 See the text of the National Avowal: "We honour the achievements of our historical constitution and we honour the Holy Crown, which embodies the constitutional continuity of Hungary's statehood and the unity of the nation" (The Fundamental Law of Hungary, 2011). I think that the close conceptual link drawn here between the historical constitution and the Holy Crown makes a potential interpretational breakthrough rather difficult, because of the strong reactions amongst lawyers against a return to the veneration of the Crown. 


\subsection{The Achievements and the Failures of the Historical}

\section{Constitution}

In a relatively early writing, published in 1994, the later constitutional court judge, and even later president of the constitutional court, Péter Paczolay gave his thoughts on the relation between the historical constitution and conservative legal thought (Paczolay, 1994). Paczolay, who was a legal theorist and political scientist before he became a judge, claimed that:

The historical constitution characteristically and necessarily interlocks with the conservative philosophy of state and law: with the principle of continuity and gradual development. The changes of Hungarian public law had a conserving nature, beside its natural progression. The stability behind the reforms, the adaptation of the ancient principles to the new circumstances, about which the Hungarian public law theorists tended to write, echo the ideas of Burke (Paczolay, 1994, p.33).

In his historical reconstruction Paczolay points to two historical events that broke the continuity of the traditional historical constitution: these were in 1919 the establishment of the Soviet type Republic of Councils and in 1949 the Communist written constitution of Rákosi. While neither of them was legitimate, the latter, written (kartâlis) constitution is claimed to have actually terminated the historical constitution. In Paczolay's view even if Hungary wanted to, it could not turn back to the historical constitution, as it is by now unfortunately discredited. Using a traditional metaphor he claims that the constitution's building was totally destroyed by the storms of the $20^{\text {th }}$ century. It cannot be brought back, and no new historical constitution can be created, it is conceptually impossible. It is inevitable, therefore, he claims that Hungarians will live under the jurisdiction of a charta-like constitution, which however has to preserve from the ancient Hungarian constitution whatever is possible to be preserved. He thinks that the 1989 constitutional process was not the "most fortunate" but he takes it even so legitimate, and finds in it in some aspects a return to the pre-1949 one. The most important point where he thinks that the customary nature of the historical constitution can be reintroduced is the judge-directed development of law (bírói jogfejlesztés). While this possibility was excluded from the socialist concept of the law (which had as its ideal the Kelsenian type of legal positivism), after 1989 there is a chance to return to the Hungarian legal traditions in this respect through the Kúria's role in the development of the law. Through the legal interpretation of the judge the lacunas of the law can be filled up, which was quite naturally achieved in the historical constitution due to the customary nature of the law and precedents. The constitutional interpretation of the law by the judge is a new development which helps to inject a customary-historical element into the constitutional life even if the constitution itself is written. 
Paczolay's ideas were realised at the same time by the activist self-perception and practice of the first president of the Hungarian constitutional court, László Sólyom. His ideal, the so-called "invisible constitution," was the custom of the court to build around the written norms of the constitution a context of interpretations, in their judgements, which, in order to dig out the constitutional principles behind the text of the particular norm, sometimes went recognisably beyond the original intention of the lawgiver. Interestingly, however, it was exactly the conservative lawyers and politicians who criticised the practice, claiming that the practice of the constitutional court stretched much beyond what was originally intended for them in the model of the separation of powers. Here, of course, a similar argument appeared as the one used in the case of the United States Supreme Court, where conservative judges try to adhere to the original meaning of the text as the norm, and claim that activism in interpretation can dangerously miss the original intention of the lawmaker or simply the original meaning of the text of the law (Pilon, 2001). Sólyom's original intention was to try to build a coherent system of the interpretations of particular debated issues in the light of the text of the constitution, and this way to fill in the gaps of the constitutional text and logic and to defend the constitution from any spontaneous constitution drawing intentions of the parliament for pragmatic political purposes. ${ }^{16}$ In a later writing Sólyom made it clear that he saw the point of the criticism, but thought that it was based on a misinterpretation of his metaphor, when it was understood as referring to "activism and countermajoritarian aspirations of the Court" (Sólyom, 2000, p.41).

László Sólyom's understanding of the historical constitution became once again relevant in the context of the debate about the new Fundamental Law, drawn by the two-thirds Fidesz majority in 2010-2011. Sólyom provided a serious critique of the new venture that he thought might endanger the whole edifice of the invisible constitution. When he realised the importance attached to the notion of historical constitution by the drafters of the Fundamental Law, he innovatively rephrased his former concept, claiming that in fact the real meaning of the historical constitution was exactly the invisible constitution built around the text of the written constitution by the court, in the way implied by Paczolay's earlier essay. In other words he suggested that if there is a constitutional demand to return to the historical constitution, one should look at the court's jurisdiction during its 20 years history: "the Fundamental Law states that its provisions shall be interpreted in accordance with the achievements of the

16 According to Sólyom: "The Constitutional Court must continue its effort to explain the theoretical bases of the Constitution and of the rights included in it and to form a coherent system with its decisions, which as an 'invisible Constitution' provides for a reliable standard of constitutionality beyond the Constitution, which nowadays is often amended out of current political interests; therefore this coherent system will probably not conflict with the new Constitution to be established or with future Constitutions" (Decision 23/1990, 2000, p.126). 
historical constitution - but the achievements which can be used today evolved after 1990. The new constitution of that period incorporated also the achievements of 1848 and 1946. And the constitutional court, since then kept writing a historical constitution, if you want” (Sólyom, 2011).

But there is a further step in Sólyom's innovative interpretation of the historical constitution. He claims that in fact constitutional life consists of written or unwritten norms, and a certain form of constitutional culture attached to it. "A new constitution cannot repeal the legal culture, into which it is born. These two mutually form each other in the long run... Constitutional culture is continuous, it takes shape slowly so far it is comparable to the historical constitution. A written constitution can also follow the radical transformation of social demands and the ever new face of constitutional culture" (Sólyom, 2011). Obviously his hope is that in spite of the constituent power's intention, the new Fundamental Law - the text of which is to a large extent simply taken over from the 1989-1990 constitution - cannot cut itself away from the constitutional reality which consists of the written constitutional norms and of the constitutional culture into which these norms are born.

It is too early as yet to judge whether Sólyom's hope will be fulfilled. But it is sure that his understanding of the historical constitution is heavily bottlenecked. Neither Paczolay nor Sólyom could accept the revival of the idea of the historical constitution cherished by Babits in our motto. They absolutely doubt that the historical constitution could survive the four decades of the written Soviet-type constitution, which they both claim to be illegitimate.

The present paper is based on a different assumption. According to this assumption, constitutional reality is a social construction, which means that it can be deliberately changed - perhaps not too abruptly, but slowly and gradually. If there is a consensus among constitutional lawyers and other legal practitioners, politicians, and the opinion mongers that the historical constitution should be regarded as still valid, it is only a question of time, interpretational innovation, and invested energy to draw the conclusions of this consensus in the long run. As already the title of the new constitution (i.e., Fundamental Law) suggests, the intention behind its drawing was that it will serve as a key text in the process of reconquest of the historical constitution, one which in the same time takes responsibility also for its renaissance.

Certainly there posit serious obstacles that hinder the realisation of this intention. Most importantly one should be careful not to get anachronistic or simply foolish by taking some parts of the historical constitution verbatim. After all, who wants to revive feudal social conditions, the ius reservata of the kings, or anti-semitic legislation? Only the carefully chosen key elements should be saved for the benefit of future legal argumentation, and a special care should be paid to neutralize the negative effects of the potential survival of its failures. Undoubtedly a more thoroughgoing analysis than what is possible in this paper is required to address this pressing issue. This paper can only argue that a written Fundamental Law does not per definitionem 
exclude the possibility of the legal presumption that the historical constitution is still alive, the only problem being that we cannot as yet define properly the content of it.

But one further step may be taken here: to formulate a proposal about the direction towards which the new interpretation of the reborn historical constitution could be switched.

\subsection{How to Reinterpret the Tradition of the Historical}

\section{Constitution?}

One of the key problems of the 1989/1990 Hungarian constitution was that ordinary citizens could hardly identify with the view of politics that it presented. Instead, the general public regarded the document as the constitution of law professors, legal experts and lobby groups primarily interested in individual rights. This was partly due to the fact that its text and the court's interpretation tried to join the Western constitutional discourse, without taking due care about the home ground. Therefore, a lot of the members of the political elite could not easily catch up with it. Consequently it quicly lost those otherwise interested in politics but not interested in present-day constitutional theoretical nuances or human rights lobbying.

But what is the guarantee that the historical constitution, a theme offered by the new, 2012 Fundamental Law, would look more sexy in the eyes of its present audience? A strong conviction tells us that the future of the Fundamental Law is in the hands of professional constitutional lawyers and the courts. Theoretically oriented lawyers' interpretation of it should lend it a cogency, and their job it has been offer a vision of the rebirth of the historical constitution which is compelling to the next few generations. In other words, the interpretation of the past should be tuned to the expected tastes of the future. But, certainly, traditional Kelsenist lawyers are naturally not in favour of it. And the constitutional lawyers of the last twenty years, mostly from a younger generation, who were brought up on the vision of the constitution transmitted by the constitutional court, or directly picked up at fashionable or second-rate European or American universities, in fact reside on the other side of the debate. And Hungarian conservatism, which has overthrown the earlier constitution, is not yet sufficiently intellectually robust to take up the challenge to make sense of the references in the Fundamental Law to the achievements of the historical constitution.

To conclude, I respectfully offer my own, non-legal suggestions how to use the historical constitution today. My starting point is the social constructivist assertion that if there are good reasons why to refer to the historical constitution as a living document, it could be done. Next, I admit that, as Paczolay already saw, the historical constitution was destroyed in the $20^{\text {th }}$ century. But I would add, presumably in agreement with such diverse authors as Szekfü and Bibó, that since the end of the dualist period (late $19^{\text {th }}$ early $20^{\text {th }}$ centuries) the Hungarian constitutional mindset wandered 
seriously astray. And third, let me suggest that historical deadlocks can offer lessons from which important conclusions or lessons might be drawn.

Thus, here are a few of the lessons of the earlier discourse of the historical constitution which I take to be relevant even today constitutionally. First, obviously, one should reconsider one of the most important trait of the historical constitution, its dualist nature. As shown, the doctrine of the Holy Crown was quite a late arrival, but the cast itself has a long history, where the king and the country (ország) obviously represent the two scales of the balance. The lessons from this old constitutional division include the one István Szijártó has drawn: that there is a republican element in the way the ország functioned in the $18^{\text {th }}$ century. Yet it is also remarkable that due to this dualist structure, the diet was forced to cooperate with the king and to look for viable compromises in these negotiations. In other words, at least until the second half of the $18^{\text {th }}$ century, the dualist structure brought with it less an agonistic struggle and more a constitutional culture of compromises. It is only since then that a sharper, zero-sum game has been started in the political arena.

Second, another early experience was the confessional division of the constitutional life of the kingdom. It was partly due to the fact that the Habsburg dynasty was emphatically Catholic - although Szijártó also mentions that there were occasions when their political interests could override their confessional identity. The early success of the reformation, mostly in the northwestern parts of the country, is relevant because it could contribute to the schizophrenic nature of the population, inhabitants of the three parts spoke different political languages, and the theological controversies explain the early politically motivated cultural wars which were occasioned by the confessional struggles. It also explained the persistent existence of rival historiographies - the loyal Catholic ones talked about loyalty, while the protestant ones cried in a non-compromising manner liberty.

Third, if we turn to the heyday of constitutionalism, the long $19^{\text {th }}$ century, a key question concerned the fate of the county or local assembly, which had a power to take over a lot of the burdens of political life, but this way frustrated the state's central authorities. This conflict is also easy to explain in the language of despotism (Viennese central authority) versus liberty (local communities), but already the centralists, a group of well educated, politically active intellectuals, from the 1940s were keen to call attention to the general misfortunes caused by geographic and institutional fragmentation. On the other hand, local communities could accumulate practical knowledge about political necessities, which again lead to a political (or constitutional) culture based on political participation and the demand of autonomy and self-government.

Fourth, a further question is the returning historiographical commonplace that Hungary arrived late in liberating not only its serfs, becoming the country of three million beggars, but also in offering constitutional rights to its bourgeois middle classes, in particular the city-dwelling burghers. The issue called the question of cities (városi kérdés) became quite hot during the Reform era, but was not solved in 
a proper manner even in the April Laws. And although the period between the Settlement with Austria and the First World War saw an unprecedented urban growth, Hungary remained comparatively underdeveloped, as far as urban centres, industry and commerce is concerned in the last decades of its being a kingdom. And even more importantly, social mobility turned out to be even slower and severely limited, which could have been one of the key indirect reasons behind the anti-Semitic feelings, legislation and the state's betrayal of its Jewish citizens during the time of the Holocaust.

Fifth, and finally, a further dimension of the historical constitutional experience of Hungarians might be relevant even today: that the kingdom of Hungary was constitutionally part of a larger whole, called Habsburg empire. Although the political elite since the time of Werböczy tried to play on the national monarch's issue, and regarded the dualistic arrangement only as a concession, when they accepted the system, they also participated in stabilising it. In a comparison of the Hungarian kingdom and Austria, in or after 1848, the Hungarian part seems to be much more liberal than the other side of the political spectrum, as it had its own well defined and practiced constitutional arrangement, while Vienna, which was on other hand more urbane and unchecked, followed in a much slower tempo the fate of Western capitals, by checking the monarch's direct power. It would be nice to see how the general public in Hungary relates to these issues nowadays, when the imperial logic of Europe towards the small countries is once again easily felt and seen, for a population which learned from the Russian invaders that autonomy matters.

\section{Bibliography}

\section{Legal Sources}

Werbőczy, S. (2005), The Laws of the Medieval Kingdom of Hungary, Volume 5. The Customary Law of the Renowned Kingdom of Hungary: A Work in Three Parts Rendered by Stephen Werboczy (The “Tripartitum"), (Eds.), János M. Bak, Péter Banyó and Martyn Rady, Charles Schlacks, Jr. Idyllwild CA Department of Medieval Studies, Central European University, Budapest.

The Fundamental Law of Hungary (2011), http://www.kormany.hu/download/e/02/00000/ The\%20New\%20Fundamental\%20Law\%20of\%20Hungary.pdf.

Decision 23/1990 (2000), On Capital Punishment, Concurring opinion of László Sólyom, in Sólyom, L. (2000): Introduction to the Decisions of the Constitutional Court of the Republic of Hungary, In L. Sólyom and G. Brunner: Constitutional Judiciary in a New Democracy. The Hungarian Constitutional Court (118-138), Ann Arbor, The University of Michigan Press.

\section{Books and articles}

Ablonczy, B. (2005). Teleki Pál. Budapest: Osiris Kiadó.

Babits, M. (1939). A magyar jellemről. In Gy. Szekfü (Ed.), Mi a magyar? Budapest: Magyar Szemle Társaság.

Bahlcke, J. (2005). „Libertas”-Vorstellungen in der ständischen Gesellshaft Polens, Böhmens und Ungarns. In Political Culture in Central Europe (10-20th Century), vol. I: Middle Ages and Early 
Modern Era, (Eds.), Halina Mankowska - Jaroslav Pánek. Prague: Institute of History, Academy of Sciences of the Czech Republic; Warsaw: Institute of History, Polish Academy of Sciences.

Berger, P. \& Luckmann, Th. (1966). The Social Construction of Reality. A Treatise in the Sociology of Knowledge. Garden City, N. Y.: Doubleday.

Bibó, I. (1982-1984). A magyar társadalomfejlődés és az 1945. évi változás értelme. In I. Bibó, I.: Összegyújtött munkái 1-4., vol. 2. (Eds.), I. Kemény and M. Sárközi, Bern: EPMSZ.

Bibó, I. (1982-1984b). Zsidókérdés Magyarországon 1944 után. In I. Bibó: Összegyűjtött munkái 1-4., vol. 2. (Eds.), I. Kemény and M. Sárközi, Bern: EPMSZ.

Cieger, A. (2015). Állam és állampolgár viszonya a dualizmus kori Magyarországon. Péter László nézetei az autokratikus jogelv müködéséről. In: Közjogi Szemle, VIII., September, 30-34.

Concha, Gy (1885/2005). A kilenczvenes évek reformeszményei és előzményeik, Máriabesenyő Gödöllő: Attraktor.

Czoch, G. (2007). The question of Urban Citizens' National Identity in Mid-Nineteenth Century Hungary. East Central Europe/L’Europe du Centre-Est: Eine wissenschaftliche Zeitschrift. Vol. 33. 2006.

Hantos, E. (1904). The Magna Carta of the English and of the Hungarian Constitution: A Comparative View of the Law and Institutions of the Early Middle Ages. London: Kegan Paul, Trench, Trubner and $\mathrm{Co}$.

Hörcher, F. (2016). Enlightened Reform or National Reform? The Continuity Debate in the Hungarian Reform Era (1790 - 1848) and the Example of the Two Széchenyis. Hungarian Historical Review, 1.

Hörcher, F. (2015). The National Avowal, An Interpretation of the Preamble, from the Perspective of the History of Political Thought. In András Zs Varga, András Patyi, Balázs Schanda (Eds) The Basic (Fundamental) Law of Hungary: A Commentary of the New Hungarian Constitution. Dublin: Clarus Press.

Marczali, H. (1896). Magyarország története az Árpádok korában, A rendi alkotmány kezdetei. Budapest: Athaeneum.

Melhár, Gy. (1906). Somogy vármegye a rendi országgyúléseken,Veszprém: Egyházmegyei Könyvnyomda.

Miskolczy, A. (2005). Egy történészvita anatómiája. 1790-1830/1848: folytonosság vagy megszakítottság? (avagy „Mit üzent Kossuth Lajos?”), Aetas (2005), 1-2.

Montesquieu, C. L. de S. (1777). Complete Works, vol. 1., The Spirit of Laws [1748], London: T. Evans.

Paczolay, P. (1994). A történeti alkotmány és a konzervatív jogi gondolkodás. In L. Tókéczki (Ed.), Magyar konzervativizmus. Hagyomány és jelenkor. Budapest: Batthyány Lajos Alapítvány.

Pilon, R. (2001). Lawless Judging: Refocusing the Issue for Conservatives, 2 GEO. J.L. and PUB. POL'Y. 5.

Péter, L. (2005). The Irrepressible Authority of the Tripartitum. In (Werboczy, 2005).

Péter, L. (2012). Montesquieu's Paradox on Freedom and Hungary's Constitutions, 1790-1990. In L. Péter, Hungary's Long Nineteenth Century. Constitutional and Democratic Traditions in a European Perspective. Collected essays, M. Lojkó (Ed.). Leiden-Boston: Brill.

Péter, L. (2012b). Language, the Constitution, and the Past in Hungarian Nationalism. In L. Péter, Hungary's Long Nineteenth Century. Constitutional and Democratic Traditions in a European Perspective. Collected essays, M. Lojkó (Ed.). Leiden-Boston: Brill.

Péter, L. (2012c). The Irrepressible Authority of Werbőczy's Tripartitum. In L. Péter, Hungary's Long Nineteenth Century. Constitutional and Democratic Traditions in a European Perspective. Collected essays, M. Lojkó (Ed.). Leiden-Boston: Brill.

Péter, L. (2012d). The Holy Crown of Hungary, Visible and Invisible. In L. Péter, Hungary’s Long Nineteenth Century. Constitutional and Democratic Traditions in a European Perspective. Collected essays, M. Lojkó (Ed.), (15-112) Leiden-Boston: Brill. 
Péter, L. (2012e). Ius Resistendy in Hungary. In L. Péter, Hungary’s Long Nineteenth Century. Constitutional and Democratic Traditions in a European Perspective. Collected essays, M. Lojkó (Ed.). Leiden-Boston: Brill.

Péter, L. (2012f). The Dualist Character of the 1867 Hungarian Settlement. In L. Péter, Hungary's Long Nineteenth Century. Constitutional and Democratic Traditions in a European Perspective. Collected essays, M. Lojkó (Ed.). Leiden-Boston: Brill

Péter, L. (2012g). The Autocratic Principle of the Law and Civil Rights in Nineteenth-Century Hungary. In L. Péter, Hungary's Long Nineteenth Century. Constitutional and Democratic Traditions in a European Perspective. Collected essays, M. Lojkó (Ed.). Leiden-Boston: Brill.

Pocock, J. G. A. (1987). The Ancient Constitution and the Feudal Law. A Study of English Historical Thought in the Seventeenth Century. A Reissue with a Retrospect. Cambridge: Cambridge University Press.

Rady, M. (2005). Stephen Werbőczy and his Tripartitum, in Werboczy (2005).

Rady, M. (2014). Hungary and the Golden Bull of 1222. Banatica, 24 - II.

Rady, M. (2015). Customary Law in Hungary. Courts, Texts, and the Tripartitum. Oxford: Oxford University Press.

Romsics, I. (1999). Hungary in the Twentieth Century. Budapest: Corvina Books.

Sólyom, L. (2000). Introduction to the Decisions of the Constitutional Court of the Republic of Hungary. In L. Sólyom and G. Brunner (Eds.), Constitutional Judiciary in a New Democracy. The Hungarian Constitutional Court. Ann Arbor: The University of Michigan Press.

Sólyom, L. (2011). Alkotmány és alkotmányos kultúra Magyarországon, paper presented on 29. November 2011. at the National Conference of History Teachers, http://www.tte.hu/ toertenelemtanitas/toertenelemtanarok-orszagos-konferenciaja/7356-solyom-laszloalkotmany-es-alkotmanyos-kultura-magyarorszagon.

Sólyom, L. (2015). The rise and decline of constitutional culture in Hungary. In A.von Bogdandy and P. Sonnevend (Eds.), Constitutional Crisis in the European Constitutional Area. Theory, Law, and Politics in Hungary and Romania. Oxford and Portland, Oregon: C.H.Beck - Hart - Nomos.

Szekfü, Gy (1920/1938). Három Nemzedék és ami utána következik. Budapest: Királyi Magyar Egyetemi Nyomda.

Szijártó, M. I. (2005). A diéta - A magyar rendek és az országgyúlés 1708-1792. Budapest: Osiris.

Szijártó, M. I. (2012). A „konfesszionális rendiségtől” az „alkotmányos rendiségig”. Lehetőségek és feladatok a 18. századi magyar rendiség kutatásában, Történelmi

Szemle, 54., 1.

Szijártó, M. I. (2015). Péter László, a rendi alkotmányosság és a kései rendiség historiográfiája, Közjogi Szemle, VIII., September.

Turbucz, D. (2014). Horthy Miklós, Budapest: Napvilág Kiadó.

Varga, B. (2004). The Term Libertas in 17-18th century Hungary. Studia Caroliensia, 3-4.

Varga, B. (2006). Szempontok a Bocskai-felkelés ideológiájának európai kontextusához, Studia Caroliensia, 1.

Zászkaliczky, M. (2012). The language of liberty in early modern Hungarian political debate. In Q. Skinner, M. van Gelderen (Eds.), Freedom and the Construction of Europe: Volume 1, Religious Freedom and Civil Liberty. Cambridge: Cambridge University Press.

Zászkaliczky, M. (2012b). Protestant Political Theology and Corporate Constitutionalism in the 16-17th c. Hungary. (PhD Thesis, CEU).

Zászkaliczky, M. (2015). Eszmetörténeti szempontok a történeti alkotmányosság közép- és kora újkori magyarországi történetéhez. Közjogi Szemle, VIII., Szeptember.

Zsoldos, A. (2011). II. András Aranybullája, Történelmi Szemle, 53. 


\section{Arkady Rzegocki ${ }^{1}$}

\section{Polish Constitutional Traditions}

Poland has one of the longest traditions of parliamentarism and constitutionalism in Europe. It reaches as far back as the fourteenth century, and a well-formed constitutional system dates to the beginning of the sixteenth century. Long and uninterrupted constitutional and parliamentary tradition is one of the reasons why the Polish case has to find its chapter in a study on the development of constitutionalism.

While France sets example as a country where estate monarchy evolved into absolute monarchy and where royal powers were eventually put under control and limited, Poland is an exemplary model of a country where medieval estate monarchy was decentralized with the growing participation of citizens and civic representative institutions. In a word, the Polish system of governance evolved first into constitutional monarchy and then into parliamentary monarchy bypassing the absolutist stage.

Most overviews of the Polish constitutionalism start with the Act of Government of 3 May 1791 ("1791 Polish Constitution"). It was a milestone in the rich and arduous history of the Polish constitutionalism, however it was preceded by other legal acts that formed a ground upon which constitutional state developed. The 1791 Polish Constitution, or the so-called 3rd of May Constitution, was the first act of governance in Europe to introduce reforms of political system. Its only predecessor in Europe was the 1755 constitution of Corsica. What is remarkable about the 1791 Polish Constitution was the fact that it was a product of evolution rather than revolution as it introduced reforms into constitutional and parliamentary system that had already been in place for centuries. Historians point to the fact that, contrary to the then current political trend to limit central organs of government and royal power and to give more power to the citizens, the 1791 Polish Constitution went in a different direction, by instituting hereditary monarchy, that is, by cancelling elective monarchy, by limiting elective rights of the nobility, and by cancelling the principle of consensus in the parliament (LT liberum veto). The reasons for a more guarded approach to the protection of citizens' rights and freedoms in Poland were the need to strengthen the central government in otherwise federalist and decentralized state in the face of the danger from the neighbouring absolutist states.

Poland may be considered a constitutional monarchy from the sixteenth century onwards. Although it did not have a single act setting out the roles of the most important organs of state power, it nevertheless had a number of institutional regulations, such as, for example the lex et rex rule, that is, the rule of the superiority of the law, which applied in all of the Commonwealth of Poland-Lithuania. The legislature of the

1 The Jagiellonian University in Kraków. 
early $16^{\text {th }}$ century Jagiellonian state and the Polish-Lithuanian Commonwealth should be recognized as the forerunner of Polish constitutionalism. In the same vein, the English constitutionalism draws its fame from a long-standing tradition despite the fact that it has no single constitutional document and its "unwritten" constitution is embodied in a variety of documents and sources. The sum of the written documents and regulations that applied in the Jagiellonian state allows us to conclude that the Jagiellonian monarchy was a constitutional monarchy in the beginning of the sixteenth century, that is, 183 years before the Glorious Revolution in England.

Despite historical evidence testifying to the remarkable constitutional tradition in the Jagiellonian state, it is England that has been deemed the first constitutional monarchy, emerging as a result of the Glorious Revolution and change of dynasty in 1688-1689. Thus, England has been called "the mother country of parliaments" and the Westminster model of parliamentarism has been adopted in many countries of the former empire. British-style parliamentarism was successfully implemented in Canada, Australia and New Zealand, and therefore it comes as no surprise that England and Great Britain are the first associations with parliamentarism, constitutional governance, and democracy across the world. There is no doubt that the fame of the English parliamentarism is well-earned and the influence of English legal and constitutional model has been beneficial to many countries.

That said, the beginnings of the English constitutionalism and parliamentarism were difficult and problematic. Like most European countries in the sixteenth and seventeenth century, England was heading towards absolutism as subsequent monarchs gradually limited the role of the parliament. Four changes of religion between 1540 and 1605 fuelled religious conflict and national discord. Henrician denial of papal supremacy ended with the Elizabethan state demanding total conformity. The reformation led to rebellions, social unrest and radical protests in the seventeenth century. Visible signs of those tumultuous times are still to be found in England's landscape and public space. These exist ruined monasteries - for example, Oxford and Cambridge colleges located in former cloisters, virtually no medieval stained glass from England and the so-called priest holes or priest tunnels, that is, hiding places for priests still to be seen in the principal Catholic houses of England from the period. Protests were expressed in manuscript and in print. London, a major international port, became the centre of European book smuggling and severe censorship. De Optimo Senatore ("On the Best Senator”), a famous political treatise of Laurentius Grimalius Goslicius (PL Wawrzyniec Grzymała Goślicki) (c. 1537-1607) a Polish political writer, ecclesiast and diplomat was published in 1568 in Venice and published in English translation in London in 1598 with multiple omissions on questions of Catholicism, republican political setup and critical outlook on hereditary monarchy (Bałuk-Ulewiczowa 2009, pp.12, 140-146). Goslicius' book enjoyed an enduring literary reputation and had a great political impact in the English-speaking countries, as it is known to have run into several editions and was published by William Oldisworth 
in 1773 titled Accomplished Senator. It is believed to have impacted two American founding, Thomas Jefferson and Thomas Paine.

English and Polish outstanding contributions to the constitutional and parliamentary tradition in Europe are evident in the articles of 1815 Vienna Congress. By that time most European states had constitutions, with the exception of three CentralEastern European powers - Austria, Prussia and Russia. It took a few decades until absolutist Austria and Prussia drafted their first constitutions, and it was not until 1906 that Russia adopted its first constitution. Thus, eighteenth-century partitions of Poland were executed by three absolutist states that did not recognize constitutional order.

It is worthwhile remembering that Poland's former capital, Krakow, with its royal Wawel Castle, was the seat of the king as well as the venue where the diet would convene from the sixteenth-century onwards. Similarly, the Royal Castle in Warsaw, was first of all the place where the king convened the Diet (PL Sejm) to adopt constitutions to be approved by three deliberating estates - the king, the Senate and the Envoy's Chamber. These are the visible historical proofs to the long constitutional and parliamentary tradition in Poland.

The key to understanding European constitutional tradition is the evolution of several medieval European states into estate monarchies in which the power of a prince or a king was limited not only by the natural law (divine law), papal or imperial authority, but also by the will, rights and privileges of the estates. Unanimity and consensus of various estates was the condition upon which new taxes were levied and important decisions made. The king had to secure the consent of the political estates, hence the emergence of consultations and consulting bodies, that is, estate assemblies. First assemblies to served as consulting agencies to the sovereign appeared at the turn of the twelfth and thirteenth centuries on the Iberian Peninsula. The English assembly dates back to the beginning of the thirteenth century, and the French Estates-General emerged a century later. In German lands and the Low Countries the assemblies were formed in the fourteenth century. It may thus be concluded that one of the main features of the political life of Latin Europe in the fifteenth century was limited sovereign power and estate assemblies to approve of the key political decisions in the state. Similarly, efficient estate assemblies existed in the Kingdom of Hungary, Bohemia and Poland.

In Poland the tradition of adult male gatherings or rallies (wiec) to discuss and make decisions may reflect Slavonic prehistory. Historians point out that the Slavonic tradition of the rally as a political venue of expression may be the prototype of later political practice to hold large estate assemblies.

Estate assemblies were convened by the Polish princes during the period of Poland's fragmentation in the thirteenth century. The tradition was continued after the unification of Poland under the two last kings from the Piast dynasty, Ladislas I (1261-1333) and Casimir III the Great (1310-1370). The assemblies held in various lands would have been endowed with legislative and self-governaning powers. In the same 
period the king convened country-wide meetings which passed legislation and served as advisory bodies soon to be called the general sejm (sejm walny).

Historians claim that the assemblies that took place in the towns of Sieradz, Radomsko, and Lublin after the death of Louis I of Hungary (1326-1382) may in fact be called sejm, that is, parliamentary assemblies of the estates. These were confederations convening for the purpose of securing political rights, and the decisions taken during those assemblies effected the country's political system and government. In 1386 in Lublin a decision was made to propose the Polish throne to Jogaila (c. 1352/1362-1434), the Grand Duke of Lithuania and to offer him to marry Queen Jadwiga of Poland (1374-1399). He had been crowned King of Poland in 1384 and was the heiress to the Polish crown. The royal election that took place in Lublin became henceforth the founding rule of the Polish political system.

The diet that convened in Piotrków in 1492 deliberated from January 18 until March 3, 1493. From this time onward all diets of the Kingdom of Poland and later of the Commonwealth of Poland-Lithuania were bicameral. The Upper Chamber (effectively the Senate) evolved from the royal council while the Lower Chamber (aka Envoys' Chamber) was the gathering of the deputies from the nobility estate elected at the dietines (sejmik), that is, the local assemblies of the nobility. Locally elected deputies had participated in sejm deliberations in earlier periods, but it was not until 1493 that the bicameral sejm became normalized. From 1493 until 1793 parliamentary sessions were held at more or less regular intervals and were the key element of the political system of government in Poland-Lithuania. In his seminal work Chronology of the Polish Sejm, Władysław Konopczyński listed 245 parliamentary sessions which roughly constitutes one session per less than 1,5 year.

Estate monarchy gradually evolved into constitutional monarchy and subsequently became parliamentary monarchy. The Polish system of government developed in an evolutionary way, as the sovereigns granted privileges to the nobility of the sword in order to secure their support in military campaigns, in levying taxes and in questions of dynastic succession. However, the new privileges for members of the knightly estate meant a significant increase in their responsibility for the country and in the matters of state. Bestowing of privileges was preceded by lengthy debates and disputations that constituted part of Poland's sophisticated political culture. In most cases the laws passed on those occasions confirmed to existing privileges and regulations. The long confirmed by subsequent parliaments dated back to at least twelfth century, and it would be worthwhile to mention the ones that were the most important for the emergence of constitutional monarchy.

The 1355 Privilege of Buda issued by King Louis I of Hungary listed concessions and promises to the nobility estate (szlachta) and at the same recognized their right to elect the king. The privilege was made to ensure succession of Louis and his heirs to his uncle's Casimir III the Great throne of Poland. In Buda Privilege Louis resigned from demanding financial support for his court while making royal progress in 
Poland. He also solemnly promised to compensate any losses incurred by the nobles in wars abroad.

In the 1374 Privilege of Košice, King Louis I of Hungary made new concessions to the Polish nobility to secure the future accession of one of his daughters to the Polish throne. Here the King promised to keep Polish lands intact and to regain all lands that had been previously lost. He also gave assurances he would not hand over the castles and offices of the land to foreigners. He exempted the nobility from most of the taxes and limited their military service to the cases of country defense only. The 1430-1433 Jedlna-Krakow Privilege by King Ladislas Jogaila granted members of the nobility personal and property-related inviolability and immunity as well as exemption from all dues. Moreover, the king lost the right to call general levy (pospolite ruszenie), henceforth it was the right and responsibility of the dietines.

King Casimir IV Jagiellon issued his most important privileges and charters for Lesser Poland in Cerekwica in 1454 and in Nieszawa (the so-called Cerekwica-Nieszawa Privileges). The King made a solemn promise not to levy new taxes, not to summon general levy and to seek noblemen's consent at provincial dietines when making new law. The 1496 Privilege of Piotrków issued by King Jan I Olbracht exempted the nobility from custom duty on imported and exported goods and it also granted the right of free navigation in all the rivers of the Polish Kingdom. The 1501 Privilege of Mielnik signed by Alexander Jagiellon to secure his own accession to the Polish throne after the death of his brother Jan I Olbracht expanded the powers of the Senate and henceforth the senators held much of the power in matters of state. The privilege substantially limited the monarch's power as the king was only to preside over the senate and did not have right to nominate senators. Moreover, failure by to the king to accept the decision of the senate freed the citizens from their oath of loyalty to the king.

The evolution of the constitutional system in Poland-Lithuania was concluded by the adoption of the so-called nihil novi constitution of Radom in 1505 during the reign of King Alexander Jagiellon. The original title of the constitution, Nihil novi nisi commune consensu ("nothing new without the common consent"), symbolically marked the process of constitutional and parliamentary reform. It was the moment of a fundamental political change as the constitution proclaimed that legislature would no longer be the sovereign's exclusive domain and the general bicameral diet representing the three estates would henceforth be the chief legislative authority responsible for levying taxes, issuing privileges and regulations. Lawsuits involving secular groups would henceforth be the domain of secular courts.

The list of fundamental constitutional reforms should include the law adopted in the times of the elective king Stephan Bathory. On March 3, 1578 the king resigned his prerogatives as the supreme judge in favour of the Crown Tribunal consisting of 27 noblemen deputies elected annually in judicial dietines (sejmik deputacki) and 6 ecclesiastical members elected by the ecclesiastical chapters. The Crown Tribunal (Iudicium Ordinarium Generale Tribunalis Regni) was the highest court of appeal in the Polish kingdom and the Polish-Lithuanian Commonwealth. In 1581 the Grand 
Duchy of Lithuania instituted the Lithuanian Tribunal. It was the most important judicial institution that settled matters between members of the nobility. It operated by rule of consensus in the first two votings, and the majority decided in the third voting if consensus could not be reached. Thus, in 1578 in Poland and in 1581 in Lithuania a secular high court was instituted which took over the royal judicial prerogative.

In his seminal study on the history of Polish law and statehood, Wacław Uruszczak argues that constitutional monarchy was formed in the Jagiellonian state as a result of evolution after the adoption of the Nihil novi constitution by the Sejm in 1505 (Uruszczak, 2015, Uruszczak, Baran, Karabowicz ed. 2007). The Nihil novi constitution introduced parliamentary system of governance and set the foundation of a state based on the rule of law where the law ruled and not the people. It also set the basis for a state of free citizens and introduced the principle of parliamentarism into PolishLithuanian political life, which meant collective law making and the need for any law to be promulgated. The Nihil novi constitution marked the beginning of modern constitutionalism in Poland and in Europe at large.

The Radom Sejm further ordered the Chancellor and Primate Jan Łaski to codify the fundamental statutes and privileges of the Polish law. Łaski's Statute was published in 1506 in Krakow. It was a collection of publicly issued constitutions, decretals, edicts and statutes, and it was the first ever official codification of law published in the Kingdom of Poland.

The 1569 Union of Lublin was a milestone in the history of governance system in Poland and Lithuania. A formal Act of Union was sealed by the King and signed by the representatives of the noble estates of the Kingdom of Poland and the Grand Duchy of Lithuania during the general sejm in Lublin. The Act of Union set the political framework of a state henceforth to be called the Commonwealth of the Two Nations. There was to be a real union between the Kingdom of Poland and the Grand Duchy of Lithuania with one coat of arms, one sejm, one foreign and defence policy and one currency. Lithuania kept its own treasury, offices, and administration, army and courts (Davies, 2013, p.121). The king was to be elected in free election and crowned king of Poland in Krakow. General Sejm was instituted to convene in Warsaw. The Senate would consist of 113 senators from Poland and 27 senators from Lithuania, the Envoy's Chamber would consist of 120 deputies from Poland and 48 deputies from Lithuania. The Act of Union passed the unification of legal system. Interestingly, the document was closely studied at the English Court of Queen Elizabeth I when EnglishScottish Union was drafted in 1603 (Tomaszewska, 2009, p.95).

After the death of the last Jagiellon King Sigismundus Augustus in 1572 two laws were passed that affected the system of governance: the Warsaw Confederation (1573) and the so-called Henrician Articles (1573). The Act of Warsaw Confederation was a constitution-like document promulgated for the community of citizens. It was the expression of the political will of the political nation of the nobility and as such it confirmed the importance of the rule of law in the public sphere, it also established the free election of the king to be attended by the entire nobility carried out in 
concordance and on a viritim basis. It introduced the principle of religious tolerance in the political system of Poland-Lithuania, which was a remarkable achievement in a multi-religious state.

Henrician articles were in fact considered eternal constitution of the Commonwealth of the Two Nations, which was effective until the end of the eighteenth century. The articles spelled out the competences and areas of power of the elective kings as well as their relations with the Chamber of Envoys and the Resident Council of Senators. In a word "it warranted the grounds of the State's political system" (Tomaszewska, 2009, p.46). Every subsequently elected king was obliged to swear on the Articles. In addition, in times of free election the so-called pacta conventa ("articles of agreement") were drawn up in a form of a contractual agreement between the newly elected king and the country's political nation. Each newly elected king was obliged to sign the articles and thus express his respect for the laws of the Commonwealth as well as to make clear his undertakings in the realms of foreign policy, taxes, and defence. Pacta conventa were thus "a collection of constitutional norms and regulations drawn by the members of the Sejm during the convocation Sejm. They specified the most important goals of domestic and foreign policy and were a binding document for the period of the elective king's term of office" (Konstytucje Rzeczypospolitej www.trybunal.gov.pl).

The Government Act, or the so-called Third of May Constitution, was passed in the course of the Four Years' Sejm in 1791. Although it was adopted with some procedural mistakes, it was nevertheless accepted by the dietines. It introduced tripartite division of powers, strengthened royal power and substantially reformed the administration. The Constitution was supplemented by three other constitutional acts which complete the process of the reforms in the Commonwealth, namely the Act on Towns (March 18, 1791), the Reciprocal Guarantee of the Two Nations (October 20, 1791) and the Constitution of the Duchy of Courland and Semigallia (May 1792). After the Polish-Lithuanian Commonwealth ceased to exist as a result of partitions in the eighteenth century, the only other constitutional project that may be considered a continuation of the previous constitutional tradition was the 1807 Constitution of the Duchy of Warsaw promulgated by Napoleon Bonaparte. It introduced the civil code, or the so-called Napoleonic Code based on Roman law.

Several later constitutional regulations pertaining to the partitioned Polish-Lithuanian territories should be listed, among them: the Constitution of the Kingdom of Poland, a state created out of the Duchy of Warsaw at the Congress of Vienna. Tsar Alexander I of Russia promulgated the constitution for this part of the occupied Polish territory on November 27, 1815. Other constitutions adopted in the partitioned territories included the Constitution of the Grand Duchy of Poznan (1815) and the Constitution of the Free City of Krakow $(1815,1833)$ as well as the Acts of the November Uprising such as the Address of General Józef Chłopicki (1830), which explained the necessity to introduce war dictatorship and called upon the nobility to defend constitutional rights and freedoms. The Act of Deposition of Russian emperor Nikolai 
I Romanov from the Polish throne as well as a joint act of November 29, 1831 promulgated by the united Sejm Chambers instituted National Government as well as described its system and competences.

Massive collection of constitutional acts listed above undoubtedly bears witness to one of Europe's richest constitutional traditions. Parliamentarism and constitutionalism were so much part of the Polish political identity that the three absolutist monarchies involved in the partitions of Poland decided to introduce constitutional system of governance in some parts of the occupied territories. This was the case in Russian-dominated Kingdom of Poland where one of the most liberal constitutions was drafted by prince Adam Jerzy Czartoryski as well as in the lands under Prussian occupation (the Grand Duchy of Poznań) and in the Austrian territories (the Free City of Krakow).

Given the long-standing Polish constitutional tradition, it comes as little surprise that the Poles contributed significantly to the political reforms of the Austro-Hungarian Empire, especially in the financial sphere, thanks to the involvement of Julian Dunajewski, Austro-Hungarian Minister of the Treasury. They also contributed to the development of the Austro-Hungarian constitutional sphere through the proclamation of the December Constitution in 1867, which granted autonomy and freedoms to various parts of the empire.

The development of constitutionalism was accompanied by the development of parliamentarism as well as by the unprecedented political participation in the sixteenth and seventeenth century. According to Richard Butterwick, the development of the political culture of the Commonwealth of Poland-Lithuania was unmatched by the political culture of any other country as not only was it based on efficient Diet and dietines but also on active participation of large groups of nobility in the public life (Butterwick, 2005, 2007). The nobility made up 7 to 10 percent of the entire population of Poland-Lithuania (in Mazovia region it reached up to 30 percent). Nobility was a numerous estate whose only foreign equivalent was Hungarian nobility. In contrast, only 5 percent of population received the vote in the 1832 Reform Act in England - the mother of parliamentarism.

Estate monarchies produced a long list of rules, regulations, privileges and rights that guaranteed freedoms and autonomy to subsequent estate, towns and guilds. Near the end of the Middle Ages, kings, princes and communities sought independence from emperors and Popes. On the other hand, some sovereigns were strengthening their position by centralising their states. The nation states that emerged during that period were accompanied by three concepts: the state, sovereignty, and national interest. Machiavelli's The Prince introduced the concept a modern state (lo stato). The theory of sovereignty and reason of state was discussed by Jean Bodin in his work The Six Books of the Republic. The formation of modern state was further facilitated by the Reformation, which led to multiple conflicts, religious wars and eventually prompted religious leaders to seek protection of princes and kings. In Protestant states kings protected a new Christian denomination provided they would head the new 
churches. In Catholic states, to the contrary, the sovereign gained complete control of the country and church (josephinism, gallicanism). These processes accelerated changes and centralization of the emerging nation states and, as a result, absolutist monarchy became the prevailing system of governance in the seventeenth-century European nation states.

Some estate monarchies transformed in an evolutionary way. The Late Middle Ages witnessed a revival of classical literature; the lost works of Aristotle including Politics were translated from Arabic in the thirteenth-century Florence area; the works of the Roman writers, Cicero, Polibius, Tacitus were back in the shelf. These trends facilitated the emergence of the city republics in Italy, especially Venice, in selected German towns and in the Republic of the Seven United Netherlands as well as in Russian Novgorod the Great. However, it was the Polish-Lithuanian Commonwealth, which was the largest republican project in the world before the emergence of the United States of America.

The Jagiellon state, unlike the rest of Europe, did not know the cuiusregio, eiusreligio rule; on the contrary, the motto for this part of Europe could be the famous words of King Sigismundus Augustus who famously declared in the Sejm: "I am not the king of your consciences.” The Jagiellon state did not suffer from religious persecution and remained a multi-ethnic and multi-religious state well into the eighteenth century. The state was conceived as a continuation of the Roman republican tradition, the respublica mixta, a state which was a political community of free citizens whose duty was to abide by law. All law making was accompanied by the deepest respect for Christian rules and principles. It was the Christian doctrine of love and mutual respect that translated into the concept of peaceful coexistence among nations as a doctrine in international law and politics. This pioneering notion was expressed by Paulus Vladimiri (ca. 1370-1435), rector of the Krakow Academy, when he spoke at the Council of Constance (1414-1418). It is thanks to adopting Christian principles in the public life and in legislature that natural law prevailed. While acknowledging the contribution of various countries to the development of parliamentary and constitutional traditions, it is worthwhile remembering the extraordinary Polish heritage pertaining to this area of politics. The Polish-Lithuanian Commonwealth turned out to be the precursor of numerous systematic solutions in state governance. It is an inspiration and a moving testimony to rich political culture.

\section{Bibliography}

Balzer, O. (2009). Geneza trybunatu koronnego. Warszawa: Muzeum Historii Polski.

Batuk-Ulewiczowa, T. (2009). Goslicius' Ideal Senator and His Cultural Impact over the Centuries: Shakespearean Reflections. Polska Akademia Umiejętności: Kraków.

Bardach, J. (Ed.) (1997). Dzieje Sejmu Polskiego. Warszawa: Wydawnictwo Sejmowe.

Butterwick, R. (2005). Political Discourses of the Polish Revolution, 1788-1792. English Historical Review, 120.

Butterwick, R. (2007). I Rzeczpospolita dzisiaj. Pressje, 10-11. 
Davies, N. (2013). God's Playground. A History of Poland. Vol. 1. Oxford: Oxford University Press. Frost, R. (2015). The Oxford History of Poland - Lithuania. Vol. 1. Oxford: Oxford University Press. Grodecki, R., Zachorowski, S. and Dąbrowski, J. (2011). Dzieje Polski średniowiecznej. Vols. 1-2. Krakow: Universitas.

Gutkowski, J. (1996). Sejm polski. Warszawa: Wydawnictwo Sejmowe.

Heck, R. (1997). Polska w okresie monarchii stanowej (1346-1454). Wybór tekstów źródłowych fragmenty. In Wiek V-XV w źródtach. Wybór tekstów źródłowych z propozycjami metodycznymi nauczycieli historii i studentów, ed. Melania Sobańska-Bondaruk, Stanisław Bogusław Lenard. Warszawa: Wydawnictwo Naukowe PWN.

Kaczmarczyk, Z., and Leśnodorski, B. (1957). Historia państwa i prawa Polski od połowy XV w. do r. 1795. Warszaw: PWN.

Kaczorowski, P. (2006). Nauka o państwie. Warsaw: Wydawnictwo SGH.

Kallas, M. (1996). Historia ustroju Polski X-XX w. Warszawa: Wydawnictwo Naukowe PWN.

Konopczyński, W. (1948). Chronologia sejmów polskich 1493-1793. Kraków.

Konstytucje Rzeczypospolitej XVI - XX wiek, Trybunat Konstytucyjny, Warszawa,

www.trybunal.gov.pl;http://wszechnica.trybunal.gov.pl/Konstytucje\%20RP_wystawa.pdf; Accessed on 30.09.2015.

Lewandowska-Malec, I. (2009). Sejm walny koronny Rzeczypospolitej Obojga Narodów i jego dorobek ustawodawczy. Kraków: Księgarnia Akademicka.

Michalski, J. (1984). Historia sejmu polskiego. Vol. 1. Warszawa: Wydawnictwo Naukowe PWN. Tomaszewska, E. (Ed.) (2009). Poland. The Heritage of Pariamentarism until 1791. Brussels. Uruszczak, W. (2015). Historia prawa i państwa polskiego. Wolters Kluwer: Warszawa.

Uruszczak, W., Baran, K., Karabowicz, A. (Eds.) (2007). Podział władzy i parlamentaryzm w przeszłości i wspótcześnie: prawo, doktryna, praktyka: 500 rocznica konstytucji Nihil novi z 1505 r.: 56 Konferencja Międzynarodowej Komisji Historii Instytucji Reprezentatywnych i Parlamentarnych w Krakowie i Radomiu, (5-8 września 2005). Warszawa: Wydawnictwo Sejmowe.

Witusik, A. (Ed.) (2004). Unia Lubelska 1569 roku w dziejach Polski i Europy. Lublin. 


\section{Igor D. Osipov ${ }^{1}$ and Leonid V. Smorgunov ${ }^{2}$}

\section{Russian Constitutionalism}

The conceptualization of the theoretical and ideological foundations of constitutionalism is related to specific aspects of the methodology of humanities and, in particular, philosophy. The discussion of philosophical and legal premises of the constitutional process not only touches on legal and political issues, but also raises philosophical and ideological issues. The principles of the rule of law, democracy, separation of powers, civil society, inalienable rights and freedoms developed in philosophy and embodied in modern constitutions are an important criterion for assessing the level of development of the state and social progress. The political and legal aspects of development that were previously inherent in European societies have now turned into an international norm. First of all, this is the case with constitutionalism, which is comparable with the paradigm of a social ideal of society. The idea of a rational and harmonious society and state can be found as early as the works of Plato and Aristotle. The Hellenes distinguished between political integrity and the basic principles of its organization and existence. The Romans, in turn, stressed the visual materiality of the natural, artificial and abstract political orders.

In the Modern Age in Western Europe, the idea of constitution was interpreted using the expressions, such as "form", "composition" and "association of republics." In 1733, Lord Bolingbroke gave a classic definition of constitution as follows: "By constitution we mean, whenever we speak with propriety and exactness, that assemblage of laws, institutions and customs, derived from certain fixed principles of reason, directed to certain fixed objects of public good, that comprise the general system, according to which the communality hath agreed to be governed" (Bolingbroke, 1809, p.157). Theoretical and practical philosophies converge in the concept of constitution as an idea of reasonable structure of society to unlock the creative potential of the pragmatic philosophy. The Age of Enlightenment saw the development of theoretical foundations of the modern rule-of-law state, democracy and civil society. A rational view on society has given rise to the philosophy of law as a theoretical premise for the modern constitutionalism. In general, a philosophical analysis of the concept of "constitution" can identify global trends in the development of human society as a culture and civilization.

In Russia, the constitutional ideas emerged in the first half of the 17th century, were developed to some extent in the 18th century, in particular during the enlightened monarchy of Catherine II, and became more or less completely established in the 19th and early 20th centuries. Typical in this respect are the constitutional ideas

1 St. Petersburg State University.

2 St. Petersburg State University. 
held during the reign of Alexander I in the first third of the 19th century. Those developed into the so-called noble constitutionalism, which manifested itself in activities of the Chancellor Alexander Vorontsov and projects of Mikhail Speransky, as well as the constitutional projects of the Decembrists Nikita Muravyov and Pavel Pestel. The second wave of interest in constitution took place in the second half of the 1850s, especially during the reforms of Alexander II. Finally, the first Russian revolution of 1905 and all related movements for political representation and limitation of the monarchy put the issue of constitution back on the agenda. Despite the availability of constitutions during the Soviet period, constitutionalism developed as a theoretical movement and constitution action as late as the 1960 s and thereafter, albeit its philosophical and ideological foundations had been laid by the constitutions of the 1920s and 1930s (and related debates). Some scholars refer to the "nominal constitutionalism” during the Soviet times (Kravets, 2005, p.95; Medushevsky, 2015, pp.121-122), but we see this as roughening the situation and consider Soviet constitutionalism as a freestanding rather than a nominal phenomenon. In addition to the official Soviet constitutionalism, there were constitutional ideas of the dissident movement and legal liberalism during the perestroika period, which, in a sense, create a platform for the modern constitutionalism. However, the adoption and application of the Constitution of 1993 added special dynamics to the understanding of the modern constitutionalism in Russia.

Russian constitutionalism is one of the topics presented in Russian studies. A picture of Russian constitutionalism in the history of imperial Russia is pretty good considered. Especially it is noticeable in the works on the history of Russian liberalism (Fisher, 1958; Walicki, 1992; Hamburg, 1992; Balmuth, 2000), though some research expresses scepticism to the ideas of constitutionalism during the period in question (Dorosh, 1944; Sanders, 1992). Of course, the attention of researchers has been attracted to the events of 1905-06, when constitutionalism and political ideas were embodied in a number of institutional reforms of autocracy (Hosking, 1973; Fröhlich, 1981; Weber, 1995; Enticott, 2016). The study of Soviet constitutions is also variegated; here the notable works are those related to the display of the limits of constitutionalism under socialism (Brecht, 1937; Unger, 1981). The study of modern Russian constitutionalism is held in line with the theories of post-Soviet transit. Much attention has been paid to the general description of the constitutional foundations of the post-Soviet development of Russia (Sharlet, 1993; Ordeshook, 1997; Clark, 1998; Henderson, 2011). Special consideration has been paid to the themes of constitution and the presidency, the interaction of religion and state, federal structure, and constitutional review (Brzezinski, 1993; Sharlet, 1994; Fogelklou, 2003; Scheppele, 2003; Basil, 2009; Flere, Lavrič, Djordjevič, 2016). Additionally, there are works on the comparative analysis of concepts, rhetoric and genre of the Soviet and modern Russian constitutions (Ruutu, 2010; Schmid, 2010).

This essay outlines the development of constitutional ideas in Russia, representing Russian constitutionalism from the perspective of ideas-movements accompanying 
the organization of Russian society in the state, including the opposition to it, rather than in a historical vein. In this respect, modern constitutionalism in Russia can be seen as mixing pre-revolutionary traditions of liberalism (mostly liberal conservatism), the Soviet legal consciousness and pragmatic attitudes of political struggle in the transitional period. In a sense, the authors of the article employ the methodological approach of "path dependence," choosing to analyze the three main periods of Russian constitutionalism, when it became not just a wish, but was put into political practice. In this way, philosophy of law and the relation to the constitutional ideas of the 19th and early 20th centuries are accompanied by attempts to institutional and legal reforms in the history of imperial Russia under Alexander I, Alexander II, and Nikolay II. Soviet constitutionalism, rejecting the liberal trend of Russian constitutionalism, forced yet to establish legality and laws, albeit in a specific form. As Peter Ordeshook writes, "constitutions matter even for states without a democratic tradition” (Ordeshook, 1997, p.50). The current Russian constitutionalism remains controversial and incorporates many of the previous constitutional moods. Dissident constitutional ideas, which are also referred to in this article, only partly provided an ideological basis of modern constitutional history of Russia. In any case, the idea of Russian constitutionalism was an important engine for the organization of a state and public life. In general, we can agree with Ulrich Schmid that "constitutional narrative with its implicit genre and rhetoric must be understood as the core of the identity of any given society that chooses to organize itself through legal procedures within the framework of a state” (Schmid, 2010, p.450).

\subsection{Philosophy of Law and Constitutional Ideas in the 19th and}

\section{Early 20th Centuries}

The concept of constitution reflects not only the universal, but also individual things in life that are driven by social traditions and customs. This includes the basic values of society that prescribe a certain way of taking top positions and the scope of their authority, and also grant the right to use force. What is important is that as the basic law, the constitution is linked to the value-based structure of the society. Constitutions of modern states are specific and distinct in terms of history and culture; hence they have some national specificity. This is confirmed by a great diversity of constitutional norms and provisions, revealing the creative potential of constitutionalism as a process of concretization through the practical implementation of its provisions. The development of state institutions depends on the political culture and people's mentality that have been shaped over centuries. One of the prominent Russian constitutionalist lawyers of the early 20th century Vladimir Geriye wrote: "Is there any absolute constitutional law binding on all countries and in all times? Are politics (in the sense of governance of the state) an abstract theory, rather than a live art which 
should proceed from and conform to the reality as any other art does?” (Geriye, 1996, p.140). The constitutional process should take into account not only the panhuman content of the constitution, but also specific conditions in which constitutional provisions are drafted, given the system of values in the mentality of the people in a particular society. This comprises the rational aspect of constitutionalism as a real problem of state-building that requires that close attention be given to axiological and spiritual foundations of the rule of law.

In Russia, the current constitutional process is to some extent similar to what was the case before the revolution when Russia had a strong law school that was famous in Europe, with outstanding representatives such as Alexander Gradovsky, Maxim Kovalevsky and Sergey Muromtsev. In our opinion, however, the tradition of the philosophy of constitutionalism in Russia begins with Mikhail Speransky - close associate of Alexander I during the period of his liberal reforms. Speransky is the author of the first Russian textbook on constitutional law and made a significant contribution not only to the development of the theory of constitutionalism, but also to the practical creation of the legal and constitutional order based on the European and Russian standards and principles of political science.

The Russian philosophy of constitutionalism discussed problems such as the abolition of serfdom and building a class-free society, and offered two most common interpretations of constitution: constitution as the basic law of a country and as a law that protects the society from unlawful actions of the state power. Accordingly, we can say that the Russian philosophy of law has the "constitutionalism of love" for and confidence in the state and the constitutionalism of apprehension of the state as a threat to the development of law and freedom in society. Different philosophical and legal doctrines were developed by solving these issues.

The first one was liberal, with different individual stages of development. In general, liberal constitutionalism recognized the importance of personal rights along with voluntary self-limitation of the autocracy. Speransky played an important role in the establishment of this line of constitutionalism. In the first decades of the 19th century, he called for the vertical and horizontal separation of powers and the superiority of law with specific features determined by the actual conditions of development of Russia. Those included the development of ethics of law and power, the preservation of personal freedoms in the economy and private ownership, as well as legal education of people and availability of national code of laws and autocracy.

What was of fundamental importance to Speransky is the step-by-step nature of the constitutional process in Russia. He believed that "one of the main rules for governors is to know their people, know the time" (Speransky, 2002, p.261). This knowledge will help implement reasonable constitutional reforms, while maintaining the autocracy; and the limits of the autocratic power should be set by itself "by treaties of the government from the outside and by the imperial word from within" (Speransky, 2002, p.61). According to Speransky, "the Russian Constitution will be brought into being not by the inflamed passions or extreme circumstances, but by the beneficent 
inspiration of the supreme power, which, having arranged the political being of its people, can shape it appropriately and has all the means to do that" (Speransky, 2002, p.342). Speransky's ideas not surprisingly met with resistance from conservatives, who viewed them as too radical. As noted by David Sanders, "if these were the objectives towards which Speransky was striving, in the Russian context he was a red-hot radical... He called his goal 'true monarchical government' - the monarchy of Montesquieu rather than the monarchy of the tzars" (Sanders, 1992, p.63).

The liberal form of constitutionalism was relatively underdeveloped in Russia. A more fundamental type of constitutionalism was the one that brought together the requirement for personal freedom and traditional values of Russian society. It can be described as liberal-conservative. This kind of Russian liberalism has been woken up to political activity after the death of Nicholas I, and the expectation of the reforms of Alexander II. Obvious representatives of conservative liberalism in the mid- to later19th century were Konstantin Kavelin and Boris Chicherin, and the beginning of the 20th century, Pyotr Struve.

A representative of this type of constitutionalism, a prominent Russian lawyer, professor at Moscow University, and later the St. Petersburg University, Kavelin explored the problem of constitutionalism in the context of development of a people's monarchy or autocratic republic (Kavelin, 2008, p.261). He was questioned and found wanting the ideas of noble constitutionalism and people's representation. According to Kavelin, the constitutionality of the people's monarchy was based on the unity of the tsar and the people, expressed through a combination of the rule of law and local initiatives. He distinguished between constitution in the broad and narrow sense. In his work entitled "The Nobility and Liberation of Peasants," he wrote: "In the broad sense, constitution is understood as any proper structure of the state and society, which is based on reasonable, invariable foundations and laws - a structure that leaves no room for arbitrary action and where the identity, property and rights of each and every one are secured and inviolable” (Kavelin, 1989, p.151). In the narrow ("tight") sense of the word, he understood constitution as a political order based on the representation of interests and separation of powers (Kavelin, 1989, p.152). Thus, Russia first of all has to realize the need for a constitution in the broad sense of the word. He was more interested in the interior improvements than in representative governance. He believed that there was a need for "a strong and well-structured court, the freedom of speech, and the transfer of the administration of everything that is not directly concerned with the unity of the state to local communities. There is a need for a constitution in the broad sense. It is necessary to create a structure of the state based on reasonable foundations and laws that would leave no room for arbitrary action and property, and other rights of individuals are inviolable” (Kavelin, 1989, p.152).

A professor of Moscow University, Chicherin spoke of a constitutional monarchy governed by the rule of law. This understanding came to him as a result of his assessment of the development of Western liberalism. Chicherin scholar Gary Hamburg shows the evolution of such views and political positions: "Chicherin's development 
from pre-emancipation liberal into post-emancipation conservative liberal was rather the result of his continuing articulation of the conservative elements latent within juste-milieu liberalism... In Chicherin's understanding, European liberalism entailed hostility to revolutionary utopianism, rejection of arbitrariness, and adherence to the rule of law. Therefore, Chicherin could be quite sincere in equating 'true liberalism', 'conservative liberalism', and 'rational conservatism'” (Hamburg, 1999, p.271). In this case, constitutionality meant representative governance combined with the will of the monarch. As Chicherin wrote: "It also follows from the essence of the matter that only constitutional monarchy is a perfect representative structure for Russia. There should be no doubt for us what should be chosen between the two forms that embody political freedom - limited monarchy or republic" (Chicherin, 1998, p.508). For him, the basis of the state which "is a product of national identity" is not the ends, but the means. The goal is to preserve a strong and effective structure of the state, while ensuring that government will not interfere with the economy. Much in this field should be given for free activity of man. Chicherin's philosophy of law was based on the unity of freedom and power and considered "a free man in a free society" and "a balanced democracy" as an ideal.

Finally, worth mentioning here is the philosophy of law offered by Pyotr Struve. Struve has moved from legal Marxism in the late 19th century to the conservative liberalism of the early 20th century. His philosophy was based on the ideas of the preservation of the power of Russia as an empire. For him, constitutionalism was closely related to patriotism, recognition of the priority of the basis of the state, and protection of individual rights and freedoms. According to Struve, "With people who have come to movement, whose constitution was born from the spirit of patriotism disturbed by severe state losses rather than from radicalism inspired from the outside, you cannot achieve anything by a simple order of the power" (Struve, 1997, p.61). Another important postulate of Struve's philosophy was the one about personal suitability - the discipline of work for all the social strata. "The ruling circles should know that if great Russia is to come out of great upheavals, then you need a creative feat of all of the people," he wrote (Struve, 1997, p.55). Struve and other outstanding representatives of this school, such as N. I. Kareev, S. A. Muromtsev, V. I. Geriye, M. M. Kovalevsky, E. N. Trubetskoy, and other prominent Russian lawyers, contributed to the creation of the Constitutional Democratic Party who had developed the Russian constitution in the early 20th century. Let us also note that the thinkers of this philosophy of law were positive about the European experience of constitutionalism.

The third point of view on constitutionalism was presented by conservatism in the views of M. N. Katkov, I. S. Aksakov, V.N. Leshkov, L. A. Tikhomirov, K. N. Leontiev, K. P. Pobedonostsev, and P. A. Stolypin. The key value of conservatism was that of the public order and power, while denying the need for a constitution that limits state power. In conservatism, the philosophy of law put emphasis on traditions, customs, the moral content of law, the synthesis of the Orthodoxy and the state in the political system, the denial of democracy, and the rule of law in the form developed in Western 
Europe. Conservatism criticized the formalism of constitution as a text, while affirming the actual structure of the state - autocracy in this case. Political realities were understood on the basis of the principle of the unity of land and the tsar. In legal sense, this manifested itself in the supremacy of the autocratic power and duties to it. As Mikhail Katkov put it, "the duties already comprise rights, the duties are always accompanied with rights...A right that is not covered by a duty is easily brought far ahead, leaving the baggage of duties behind. The promises to give us a constitution are baseless - the constitution is already there in our oath to the state which obliges every Russian citizen to take care of the benefits of the Emperor and the state" (Katkov, 2008, p.323).

At the same time, conservatism assumed the functional separation of powers, while maintaining the dominant role of the autocracy in the state. From this perspective, human rights, democracy and independence of the court were subject to the principles of state law. In general, the conservative constitutionalism underlined the need for maintaining the unity of the Russian state, traditions, the way of life and religious principles in the society. Therefore, the criticism of the Manifesto of October 17 - the basic laws of 1906 (which, in fact, were the first Russian constitution) by the conservatives seems to be logical.

Finally, the fourth school of Russian constitutionalism is radicalism: the narodnik movement and Marxism. Without denying the idea of constitutionalism in principle, the narodniks Pyotr Lavrov and Pyotr Tkachev supplemented it with a provision on the need to protect the rights of the peasantry. In Russian Marxism, the same approach took the form of the class-based concept of law and state, defending the rights of the working class. The right to work and social security was an important premise for the concept of state and law in radicalism. It is only notionally that the philosophy of law in revolutionary socialism (Alexander Herzen, Mikhail Bakunin, Nikolai Chernyshevsky) can be referred to as law-related. It criticized the formalism of the constitutional law of the bourgeoisie, was, to a certain extent, socially egalitarian, and supported the ethics of social justice. Alexander Herzen wrote: "What respect can we have for your Roman-Barbarian rule of law - an awkward building without light and air that was renovated in the Middle Ages and whitewashed by the emancipated petty bourgeoisie? I agree that the daylight robbery in the Russian courts got even worse, but this does not mean that your laws and courts provide justice" (Herzen, 2012, p.475). If they talked of a new constitutional order, it was the one based on morality, ancestry, statelessness and natural justice. In Statism and Anarchy, Mikhail Bakunin pointed out that no constitution, even the most liberal and democratic one, can eliminate the contradiction between the people and the imperial state in Russia. "There is only one constitution that people can benefit from. It is the destruction of the empire" (Bakunin, 1989, p.356).

To summarize the discussion on the philosophy of constitutionalism before the revolution, we must admit that all the political parties that contributed to the constitutional process in pre-revolutionary Russia were uncompromising and lacked 
confidence in each other. However, Speransky wrote that the constitution should be based on a compromise between various social forces. Unfortunately, the pre-revolutionary Russian political elite did not have enough political wisdom, which had led to revolutions. It should also be noted that the pre-revolutionary society demonstrated low levels of political and legal consciousness, legal nihilism of the authorities, intelligentsia and bureaucracy. The society clearly lacked a 'normal' sense of justice, a culture of freedom in combination with responsibility, and a civil society supported by an appropriate legal culture. In addition, the constitutionalism in Russia was influenced by paternalism in the perception of power. The tsar was seen as the symbol of the highest truth and justice, while public servants, in the opinion of the intelligentsia, were the ones who concealed the truth both from the people and the tsar, hampering the communication between the people and the ruler.

\subsection{Ideas of Soviet Constitutionalism}

The Constitution of the Russian Soviet Federative Socialist Republic of 1918 was developed and adopted in the period that the Soviet historiography refers to as "war communism." This was the first constitution to lay down the structure of the state of the soviet type, although its significance is not only related to state regulations. It was the war communism that left a serious imprint on its content and form. The linkage between constitutional issues and policies was not accidental. On the whole, one must agree with Katja Ruutu that Soviet and Russian conceptual history of constitutions is more multifaceted and more political in nature than commonly thought (Ruutu, 2010, p.77). The constitutions of the USSR subsequently adopted in 1924, 1936, and 1977 maintained a certain ideological continuity. The Constitution of 1918 mainly expresses the philosophy of law in the period of "immediate construction of communism" using military and political means. However, the general principles of constitutional building established at that time were, to one extent or another, reproduced in the Soviet constitutions of later periods.

Historically, the "war communism" coincided with the first political period of socialist construction. On the one hand, war communism policy was determined by specific causes that contributed to the development of a revolution in the context of the civil war, foreign military intervention and economic devastation. In terms of material production and distribution, this period was characterized by the following policies: requisition of agricultural surpluses from peasants by the state either partially in exchange for food or for free as a payment for the protection against restoration of landowners' estates; nationalization of the industry by the Soviet state and the introduction of strict centralized management (glavkizm); class-based rationing of food on the principle of "he who does not work shall not eat"; private trade banned; provision of the population with food and consumer goods almost for free, in exchange for work (wage naturalization); rigorous control of the quantity and quality 
of the output and egalitarian distribution; money replaced by barter ("withering away of money"); engaging all the able-bodied population in work on the basis of labor conscription (the militarization of labor) (Berkhin, 1970; Gimpelson, 1973). On the other hand, this policy was often interpreted not only as a coercive measure, but also as a means of socialist construction.

In 1921, Vladimir Lenin admitted that the ideological origins of the transition to communism were associated not only with the spirit of war, but also, to a great extent, with the overall theoretical platform of the Bolsheviks before and after October 1917. At that time, the theory of socialism was developed as a radical negation of capitalism and immediate socialist construction. At the seventh Moscow Gubernia Party Conference, Lenin said that "If you remember the statements, both official and unofficial, that our party made between late 1917 and early 1918, you will see that even then we expected that the development of the revolution, the development of the struggle might be either relatively short or very long and difficult. But when we assessed the possible development, we proceeded for the most part (I do not even remember any exception) from the assumptions that were perhaps not always openly expressed, but always tacitly assumed - the assumptions regarding the direct transition to socialist construction" (Lenin, 1974, p.197). The ideology of immediate construction of socialism using radical means has left its imprint on the understanding of many processes, including the constitution-building process. A member of the Constitutional Commission in 1918, and a member of the Bolshevik faction in the All-Russian Central Executive Committee, Mikhail Pokrovsky eloquently wrote about this period as follows: "It seemed what we were able to do so brilliantly on the military front, we would also be able to do in public education and in the economy... I will say this frankly, because this is something that I experienced myself: we were besotted with this speed. It moved at such a pace that it seemed we were very close to communism - the communism created by our own means, without waiting for the victory of the proletarian revolution in the West” (Lunacharsky, Pokrovsky, 1925, p.21). Another member of the Constitutional Commission of the Bolsheviks Nikolai Bukharin confirmed that the "war communism" was not conceived as "military," that is, only suitable at a certain stage of the civil war, but it was seen as a universal, general and normal form of economic policy of the victorious proletariat (Bukharin, 1924, p.4).

The revolutionary sense of justice was based on the positivist attitudes to law as an expression of the public will. At the same time, powers of the state were viewed from the perspective of classes. Law was established by the state as a tool for the regulation of social relations for the benefit of the ruling class. Justice was seen as the will of the ruling class given the force of law. No natural justice was recognized, and positive law was a rational tool for resolving political problems. The old bourgeois law, as well as the state, was considered as an expression of the will of the bourgeoisie and had to be destroyed in the context of the socialist revolution. In this respect, it was believed that the ruling will should not be limited or subjected to assessment in terms of the universal legal justice. Laws approved and supported by the power of 
the state were considered equitable if they were in line with the revolutionary tasks of the proletariat, that is, the tasks of overthrowing capital and establishing socialism. The principle of the rule of law was seen as a relic of the religious consciousness that was formally expressed by bourgeois democracy. This is how the principle was assessed by the well-known legal expert of the time Evgeniy Pashukanis: "The rule of law is a mirage, but it is a mirage that is very convenient for the bourgeoisie, because it replaces the weathered religious ideology" (Pashukanis, 1924, p.111).

The negation of the natural legal philosophy was accompanied by the criticism of the contractual concepts of law and the rule-of-law state. It was believed that a contract only established a formal equality of the parties, while actually they were unequal and one class exploited the other. Therefore, contractual law was deemed false and needed to be abolished. It was argued that legal relations were abstract and therefore the creation of a legal superstructure must be based on the real relations. This attitude gave rise to a problem of balance between expediency and law. Razumovsky wrote, "Formalism in both the understanding and application of the legal form becomes harmful when it comes to expediency. You should not confuse the legal possibility given by formal equality and its actual use. A legal rule put forward as a principle by the proletariat who use it can make sense in its legal abstraction, as a legal guarantee protecting the right of the minority, etc. But it must not be identified with its practical use" (Razumovsky, 1926, p.48).

Revolutionary legality was based on the subordination of law to politics and revolutionary expediency. The instrumental nature of law was supplemented by the principle of relativism, where law did not justify the recognition and sustainability as such and thus was seen as a volatile structure that was constantly changing under the influence of revolutionary goals. In this case, there was no need for constitutional supervision and control, because the constitution is not long-term, but is subject to the revolutionary process of change. According to one of the developers of the first Soviet Constitution Professor Mikhail Reisner, Russia needed a flexible and versatile constitution that would not allow for "fixing upon fossilized forms." To this end, it was "built not on the basis of legal law, but rather on the basis of expediency and teleology that allow for filling it with any content". He further emphasized that "when we say that our constitution is based on the idea of purpose and expediency, we mean that our basic law does not embody immobility and dead justice ... but rather represents a blueprint, a plan of social construction ... And such a plan does not purport to be infallible." "Accordingly, our attitude to the basic law, or constitution, will be completely different from that found in the case of a strictly law-based constitution. While in the latter case, the main task is to interpret and apply a law that has been established once and forever and then customize any other or absolutely new cases to fit it, we, in the first place, have to continuously criticize and work to improve the constitutional law," concludes Reisner (quoted in Mityukov, 1996, p.11).

The Soviet Constitution of 1918 was developed in the context of the development and reinforcement of the so-called revolutionary legality that had to serve the tasks 
of the immediate construction of socialism using military and political means. At the same time, it was a historically significant event, as it was the first Russian constitution that defined the structure of the state in the form of a system of soviets and the goal of political development - building socialism. It was constituent in nature, since it provided a basis for shaping the political and legal realities of the time. The constitution was a political instrument laying down the tasks of the authorities and mobilizing to achieve them. It was of legal significance, because regardless of many illusionary and non-legal aspects, it still served as a regulatory basis for building the main branches of Soviet law (such as criminal, civil, administrative, budgetary, and electoral). Many modern scholars still underline that the Constitution of 1918 was mainly political and ideological, as it rather enshrined a new kind, and the target function, of government and imposed the ideology of the Bolshevist party in the form of the basic law (Brzezinski, 1993, p.673). The first Soviet Russian Constitution adopted in June 1918 had six sections, 17 chapters and 90 articles. It was based on the following key principles: (1) the unity of power in the form of soviets; (2) the class-based principle of organization of power and administration: the dictatorship of the proletariat and the poorest peasantry; (3) the federal, nationality-based structure of the state; (4) the unity of rights and duties of citizens of the Soviet Republic; (5) the socialist nature of the social structure and the policy of the Soviet power in Russia; and (6) free self-determination of nations, proletarian internationalism and the democratic world of workers. The constitution adopted in 1924 and the constitutions of the Union Republics adopted on its basis in general continued the traditions of constitutionalism established by the first Soviet Constitution of 1918.

Constitutionalism of the victorious socialism expressed in the Soviet Constitution of 1936 is also built on the class-based principle of law as an expression of the will of the ruling class. Ideological constitutionality of that period is based on the idea of abolishing the exploiting classes and expanding the social foundation of the power as an alliance between the working class and the peasantry, strengthening the position of the Communist Party and denying political pluralism. In contrast to the previous period of constitutional development, the constitutionalism of the victorious socialism affirms the universal and equal suffrage, emphasizes the unity of the social and economic rights secured by the Constitution, and does not recognize any bourgeois political rights. In addition, it affirms the conditional nature of the idea of withering away of the state under communism and reinforcement of the foundations of the socialist state.

Up until the early 1960s, the Soviet constitutionalism was influenced by Stalin's Constitution of 1936 and its main characteristics given by Stalin in his report "On the Draft Constitution of the USSR in 1936" (Stalin, 1939, pp.507-534). The denunciation of the cult of Stalin in 1956 along with further steps to eliminate recessions of Stalinism gave rise to the idea of drafting a new constitution that would be based on the idea of socialist legality and law. This resulted in the development of the foundations of "socialist constitutionalism." Notably, before the early 1960s, the term "socialist 
constitutionalism" was actually identified with the concept of "constitutional law" and was not developed as an independent phenomenon (Topornin, 1981, p.48). In April 1962, it was decided to draft a new Constitution of the USSR and the Constitutional Commission was established. Although worked on rigorously, the new constitution was not adopted in 1967 as planned due to both domestic and international constraints. It was only in 1977 that a new constitution was adopted to lay down the constitutional principles of developed socialism. The new Soviet constitutionalism adopted the general ideological basis of the previous constitutions, but modified a few fundamental ideas of the constitutional order. First of all, this involved abandoning the idea of the dictatorship of the proletariat and replacing it with the idea of the state of the whole people. Although underlining the class-based nature of the state of the whole people, it was rather an assertion of the continuity of the development than an emphasis on the outlook for activity. The constitution enshrined the leading role of the Communist Party that, according to the ideology of Soviet constitutionalism, has become an important principle of the political system, as well as the state of the whole people and the Soviet people as a new historical community. It asserts the principle of "democratic centralism" as the basis for building and operation of the state of the whole people. The constitutionalism of the late Soviet regime demonstrated some softening of the original principles, however it did not get rid of obvious contradictions in the interpretation of the balance between law and politics. In its socialist version, the idea of the rule of law was distorted by the monopoly of a single political force that was actually substituted for the state power.

\subsection{Constitutional Ideas of the Human Rights Movement in the USSR}

In the USSR, the human rights movement emerged in the forefront of perestroika and glasnost, which were in many respects driven by the so-called "Khrushchev Thaw". The human rights movement is divided into a few different stages: the infancy (19651972); the crisis and broad international recognition (1973-1975); and the Helsinki period (1976-1985). The history of the human rights movement is usually counted from the demonstration that took place in Pushkin Square in Moscow on December 5 , 1965, and the trial against Russian writers Sinyavsky and Daniel (1966) who published the book "Progulki s Pushkinym" [Walks with Pushkin] in the West in 1965 and were charged with anti-Soviet agitation and propaganda. The most famous event in the history of the human rights movement is the trial of 21 members of the All-Russian Social-Christian Union for the Liberation of the People (February - December 1967) and the publication of the bulletin Khronika Tekushchikh Sobytiy [The Chronicle of Current Events] (Moscow, 1968-1983, compiled by N.E. Gorbanevskaya et. al). Important events during the infancy of the human rights movement include a demonstration 
in Red Square against the invasion of Czechoslovakia by the Warsaw Pact (1968), and the establishment of the Committee on Human Rights in the USSR (1970).

The Helsinki period was marked by activities related to implementing the requirements of the Final Act of the Helsinki Conference on Security and Cooperation in Europe (1975) which provided for the respect of civil, political and personal human rights. This resulted in the establishment of the Moscow Helsinki Group and similar groups in Ukraine, Lithuania, Armenia and other republics to supervise the implementation of these provisions in the USSR. In late 1979, the human rights movement launched a campaign against the Soviet invasion of Afghanistan. The human rights movement involved a few hundred or perhaps a few thousand people.

The ideology of the human rights movement was reflected in a number of publications, such as The Reflections on Progress, Peaceful Coexistence and Intellectual Freedom, by Andrei Sakharov, Live Not By Lies and The Letter to the Soviet Leaders, by Alexander Solzhenitsyn, and a collection of articles entitled "From Under the Rubble” contributed by Mikhail Agursky, Evgeny Barabanov, Vadim Borisov, Mikhail Polivanov, Feliks Svetov, Alexander Solzhenitsyn, and Igor Shafarevich. Their political views were in many respects driven by the radical denial of the values of socialism. Igor Shafarevich wrote: "Economic and social demands of socialism are means for achieving its main goal being the destruction of individuality" (Shafarevich, 1992, p.50). The authors put a great deal of focus on the history of Russia, the Russian national consciousness and self-consciousness of the Russian intelligentsia. They often cited pre-revolutionary Russian thinkers, such as Sergei Bulgakov, Alexander Herzen and Fyodor Dostoevsky, as well as famous publications "Vekhi" and "Smena Vekh.” The human rights movement was not ideologically homogeneous, bringing together various currents, including civil movements advocating for human rights with legitimate means within the framework of the Constitution, religious movements (Adventists, Pentecostals, Orthodox Pochvenniki (from pochva, meaning soil), and national movements.

In general, the importance of the human rights movement is determined by the development of values of civil society and true democracy, human rights, and the formation of public opinion. These values have been an important prerequisite for the subsequent changes in the USSR. The liberal conception of natural human rights was in line with the individualistic outlook of the Soviet intelligentsia, but it was not consistent with the Marxist ideology that ontologically denies the idea of inalienable human rights. The dissemination of the value of human rights in the Soviet society has significantly contributed to the subsequent radical social and spiritual changes.

These ideas were in many respects associated with the development of constitutional awareness in the USSR. In some cases, the human rights movement proclaimed the need to observe some important provisions of the Soviet Constitution of 1977, in particular on publicity, the rule of the people, and the right of nations to selfdetermination. What was meant here is that the constitutional provisions should be brought into line with the social realities of the time. This, in itself, caused a conflict 
between the regime and the intelligentsia. In addition, the human rights movement put forward concepts that were beyond its scope (such as private property).

This largely manifested itself in the human rights activities of Andrei, a 1975 recipient of the Nobel Peace Prize and the People's Deputy of the USSR. In 1966-1967, he started his human rights activities and issued his first addresses for the protection of political and civil rights of the Soviet people. In 1968, Sakharov published his article entitled "The Reflections on Progress, Peaceful Coexistence and Intellectual Freedom." The main idea is that mankind is close to a critical point in its history, facing the danger of thermonuclear destruction, environmental poisoning, hunger and uncontrolled population explosion. These dangers are enhanced by the division of the world and the opposition between the socialist and capitalist camps.

The ideological starting point of Sakharov's liberal position is in line with the tradition of Western liberalism: to start with the anthropological premise of freedom and autonomy of an individual and the priority of their inalienable rights. All the subsequent social characteristics and definitions of society and progress (in the technical, economic and socio-political senses) derive from this basic foundation. However, it is not economic or social, but civil and political human rights that are most important, enabling an individual to take a proactive approach to the outside world. In his Nobel acceptance speech Sakharov said, "I am convinced that international trust, mutual understanding, disarmament and international security are inconceivable without an open society with freedom of information, freedom of conscience, the right to publish, the right to travel and choose the country one wishes to live in. I am also convinced that freedom of conscience, together with other civic rights, provide both the basis for scientific progress and a guarantee against its misuse to harm mankind, as well as the basis for economic and social progress. They also constitute a political guarantee that makes the effective defence of social rights possible. In addition, I will defend the thesis of the primary and decisive significance of civil and political rights in shaping the destiny of mankind" (Sakharov, 1990, p.50).

Already early speeches and articles of Andrei Sakharov showed the main thrust of his ideas: to defend social, economic, political and cultural human rights in terms of morality. He criticized the lack of spirituality in Soviet society which was suppressed by state and party authoritarianism and bureaucracy. Criticizing the bureaucratic system of the Soviet state, he wrote: "The bureaucracy is far from self-sacrificing. Concealing the realities behind demagogic slogans, our officials make a mockery of social justice in housing, in health care (most people, for example, have no possibility of getting up-to-date medicines), in the quality of education, etc. The salaries of many workers, and especially those of rank-and-file intellectuals, have been artificially reduced, in effect imposing a hidden tax that weighs most heavily on the lowest paid. The great majority of pensions are shamefully inadequate. At the same time, elite groups enjoy enormous, unjust privileges" (Sakharov, 1990, p.77). Sakharov believed that the poorest should be compensated for the increased rent, higher prices for food and other expenses. 
He called for a true democratization of society, for free and fair elections, for the transfer of power to the Soviets, and for the exclusion of the Communist Party from the political system. Sakharov's proposals could make the USSR a civilized democratic and rule-of-law state of West European type.

In this connection, "the enormous development" of various forms of corruption in the country, giving rise to mafia groups allied with the party and state apparatus, was seen by him as a crucial problem. When offering means to deal with the Soviet political system, Sakharov paid special attention to glasnost. According to him, "Glasnost ought to create a new moral climate in the country...People should know the truth and be able to express their thoughts freely. Corrupting lies, silence, and hypocrisy should be banished from our lives forever" (Sakharov, 1990, p.82). Openness of society means monitoring by society of key government decisions, freedom of opinion, freedom to receive and impart information, and freedom to choose one's country of residence and one's domicile within that country in accordance with the Universal Declaration of Human Rights and the Covenants of Human Rights adopted by the United Nations.

According to Sakharov, the future social and political system of the USSR should be a mixed (public/private) economy, combining as much as possible flexibility, freedoms, social achievements and regulation: "It is necessary to create an economic and legal environment, which encourages initiative, a flexible response to the economic situation, technical innovation, and excellent individual work without any impediments or restrictions imposed by ideological dogma” (Sakharov, 1990, p.83). Cooperatives, family and collective contractors were expected to play an important role in the economy. Sakharov put forward the idea of the convergence of capitalism and socialism that he believed would reduce the military and political tensions in the world. The aim of perestroika was a global and comprehensive disarmament and a balanced reduction of conventional and nuclear weapons up to the total destruction. "To retreat from the brink of global catastrophe, to preserve civilization and life itself on our planet, are necessary priorities... I am convinced that this can come about only as a result of profound geopolitical changes leading toward convergence of the capitalist and socialist systems, an open society, and greater equality for all races and peoples, not only juridical, but also economic, cultural and social equality. Mankind needs a new thinking!”, Sakharov wrote (Sakharov, 1990, p.93). The establishment of a new system involves enhancing international trust, the protection of human rights, law and freedom, social progress and democratization.

Sakharov proposed to implement the following principles of the rule of law: "Freedom of speech and conscience; the possibility for private citizens and public organizations to contest before an independent tribunal the acts and decisions of all officials and government agencies; due process in trial and investigatory procedure (access to defence counsel from the very beginning of a criminal investigation; trial by jury; transfer of jurisdiction over criminal investigations from the Procurator's office, which should be solely concerned with faithful execution of the Laws" (Sakharov, 
1990, p.116). In the context of these proposals, he called for the humanization of the penal system in the USSR, and in particular, for the abolition of the death penalty.

Of particular interest are the measures proposed by Sakharov for dealing with ethnic problems in the USSR. He found it possible and necessary to create a new, national-constitutional system based on horizontal federalism: "This system would grant equal political, juridical, and economic rights to all existing national subdivisions regardless of their size or current status, maintaining the present borders... Persons of different nationalities living together in one Republic should enjoy equal political, cultural and social rights in law and in practice.... Any infringement of freedom of conscience is impermissible" (Sakharov, 1990, p.115). The principles laid down by Sakharov were to form a basis for a society with the synthesized values of social justice and human rights.

The principles proposed by Sakharov were largely implemented in the Constitution of the Russian Federation of 1993, which served as a basis to draft a number of laws building new institutions of the rule-of-law state, such as a multiparty system, democracy, separation of powers, local self-government, entrepreneurship and others.

The ideology of constitutional rule of law was reflected in the concept and activities of Sergei Alekseev. At the turn of the 1980-90s, he served as Chairman of the Committee on Legislation, Legality, Law and Order of the USSR Supreme Soviet and the Chairman of the Constitutional Supervision Committee of the USSR. Alekseev is rightfully considered as one of the main drafters of the current Constitution of the Russian Federation of 1993, along with Anatoly Sobchak and the contribution from Yuri Kalmykov and Stanislav Khokhlov. They developed an alternative to the official draft of the Constitution that included a fundamental section on natural human rights and freedoms. As interpreted by Alekseev, the concept of natural law is understood as "requirements and ideals driven by the natural and socially natural environment that are refracted through the sense of justice and cultural codes to take a legal shape and as such serve as legal requirements and prototypes of legal norms - the norms of positive law" (Alekseev, 1998, p.26). An advantage of natural law is that it performs a methodological function in relation to positive law, which "translates urgent social demands into norms."

However, Alekseev believes that requirements of natural law also have negative aspects that are expressed in morals, customs, religious and other rather vague ideological positions. Therefore, these requirements are often understood in an arbitrary way, "in line with ideas and ideological attitudes of people", while violence and arbitrary action are sometimes "refined" by references to natural law.

An advantage of positive law is that "as a large entity (a subsystem of society), it acts as a regulator of norms and values in the context of civilization" (Alekseev, 1998, p.30). Positive law ensures that society functions with continuous dynamics, achieving the stable reproduction of the social values, conditions and mechanisms that are reflected in law, including for the preservation and establishment of the limits 
of freedom in people's behavior. Alekseev believed that building a rule-of-law state in Russia requires that a "culture of law" be in place to take into account the current status of the country's legal development and to be developed in accordance with "the positive legal realities of the past (the values of the Roman-Germanic (mainly Germanic) type - this was the path Russia firmly took and began to develop in the 18th-19th centuries)" (Alekseev, 2001, p.152).

In general, we can see that the ideas of constitutionalism were consistently developed in the framework of the human rights movement in post-Soviet Russia.

\subsection{Constitutionalism in Today’s Russia}

The current Russian constitution adopted by popular vote in December, 1993 is the product of an axiological and social compromise that was the result of a longer constitutional crisis than the events of October, 1993 (Sharlet, 1993). The origin of the compromise lies in the problem of search for a combination of individual freedom and competence of the state, the people and the power, spontaneous self-organization of society and the order, which is typical of Russian constitutionalism. Developed during an acute conflict between the two branches of power, representative and executive (according to another interpretation: old Soviet and new democratic forces), the constitution proclaims liberal values of natural rights and freedoms of man and citizen and establishes the doctrine of the rule of law, separation of powers, democracy and civil society. The liberal values enshrined in the constitution also include cultural pluralism of society, the freedom of choice in politics, economics and spiritual life, and the protection of privacy and private property. An important achievement of constitutional process is the creation of the Constitutional Court. Institutional presence of the Constitutional Court in Russia is a sign of development of constitutionalism, although its role in Russia is estimated differently (Brzezinski, 1993; Scheppele, 2003).

In addition, the Russian Constitution lays down the standards of a social state and expresses the ideals of social justice. It preserves the rights to work, housing and social security, which emphasizes its relationship with the social philosophy of law and social law

Finally, the current Constitution has elements of the conservative philosophy of preserving the unity and integrity of the strong Russian state, while asserting the principle of federalism in its structure. Other conservative provisions include those that take into account specific features of the Russian social and spiritual culture located in the expression of a strong presidency (Fogelklou, 2003).

According to one of the drafters of the current Russian Constitution, Sergei Shakhrai, it is conceptually based on three main ideas. First, the Constitution is able to provide an ideological basis for public consent on the basis of ideas and principles that are equally important to all individuals regardless of their political views. Second, it is procedural in nature and as such applicable in the context of 
a conflict between different branches of power or between the federal center and a region. Third, the Constitution has an organizational aspect, which allowed to use it as a general basis for social transformations in the country (Shakhrai, 2013, pp.15-16). Thus, the constitutional outlook affirmed the practical nature of the constitution as a tool for legal and socio-political transformations. In contrast to the Soviet constitutions, which subordinated law to politics, the new Russian constitutionalism is based on the priority of law and its ability to serve as a "core of crystallization of the order" (Shakhrai, 2013, p.14).

All this means that the current Russian Constitution is somewhat eclectic in value terms, which makes it flexible in selecting a possible option of the development of social relations. In general, the modern philosophy of law provides conditions within the framework of state constitutionalism to combine activities of a free and socially responsible individual and an endurable public order in Russia. In this philosophy, constitutionalism is not only of the liberal-innovative nature, but also has a conservative sense closely related to the strengthening of the constitutional traditionalism. The ideology of conservative constitutionalism (or constitutional conservatism) aims at strengthening the constitutional nature of the country - the struggle for constitutionalism. This task involves maintaining social peace, providing security of the state and taking into account public interests. Constitutionalism is seeking for a form of protection of human rights that would not undermine the security of the state. Individual rights can only be restricted by law and only if they are abused. Based on this, it seems to be important to preserve the bases of the constitution that will enable us to take into account innovations that arise in society, while fighting for the constitution. Tolerant co-existence is the wisest constitutional position. As emphasized by the well-known Russian legal theorist and currently the Chairman of the Constitutional Court of the Russian Federation Vladimir Zor'kin, "our ideal is to connect the power and freedom on the basis of law as the only measure of freedom. It is only possible to achieve this by combining liberal measures and strong power. This is what conservative legal modernization is truly about...The main thing for us today is by all means not to allow the opposition between the individual and the state. It should be not 'either the state or the individual', but 'both the state and the individual'. This is the meaning of the Russian Constitution which is guarded by the Constitutional Court" (Zor'kin, 2013, p.30).

Important in this context is the discussion of an "economic constitution" (Zor'kin, Lazarev, 2010, p.26), which demonstrates the possibility to make the constitution more specific as the fundamental law as applied to the development of the most important sphere of society. This practice should be extended by considering not only the economy, but also politics, culture and morality. Theoretically, it also seems to be important to analyze the moral foundations of the constitutional process and develop the ethics of constitutionalism, which is associated with the moral positions of the actors of the constitutional process - judges of the Constitutional Court and their moral responsibility to society for decisions they make. 
All this requires that a culture of constitutionalism be gradually developed and the constitutional consciousness be established in the public consciousness. In this context, it is relevant to cite Vladimir Geriye: "In this respect, the Russian public opinion has never played such an important role, nor has it ever had such a great responsibility. The fate of the Russian constitution, the fruit that it can yield, and thus the future of the country depend on what will be the public opinion about the current constitution in the first instance" (Geriye, 2008, 147). These words are in many respects relevant today. The constitutional process involves the gradual and steady improvement of the political system by enriching the enactment practices, building new political institutions, and providing the constitutional awareness of the society. At the same time, the constitutional process will serve as a restraint to prevent the authorities from making hasty, ill-considered political decisions and from using dogmatic social standards that have lost their relevance and vitality.

\section{Bibliography}

Alekseev, S. S. (1998). Filosofiya prava [Philosophy of law]. Moscow: Norma.

Alekseev, S. S. (2001). Taina prava [Mystery of law]. Moscow: Norma.

Bakunin, M. A. (1989). Filosofiya, sotsiologiya, politika [Philosophy, sociology, politics]. Moscow: Pravda.

Balmuth, D. (2000). “The Russian Bulletin”, 1863-1917: A Liberal Voice in Tsarist Russia. New York: Peter Lang Publishing Inc.

Basil, J. (2009). Problems of state and church in the Russian Federation: Three points of view. Journal of Church and State, 51(2).

Berkhin, I. B. (1970). Ekonomicheskaya politika sovetskogo gosudarstva v pervye gody sovetskoi vlasti [The economic policy of the Soviet state in the first years of Soviet power]. Moscow: Nauka.

Bolingbroke, H. S. J. (1809). A dissertation upon parties. In The Works of Late Right Honourable Henry St. John, Lord Viscount Bolingbroke. Vol. III. London: Luke Hansaid and Sons.

Brecht, A. (1937). The new Russian constitution. Social Research, 4(2).

Brzezinski, M. (1993). Toward 'constitutionalism' in Russia: The Russian Constitutional Court.” International and Comparative Law Quarterly, 42(3).

Bukharin, N. (1924). O likvidatorstve nashikh dnei [On this day liquidationism]. Bolshevik, 2.

Chicherin, B. N. (1998). Filosofiya prava [Philosophy of law]. St. Petersburg: Nauka.

Clark, W. (1998). Presidential power and democratic stability under the Russian constitution: A comparative analysis. Presidential Studies Quarterly, 28(3).

Dorosh, H. (1944). Russian constitutionalism. New York: Exposition Press.

Enticott, P. (2016). The Russian liberals and the revolution of 1905. London, New York: Routledge.

Fisher, G. (1958). Russian liberalism. New York: Harvard University Press.

Flere, S., Lavrič, M., and Djordjevič, D. B. (2016). Religious references in the constitutions of European post-communist countries and ethno-symbolism. Journal of Church and State, 0(0).

Fogelklou, A. (2003). Constitutionalism and the presidency in the Russian Federation. International Sociology, 18(1).

Fröhlich, K. (1981). The Emergence of Russian constitutionalism, 1900-1904. Hague, Boston, London: Martinus Nijhoff.

Galai, S. (1974). Early Russian constitutionalism, "Vol'noe Slovo” and “Zemstvo Union”. A study in deception. Jahrbücher für Geschichte Osteuropas, 22(1). 
Geriye, V. I. (1996). Otkritoe pismo Alexandru Ivanovichu Guchkovu ot professora V. I. Geriye [Open letter to Alexander Ivanovich Guchkov from Professor V. I. Geriye]. In Rossiyskiye liberaly: Kadety i oktyabristy. Compiled by D. B. Pavlov, V. V. Shelokhayev. Moscow: ROSSPEN.

Geriye, V. I. (2008). O konstitutsii i parlamentarizm v Rossii [On constitution and parliamentarianism in Russia]. In Y. S. Pivovarov (Ed.), Rossiyskaya politicheskaya nauka, v 5 tomakh. T. 1: 19-nachalo 20 vekov. Moscow: ROSSPEN.

Gimpelson, E. G. (1973). “Voennyi kommunism”: Politika, praktika, ideologiya [„War Communism“: Politics, practice, ideology]. Moscow: Mysl.

Hamburg, G. M. (1992). Boris Chicherin \& early Russian liberalism. 1828-1866. Stanford, Ca: Stanford University Press.

Henderson, J. (2011). The Constitution of the Russian Federation: A contextual analysis. Oxford: Hart Publishing.

Herzen, A. I. (2012). Russkyi narod i sotsialism. Pismo k I. Michelet [Russian people and socialism. Letter to I. Michelet]. In A. A. Shirinyantz (Ed.), Russkaya sotsialno-politicheskaya mysl. 1850-1860. Khrestomatiya. Moscow: Moscow University Press.

Hosking, G. (1973). The Russian constitutional experiment. Government and Duma, 1907-1914. Cambridge: Cambridge University Press.

Katkov, M. N. (2008). 0 samoderzhavii i konstitutsii [On autocracy and the constitution]. In Y. S. Pivovarov (Ed.), Rossiyskaya politicheskaya nauka, v 5 tomakh. T. 1: 19-nachalo 20 vekov. Moscow: ROSSPEN.

Kavelin, K. D. (1989). Nash umstvenny stroi. Statiyi po filosofii russkoy istorii i kultury [Our mental system. Articles on the philosophy of Russian history and culture]. Moscow: Pravda.

Kavelin, K. D. Razgovor s sotsialistom-revolyutsionerom [Conversation with the Socialist-Revolutionary] (2008). In Y. S. Pivovarov (Ed.), Rossiyskaya politicheskaya nauka, v 5 tomakh. T. 1: 19-nachalo 20 vekov. Moscow: ROSSPEN.

Kravets, I. A. (2005). Rossiyskiy konstitutsionalism: problem stanovleniya, razvitiya i osushestvleniya. Moscow: Yuriditcheskiy zentr.

Lenin, V. I. (1974). Complete works in 55 volumes, Volume 44. Moscow: Politizdat.

Lunacharsky, A. V., and Pokrovsky, M. N. (1925). Sem' let proletarskoi diktatury [Seven years of proletarian dictatorship]. Moscow: Moskovsky Rabochiy.

Medushevsky A. N. (2015). Mif Kommuny i stanovlenie Sovetskogo gosudarstva (K pereosmysleniyu Konstitutsii RSFSR 1918 goda). Obschestvennie nauki i sovremennost, 4.

Mityukov, M. A. (1996). Zarozhdeniye idei konstitutsionnogo pravosudiya v Rossii (XIX - nachalo XX v.v.) [The origin of constitutional ideas in Russia (XIX - early XX centuries)]. Pravovedeniye, 11.

Ordeshook, P. (1997). Constitutions for new democracies: Reflections of turmoil or agents of stability? Public Choice, 90(1-4), 55-70.

Pashukanis, E. (1924). Obschaya teoriya prava i marksizm (Opyt kritiki osnovnykh yuridicheskikh ponyatiy) [General theory of law and marxism (Experience of critics of basic legal concepts)]. Moscow: Izd. Soc. Akad.

Razumovsky, I. (1926). K vozzreniyam Lenina na gosudarstvo i pravo [By Lenin's views on the state and the law]. Pod Znamenem Marksizma, 1-2.

Ruutu, K. (2010). Future, past and present in Russian constitutional politics: Russian constitutions in a conceptual-historical perspective. Review of Central and East European Law, 35(1).

Sakharov, A. D. (1990). Mir, progress, prava cheloveka [Peace, progress, human rights]. Leningrad: Sovetsky pisatel.

Sanders, D. (1992). Russia in the age of reaction and reform, 1801-1881. London, New York: Routledge.

Scheppele, K. (2003). Constitutional negotiations. Political contexts of juridical activism in post-Soviet Europe. International Sociology, 18(1). 
Schmid, U. (2010). Constitution and narrative: peculiarities or rhetoric and genre in the foundational laws of the USSR and the Russian Federation. Studies in East European Thought, 62(3-4), 431-451.

Shafarevich, I. R. (1992). Sotsializm [Socialism]. In Iz pod glyb. Collected articles. Moscow: Russkaya Kniga.

Shakhrai, S. M. (2013). 0 konstitutsii. Osnovnoi Zakon kak instrument pravovykh i sotsialnopoliticheskikh preobrazovaniy [On the constitution. The Basic Law as a tool for legal and socio-political transformation]. Moscow: Nauka.

Sharlet, R. (1993). Russian constitutional crisis: Law and politics under Yel'tsin. Post-Soviet Affairs, 9(4).

Sharlet, R. (1994). The prospect for federalism in Russian constitutional politics. Publius: The Journal of Federalism, 24(2).

Speransky, M. M. (2002). Rukovodstvo k poznaniyu zakonov. In I. D. Osipova (Ed.), [Guide to the knowledge of the laws]. St. Petersburg: Nauka.

Stalin, I. V. (1939). Voprosy leninizma [Questions of Leninism]. Moscow: Gospolitizdat.

Struve, P. B. (1997). PATRIOTICA. Politika, kultura, religiya, sotsializm [PATRIOTICA. Politics, culture, religion, socialism]. Moscow: Respublika.

Topornin, B. N. (Ed.) (1981). Teoreticheskiye osnovy sovetskoi konstitutsii [Theoretical basis of the Soviet constitution]. Moscow: Nauka.

Unger, A. (1981). Constitutional development in the USSR. A guide to the Soviet constitutions. London: Methuen \& Co. Ltd.

Walicki, A. (1992). Legal philosophiers of Russian liberalism. Notre Dame: University of Notre Dame Press.

Weber, M. (1995). Russia's transition to pseudo-constitutionalism. In: G. Wells \& P. Baehr (Eds.), Weber, M. The Russian revolutions. Oxford: Polity Press.

Zor'kin, V. D. (2013). Pravo v usloviyakh globalnykh peremen [Law in the face of global change]. Moscow. Norma.

Zor’kin, V. D., Lazarev, L. V. (Eds.) (2010). Kommentarii k Konstitutsii Rossiyskoy Federatsii [Commentary on the Constitution of the Russian Federation]. Moscow: Eksmo. 


\section{Theoretical Problems in the Preamble to the 1997 Polish Constitution in the Perspective of History of Political Thought}

Numerous questions of a general nature appear with regard to the text of the preamble to the Constitution of the Republic of Poland adopted in 1997. They are the outcome of the search, undertaken not only in Poland but also in many other states for a way to incorporate the main solutions worked out by the so-called modern political thought. My intention is not to discuss the multitudinous political declarations inscribed into the Polish Constitution of March 1921 and to prove that in the constitution of the end of the $20^{\text {th }}$ century there are even more telling statements than in the basic law from the past. My aim is to formulate some observations concerning the roots of the provisions which occur in the constitution in force and are set in the various traditions of political thought. For even now one can accept the thesis that the Polish constitution of the second millennium draws from various traditions of political thought, not only from the liberal and the democratic, but also from the socialist and even the conservative traditions; moreover, it also draws from the republican tradition, the relationship of which, with the liberal and conservative traditions, remains one of the most fascinating research problems undertaken today, mainly by the representatives of the "School of Cambridge." Another result of this thesis would be that talking of one axiology, based on a single "normative vision", possibly rooted in a single "way of political thinking”, is problematic. It seems that here we encounter a "complex axiology", drawing from several traditions of political thinking based on various philosophical concepts, especially on the various concepts of man.

Oddly, the introductory text for the Polish Constitution of 1997 contains no reference to the Polish State, a key reference for the Polish Constitution of 1935, which set the basis for the functioning of the Polish authorities in exile during World War II and up until 1991. The first sentence of the preamble points out the possibility of sovereign and democratic determination ${ }^{2}$ of the fate of the "Homeland," regained in 1989, but there is no mention of a similar possibility of determining the fate of the Polish State. It seems that the authors of the Constitution were acquainted with both these terms; however, they were thinking more in terms of a "community" than of an "institution" and this is why they decided to use the first term. At least one component appears to justify this statement. In the following fragments of the text it is stated that the "Polish Nation" is created by all citizens of the Republic and that Poland represents

1 The Jagiellonian University in Kraków.

2 All the fragments of the 1997 Constitution of the Republic of Poland quoted in the article are taken from: http://www.sejm.gov.pl/prawo/konst/angielski/kon1.htm (access: 12.02.2016). 
the "common good." If these components are to confirm the statement formulated above, it is necessary to assume that the "Homeland" and the "Polish State" are a common good and that both these categories need to be related to one more category: "Poland."

However, this thesis seems problematic since the term "Homeland" in the Polish tradition is usually associated with land as well as with the cultural traditions characteristic of the "ethnic Poles" and of the citizens coming from beyond this ethnic community. Therefore, if the aim was to depict the category of "Polish Nation" understood as a "political community" rather than an "ethnic community," then the term "Homeland" should not have been associated only with ethnic nation but rather with the community of citizens, regardless of their ethnic roots. "Civic virtue" should be linked to the relationship between an individual and the state understood as an instance of a political and legal value; therefore, it could easily be associated with the Polish State. However, this leads to a fundamental debate, which is today especially intense in several parts of the world, often cast as a central dispute between liberals and republicans, those who regardless of the ethnic or ethnic and cultural roots place the "individual" first, and those who expect the individual to be "rooted" in a group.

This is the reason why, as in the case of presenting the concepts of "liberal culturalism," the liberals challenge the relationship between that which is individual, and that which is collective; the issues of the protection of the individual against any oppression of the ethnic and cultural group in which that individual is rooted, and at the same time also of the protection of the group identities perceived as prominent in relation to the individual identities. It also turns out that republicans pay less attention to the individual and more to their "civil status," their political relationship with the state or, as they sometimes say, the political community. They emphasize not so much the individuality of a man but his civil value; and not so much the anteriority of an individual in relation to every group, in fact created by individuals, but the rooting of an individual in a group, understood not as an ethnic or ethnic and cultural but as a political group. It appears that the authors of the Polish Constitution of 1997 are involved in this perhaps inconclusive debate.

It seems that, as liberals, they emphasize the anteriority of the individual in relation to all communities (especially in the concluding fragment to the preamble which highlights the importance of sustaining the inherent dignity of the individual and his or her right to freedom), but also, as republicans, they place the individual within the "Polish Nation," note the "perpetual guarantee" not for the "individual rights" or "human rights," but the "civil rights" (however, in this case no relation to a state as the "moment" constituting all rights is indicated).

The statement that the authors of the Polish Constitution draw from various traditions, which at present remain in a state of serious tension because of the ongoing dispute about the influence of the "Atlantic republican tradition" in the West, does not exhaust the issues appearing in the preamble. On the one hand, as already stated, the "Polish Nation," which includes all the citizens of the Republic of Poland regardless 
of their ethnic and cultural roots, is spoken of, therefore, in a probable association with the Polish State (presumably to champion civic virtue). On the other hand, not only is it said that the "Polish Nation" is "culture rooted in the Christian heritage of the Nation and the universal values," but its bond with the Poles remaining outside the territory of the Polish State is also emphasized: “...we, the Polish Nation - all citizens of the Republic... bound in a community with our compatriots dispersed throughout the world."

These two fragments of the preamble referring to the above "other hand" have neither a liberal nor a republican value. Instead, they are directed neither towards an individual as such, regardless of their community roots, nor towards a political community to which the individual belongs and, therefore, co-creates the "Polish Nation" as a "civil nation" of a political rather than ethnic or cultural status. Both fragments describe the Poles as an "ethnic nation" which is constituted by their common culture rooted both in the Christian heritage and in perceived universal values.

This is yet another proposition which can be found in the preamble, leading towards a group of issues justifying the thesis about the theoretical multiplicity of the 1997 Constitution. However, it turns out that the provision about the rootedness of culture in the "Christian heritage" and "universal values" not only problematizes the two approaches pointed out earlier (i.e., liberal versus republican), but it can also suggest a certain kind of separability of the already mentioned sources. This suggestion is intensified by a fragment appearing before it in the preamble, in the provision which pronounces that the "Polish Nation" is created by "all citizens of the Republic, both those who believe in God as the source of truth, justice, good and beauty as well as those not sharing such faith but respecting those universal values as arising from other sources." Here, for the first time, the "universal values" are mentioned (which are supposed to be truth, justice, good and beauty); however, they are drawn either from God or from "other sources.” A problem of substantial philosophical standing, resulting from the thesis about the "establishing," most probably by God, of that which was called the "universal values," about their appearing as a result of God's will, can be omitted here, along with the inspiring discussion whether opting for the voluntaristic solution is a justifiable (and the only possible) approach towards the universal values as being constituted by God and not as the result of God's constitution but as the result of their "everlasting existence," as perceived by those who do not believe in God or who at least do not draw the "universal values" from His will. Nevertheless, while omitting these important issues, we should also realize that their complexity, and especially their "duality," can affect understanding of the provision about the culture rooted in Christian heritage (on the one hand) and in universal values (on the other).

Whether this kind of reading affects the ethnic and cultural rootedness of Poles, is found among other citizens of the Republic of Poland, presents another impotant issue, perhaps also useful for understanding the complexity of the relationships between the Poles, who create an ethnic and cultural group, and those (on the one 
hand) who, while being Poles, having the same culture, remain outside the country, and those (on the other hand), with whom the Poles co-create the political "Polish Nation" within the country, as citizens of the same state (named in the preamble "Rzeczpospolita Polska" [Republic of Poland]). The Poles living in the country are bound by the commonality of the roots with the first group (having common ethnic and cultural roots, though resulting from two potentially different sources), emphasized not only by the reference to the "best traditions of the First and the Second Republic" made in the preamble, but also by the commitment formulated there, to bequeath to "future generations" all "that is valuable from our over one thousand years' heritage" (referring, most probably, mainly to cultural and political achievements).

The second group, comprised of the citizens who do not have roots in the Polish cultural heritage, are bound only by the civil union: it is with them, with the members of this group and not with the members of the previous group, that they, as citizens, co-create the "Polish Nation" of a political value. The members of the "Polish Nation" who remain in the country, who have Polish citizenship regardless of their ethnic and cultural roots, who may or may not believe in God, should, in any case, be grateful to their ancestors for their efforts, struggle and culture and at the same time they should also receive equal treatment when it comes to rights and obligations towards the common good.

The last fragment raises another concern. All the issues already pointed out, which prove the multiplicity of approaches present in the 1997 Constitution of the Republic of Poland, should be complemented with remarks about the equality of rights and obligations of all citizens towards the common good - Poland, and also about the role of the basic law, included in this part of the Constitution. According to the preamble, the "Polish Nation" ("civil") establishes the Constitution as the "as the basic law for the State, based on respect for freedom and justice, cooperation between the public powers [and not on the division of them], social dialogue as well as on the principle of subsidiarity in the strengthening the powers of citizens and their communities." Firstly, it is worth noting that the "Polish Nation" in this fragment becomes in a certain way subjectivized, since it is its will (a "collective will"?) that becomes the source of the basic law. The basic law exists to determine the "basic laws for the state." Would this "Nation," therefore, be primary in relation to the "state"? Would the will of this Nation be establishing that which becomes a collection of "basic laws" for (perhaps) the state constituted in this manner with regard to its "legal dimension"? Finally, does the state exist before this establishment as a "structure" or an "institution" only in the "plan of factuality," and through this establishment some extra, "normative" dimension is bestowed on it?

There is no need to refer to the concept of "constitution of a well-ordered society" proposed by Rawls to notice the priority of the "Polish Nation" conceptualized in this way (once again: perceived as a "civil nation") towards the state. It is the subjectivized "Polish Nation" (as a collection of citizens, and not as a community bound with a common culture, even if it were to result from a "two-source origin") that is to posses 
the will with the use of which it can establish the Constitution as the "laws basic for the state." In this approach, the "Polish Nation" is prior towards the state. And here a problem arises which needs additional attention: if a citizen appears only as a member of the state, it is impossible to talk about citizenship as prior to the state; the theoretical issue here is of a serious nature and caused serious controversy in the past, which related to understanding the state as a structure embodied by a monarch associated not with his subjects but in the first place with God, and constituting the "basic laws" for the subjects, or as "something" with is "embodied" by the "people" who establish the basic laws for themselves (and also for the state associated with them). Regardless of the complexity of this issue, it should be stressed that in the preamble to the Constitution a question is introduced that should be emphasized once again: if this solution, which seems to be well grounded (even though problematic), about the priority of the "Polish Nation" with relation to the state would be accepted, or in the case of accepting the thesis about the simultaneous existence of the "Polish Nation" and the state, there remains the matter of the absence of the basic laws before the legal judgment pronounced by the "Polish Nation." This subject, therefore, would operate in a certain "normative vacuum" and only its judgment would provide access to the basic laws. Moreover, even if the state would act on the basis of the "basic laws" established for it by the "Polish Nation," the legal activity of the "Nation" would be based not on the law, not even on the "basic laws," but on the "fact" which would not be preceded or regulated even by the "basic laws." This solution is typical for the contemporaries, as well as for several modern concepts; however, it is actually specific to these concepts which emphasize the role of "factuality" as the foothold or even the source of the "normative sphere" (with an additional problem: does the so-called naturalistic fallacy, known to ethicists, occur here?)

Referring to the fragment quoted above, which states that the "Polish Nation" establishes the Constitution as the "basic laws for the state,", it is worth noting one more issue: the fragment mentions the "basic laws" established not for the individual or the citizen, but for the state, the "laws" which, however, are to be based "on respect" (a highly problematic formula) for both freedom (whose freedom? of the state or of the individuals-citizens?) and justice (what kind of justice? understood in what way? referring to some "normative order" of a higher standard or rather to individual entitlements, rights or freedoms, or perhaps to the mutual obligations of groups and individuals which together make up the so-called "Polish Nation" "understood as civil"?). Furthermore, the "basic laws" established for the state are also to be based on the "cooperation of authorities" and on "public dialogue." They "are to be based," which means that the "cooperation of authorities" and the "public dialogue" are no doubt prior to the provisions which refer to them.

What is more, there is mention about the "the principle of subsidiarity in strengthening the powers of citizens and their communities"; therefore, the "rights of the citizens and their communities" would surely have to be prior towards the provisions which announce the realization of the principle of subsidiarity, for they are to 
"sustain" the "rights" (which probably already exist) of both the citizens and their communities. Referring to the latter question one's attention is drawn once again to the interesting debate between the followers of the liberal tradition and the followers of the republican tradition, who have a different understanding of not only the freedom of the individual in relation to the potential freedom of the community cocreated by individuals and their "smaller communities," but also the existence and the juridical value of "rights."

The problem also involves a much more serious theoretical issue concerning the rights of the citizens (and not of individuals, so rather of those who remain in such a relation to the state which justifies "civic virtue," than of those who have not yet entered such a relation) as potentially the first provisions of the Constitution which, after all, crowns (according to some scholars, at least in a declarative or postulative manner) the structure of the state legal system.

This issue is also related to the problem which can be described as follows: it has already been said that in the preamble there is no reference to the state (however, its name: the Republic of Poland appears; the term "state" can be found in the preamble only once, when mentioning the Constitution of the Republic of Poland as the "basic laws for the state"), as well as that in its text there is a reference to the "civil rights" which the "Polish Nation" (while establishing the Constitution "as the basic laws for the state") wishes to guarantee "for all time" thanks to itself (or them). Therefore, the "Polish Nation" is to guarantee the civil rights through the establishment of the Constitution, and not the human rights which are mentioned in the preamble when the confession occurs that "all citizens of the Republic co-creating the Polish Nation are aware of the bitter experiences of the times when fundamental freedoms and human rights were violated in our Homeland". Further, considering that the preamble mentions "universal values" and lists among them truth, justice, good and beauty, it should also be added that it subsequently recalls one of these "values", that is justice, in the fragments which refer to the foundations of the Constitution as the "basic laws for the state"; however, there is no mention of the "truth of the human person" or the good of the single individual or/and group as well as the entire "Nation". Nevertheless, in the concluding fragment of the preamble a statement can be found which draws attention to another highly problematic issue. Indeed, a statement occurs with the value of a postulate addressed to those who apply the Constitution for the good of the Third Republic, while the reference to the good of the "Third Republic" (would that be the "name of the state"?) is accompanied by an indicator according to which the Constitution should be applied paying respect to the inherent dignity of the person, their rights and freedoms, and the obligation of solidarity with others. The respect for these "directional principles" is to constitute the unshakeable foundation of the Republic of Poland, through which its good (the good of the community, perhaps some "subjectivized community"?) becomes tightly connected with honouring these principles, with such an implementation of the constitutional norms which would consider the care for the inherent dignity of the person, their freedoms 
and the obligation of solidarity with others. The good of the state is in this way interpreted from the point of view of the application of constitutional norms according to "directional principles", and not according to the contents of these principles.

It seems apparent that in this way the provisions of the preamble open a discussion about the primary character of constitutional norms towards that which is named the inherent dignity of the person, their freedom and the obligation of solidarity. However, they do not open a similar discussion about the issue of the primary character of these norms towards the civil rights, which are to be "guaranteed for all time." The authors of the Constitution of 1997 most probably assumed that inasmuch as the rights of every citizen are prior towards the constitutional provisions and towards the "basic laws for the state" (could this mean that he or she, together with other citizens, is supposed to be the "primary guardian" of the legislation?), the "human rights do not posses such a value"?

3 There have been some attempts to solve this problem by stating that the notion of human laws (but not citizen laws as the preamble pronounces) needs to be first of all determined on the "philosophical and legal level", defined within the former as the moral imperatives (moral obligations), and it needs to be decided that their source rests in the inherent dignity of the person and refers to shaping the place for an individual in the society and the state, and especially the protection of values of fundamental importance to development and self-realization of an individual. The "human rights" in this approach are associated with the inherent dignity of the person and with the obligations of moral value: such obligations, moral but not legal, are to be the first goal of democratic state which should translate the moral imperatives into the language of legal norms (Prawo konstytucyjne Rzeczypospolitej Polskiej [Constitutional law of the Republic of Poland], Ed. P. Sarnecki, ed. 3, Warszawa 1999, p. 44). This thesis is important in the sense that the democratic legal state is almost a priori obligated (by whom?) to accept the moral imperatives and to grant them a legal shape. The structure of the argument, which seems to correspond with the contents of the Constitution, suggests that firstly there exists some "reality" which has a moral value and constitutes the source of human laws also having moral value, and that the goal of a democratic legal state is to "translate" the "moral imperatives" set in this reality into "legal norms". However, it is worth noting that the existence of such a "moral reality" is not mentioned in the preamble to the Polish Constitution of 1997, unless we decide that it is constituted by the "two-source" culture which perhaps in some way influences the method of constructing (interpreting?) morality and its appropriate imperatives. The preamble also suggests the existence of the civil rights (and not the human rights) which are to be „guaranteed for all time”, that its authors decided that these rights (and not the human rights) would potentially exist in a specific "moral reality" (perhaps also of juridical importance, since the civil rights are to be guaranteed by the Constitution) prior towards the legislative will of the "Polish Nation". We can also stipulate that the research carried out today by the so-called philosophers of politics more and more often leads to the conclusion that each of the individual rights (a human right or a civil right) is established only through the will of a group of subjects including everyone on whom these rights are bestowed. This implies that prior to the "act of bestowing" these rights do not exist, that - and this remark is of a more serious nature - prior towards the decisions of a legislator no "moral reality" exists, there is no sphere anterior towards them out of which the human rights and/or the civil rights could be drawn. Being aware of these stipulations - so important for the constitutional debates carried out in several countries, especially after the end of World War II when the research concerning the "higher normative order" (sometimes associ- 
ated with natural law understood as a set of norms, thus with the set of legal rules and norms) basically became abundant. I will limit myself to an indication that the "translation" of moral norms (understood as imperatives, that is obligations, or principles which are assuredly the basis of these obligations) into the language of legal norms may not take place due to the absence of this "reality" which is supposed to be translated, due to the absence of that which we call the moral imperatives (obligations). This statement is, of course, highly controversial and can be criticized from several points of view (it was also criticized by the author of these words in the text Państwo prawa $z$ perspektywy konserwatywnej filozofii polityki (zarys problematyki) [The legal state in the approach of the conservative philosophy of politics (an outline of the problem)]; [in:] Spory wokót teorii i praktyki państwa prawa [Disputes over the theory and practice of legal state], Ed. G. Ulicka, S. Wronkowska, Warszawa 2011, p. 29-46). It is, however, worth formulating because also the text of the preamble leads towards it, especially in those fragments in which - as it has already been pointed out - the non-homogeneity of the sources of Polish culture and the non-homogeneity of the sources of "universal values" are emphasized, which for some people can be changeable (e.g. when they originate from God's will) and for other people cannot, and which by some can be perceived differently than by others etc. The attempts to prove that there exists one catalogue of "universal values" which is complete, free of contradictions and having the ultimate value are nowadays contested as having a "totalitarian potentiality". As such, this conviction is not generally accepted, which is visible also in the Polish experience. It is also worth raising one more issue which appears often even in the manuals: sometimes it is assumed, just as in the previously mentioned study on the Polish constitutional law, that the analysis of the human rights on the legal level needs to be carried out in relation to the notion of rights ("someone's rights") as a specific type of a legal situation of an individual, that is a situation created by law; the problematic, as previously demonstrated, moral imperatives associated with the inherent dignity of the person on this level become the rights, e.g. they become legal situations created by substantive law and thus by the legal norms. That which was recognized as the "first goal of a democratic legal state" becomes, therefore, realized thanks to the "translation of the moral imperatives into the language of legal norms", thanks to the legislator's will to bestow the legal value on the moral norms while pursuing the above mentioned goal. The rules are a legal situation of an individual based on the assumption that it can demand a specific act from a different subjects (an act or an omission) to its own benefit, whereas on the specific subject rests the legal obligation to realize this act. Therefore, a moral imperative translated into the language of legal norms gives not only an ability to act to the one on whom it is bestowed, but also an obligation which corresponds to the ability, resting on the addressee of the demand claimed by the subject, who may now use not only the moral, but also the legal ability. Indeed, both the moral imperative and the legal rule indicate the existence of two sides of the relationship regulated by them: the party to whom the ability is ascribed, and the party on whom rests the obligation corresponding to that ability. The "able party" demands realization of the obligation (as a "legal duty") from the other party, that is the public authorities. I would like to stress once again that the issue refers to human rights and not the civil rights, and that it is suggested that it is the human rights which are to gain a juridical value, and not the civil rights (to which the pronouncement of the preamble about being "guaranteed for all time" refers). This issue is less problematic while it refers to the obligation of applying the human rights (the earlier "moral imperatives") by the executive powers, for these should act on the basis of the established legal norms and within the limits set by these norms, and at the same time they are to apply the Constitution - according to the postulate included in the preamble - while paying respect to the inherent dignity of the person, his or her right to freedom, the obligation of solidarity with others, thus respecting the principles of the unshakeable foundation of the Republic of Poland, of the Polish State. This issue is far more problematic when one considers the authorities establishing the law, the legislature. For indeed these authorities 
decide the contents of the set of legal rules and norms and determine the contents of conduct of the other authorities of the state, they also shape the set of rights and associate with them the sanction directed against the subjects on whom rests the obligation to respect or to realize the abilities-rights of the eligible individuals. In the case of the lack of realization of this act by the subject on whom rests the "legal obligation" (e.g. public authorities), an individual is granted a legal means which will allow for the enforcement of the obligation, for the ability to enforce the law by an individual is the necessary feature of the rights, as it is stated further in the argumentation. Therefore, the rights protect the ability being at first just a "moral imperative", and by bestowing on it the legal value determines the legal means enabling the eligible subject to enforce the obligation resting on the other party, on the public authorities. This structure "places" the eligible subject against the obligated subject, granting the former with legal means which are to enable the enforcement of the obligations resting on the other party from that party. The problem is that it is the state which is recognized as the obligated party, from which the eligible individual (after transforming his or her moral ability into an ability of the legal value) can claim the realization of an obligation resting on it which corresponds to the ability ("moral imperative"), previously moral, recognized as worthy of legal protection by the state authorities which establish the law. Not going into the discussion regarding one of the most serious problems in the history of modern philosophy of politics, concerning the subject able to reveal the list and the contents of such "moral imperatives", not entering into the discussion about - as some historians of doctrines call it - the "sovereignty" of the individual, the people, the parliament, the head of state or indeed the state itself, I would like to indicate that the existence of the mentioned "imperatives" sets the limits of legislative freedom of the subject establishing the legal norms, no matter who that subject is. At this point, however, occurs a controversial statement which is the result of accepting the analyzed structure: the rights - which is cognate to legal positivists, write the authors of the manual, and similar lines of argument can be found in the majority of books dedicated to contemporary constitutional law - is shaped, and not "passed in the final form", by the legal norm which is to determine the contents of that which first existed as an imperative-moral principle. Therefore, "at the final authority" it is the will of the legislator which decides not only about granting the legal value to the moral imperative-principle, but also about granting it the "legal form". The legislator shaping the contents of the rights is not in fact bound by the contents of the moral imperative-principle, and it is not about discerning it but about granting it a form, about confirming it in its own contents which may be undefined in the imperative itself. It also seems that this imperative possesses "to the end" only a moral value, and not a legal value, since the legal value occurs only in relation to the act of establishing the will of the authority shaping the contents of the law, moreover, shaping it in an imperative manner. The problem encountered here is of a fundamental nature. On the one hand it is about the juridical value of the rights associated so often with the human rights (in spite of the fact that the Constitution announces only the guaranteeing "for all time" of the civil rights), and on the other hand it is about the authorities of the legislator setting the norms of a lower standard with regard to those included in the Constitution. In the latter case it is expected that the legislator will honour the rights granted to each person on the territory of the Polish State (as it is established by Art. 37 Par. 1 of the Constitution of the Republic of Poland) and that it will take into account the article of the Constitution which states not only that The inherent and inalienable dignity of the person shall constitute a source of freedoms and rights of persons and citizens but also that this dignity shall be inviolable and that The respect and protection thereof shall be the obligation of public authorities, including the authorities of the legislature (Art. 30 of the Constitution of the Republic of Poland). More on the subject, see e.g. B. Szlachta, Państwo a obywatel (uwagi o pojmowaniu obywatelstwa i praw $z$ nim zwiazanych) [The state versus the citizen (remarks on understanding citizienship and the laws related to it], [in:] Państwo jako wyzwanie [The state as a challenge], Ed. A. Rzegocki, Kraków 2000, p. 75-103. 
This way of reading, though characterized by the frequent usage of the structure "it seems," problematizes to an even greater extent the issue of the anteriority of a person who is not a citizen before the appearance of the state, or (as in the Constitution) the anteriority of a citizen who becomes a citizen in relation not so much to the already existing state based on some normative structure, but in relation to the state as a certain, specific "pre-normative fact" associated perhaps not with the "structure of power" but with the "community of human subjects" (again: was this the intention of the authors of the Constitution, or where they thinking of some "pre-normative community" treated as the "pre-legal state", and having the ability to establish for itself a "normative structure" and to "transform" into the state based on the "normative structure" established by this community?). With regard to the latter issue, this intensifies the problem concerning the existence of a citizen together with his or her rights which are to be guaranteed through the "basic laws" established by the "Polish Nation" for the state and therefore by the citizens of the Republic of Poland somehow existing before the establishment of the "basic laws for the state". The same can be said for the problem of a citizen's existence as, on the one hand, a co-creator of the "basic laws for the state" and, on the other, the subject of laws "guaranteed" by the organs of the state, due to the realization of the "basic laws for the state" which are to guarantee "for all time" the rights for all citizens, co-established by them.

It therefore becomes apparent that discovered several controversial issues can be found in just the preamble to the Polish Constitution of 1997. These topics may be particularly of interest not only to historians of political thought or philosophers of politics, but also to philosophers of law, or even ethicists. An incomplete series of controversies was described in the text and presented to the Readers more as a set of questions than a set of answers. However, perhaps it is worth posing questions even while reflecting over the texts of a written constitution, if only to be able to search more consciously for the answers to the more detailed questions. 


\section{Index}

Adams, J. 71

Agursky, M. 135

Aksakov, I.S. 128

Alekseev, S. 138, 139

Alexander I 119, 124, 125, 126

Alexander II 124, 125, 127

Alexander Jagiellon 68, 117

Alfonso III 5

Almain, J. 8

Althusius, J. 8

Andrew II 66, 92, 93

Apponyi, A. 90, 101

Aristotle 2, 8, 16, 121, 123

Augustine, St. 4

Averre, D. 57

Azo 6, 7

Bagehot, W. 11, 60

Bahlcke, J. 94

Bailyn, B. 71, 72

Bak, J.M. 66

Bakunin, M. 129

Barabanov, E. 135

Barrès, M. 84

Barry, D. 52

Barthélemy, J. 79

Basil, J. 141

Batthyány, J. 98

Baudson, G. 78

Beaumanoir, P. de 6,7

Beveridge, W.H. 46

Beyme, K. 18

Bismarck, O. von 17, 47, 48, 58

Blair, P. 52

Blank, S. 53, 56

Böckenförde, E.-W. 18, 25, 26

Bocskai, I. 89, 92, 96, 97, 112

Bodin, J. 120

Bolingbroke, H. (St. John) 10, 123

Bolingbroke, H. St. John 10, 123

Borisov, V. 135

Boulainvilliers, H. de 80

Bourdieu, P. 92

Bracton, H. 6, 7, 65

Brandt, P. 15

Brown, A. 54, 55, 56

Bruni, L. 8

Brunner, G. 26
Brzezinski, Z. 124, 133, 139

Bukharin, N. 131

Bulgakov, S. 135

Burke, E. 10, 11, 23, 105

Butterwick, R. 120

Capitant, R. 85

Carlyle, A.J. 7

Casimir III the Great 115, 116

Casimir IV Jagiellon 117

Catherine II 123

Catherine the Great 58

Chernyshevsky, N. 129

Chicherin, B. 127, 128

Childeric 5

Chtopicki, J. 119

Church, W.F. 77, 102

Cicero 2, 8, 121

Clausewitz, C. von 35

Coke, E. 5, 9, 11, 66, 74

Collingwood, R.G. 91

Collinson, P. 70

Conac, G. 80, 81

Concha, G. 90, 101

Coquille, G. 8

Cropsey, J. 50

Czartoryski, A.J. 120

Debré, M. 85

Delsol, C. 77, 86

Descartes, R. 41

Dicey, A.V. 10

Di Fabio, U. 19

Dostoevsky, F. 135

Dreier, H. 29

Ducancel 14

Duez, P. 79

Duguit, L. 79, 81

Dumoulin, C. 9

Dunajewski, J. 120

Edward I 64

Edward III 65, 69

Edward the Confessor 66

Elizabeth I 118

Engel, C. 25

Fedorowicz, J.K. 67

Fenelon, F. 10

Ferry, J. 76, 77

Forsthoff, E. 14, 29

Frederick II 5

Fuller, L. 11, 20

Furet, F. 76, 80, 82 
Gaetanus 8

Gaulle, C. de 75, 76, 78, 83, 84, 85

Gelasius I 4

Gerber, K. 22

Geriye, V. 125, 128, 141

Gissey, R.E. 67

Gorbachev, M. 52, 57

Goslicius, L.G. 114

Gradovsky, A. 126

Gregory VII 5

Grimm, D. 15, 16, 23, 29, 30

Grzybowski, K. 81, 82

Guizot, F. 16

Habermas, J. 39, 40, 59

Hajnik, I. 90, 101

Hauriou, M. 79, 86

Hegel, G.W.F. 25, 26, 35

Heidegger, M. 92

Hendley, K. 53

Hennis, W. 26, 27

Henry de Bracton 6

Henry I 64

Henry III 64, 65

Herzen, A. 129, 135

Heun, W. 15

Hitler, A. 102, 103

Hofmann, H. 15

Honorius III 93

Hooker, R. 9, 11

Hörcher, F. 99, 104

Horthy, M. 91, 102

Huber, E.R. 26, 27

Innocent IV 5

Irnerius 6, 7

Isensee, J. 26, 28

Ivan the Terrible 55

Jadwiga of Poland 116

James, H. 5, 11

James I 5, 11

Jan I Olbracht 117

Jellinek, G. 28, 78, 79

Jogaila 116, 117

John Fortescue 8

John I 66

John of Paris 6

John of Salisbury 5

Joseph II 90, 98

Justinian the Great 4

Kádár, J. 103

Kahn, P. 33, 34, 35, 36, 41, 42, 43
Kant, I. 10, 50, 51, 54

Katkov, M. 128, 129

Kaufmann, E. 27, 28

Kavelin, K. 127

Kecskeméti, K. 99

Kelly, P. 79

Kelsen, H. 12, 19, 22, 54

Khomeini, A. 35

Koetter, M. 49, 54

Kohn, H. 34

Konopczyński, W. 116

Kovalevsky, M. 126, 128

Kronman, A.T. 54

Kultsár, I. 99

Kutrzeba, S. 3

Laband, P. 22

Ladislas I 115

Lake, D. A. 61

Łaski, J. 118

La Tour du Pin, R. de 81

Lenin, V. 131

Leontiev, K.N. 128

Leshkov, V.N. 128

Lewandowska-Malec, I. 69

Locke, J. 10

Loewenstein, K. 29

Lothair 6

Louis I 67, 116, 117

Louis of Anjou 67

Luchaire, F. 75, 80, 81

Lutz, R. 20

Madden, M.R. 63, 67

Mair, J. 8

Maitland, F.W. 65

Malberg, C. de 82,85

Manent, P. 34, 36, 42

Mao Zedong 35

Marcic, R. 16

Marczali, H. 94

Maritain, J. 79, 80

Marsilio of Padua 8

Matz, U. 16

McFaul, M. 57

Mcllwain, C.H. 65

Melhárd, G. 98

Miskolczy, A. 99

Mohl, R. von 51, 54

Mohnhaupt, H. 15

Montesquieu, Ch. de 11, 83, 90, 98, 127

Morabito, M. 23, 78, 80 
Muravyov, N. 124

Muromtsev, S. 126,128

Nagy, I. 100, 103

Napoleon Bonaparte 119

Nicholas II 45

Nikolai I 120

Nikolay II 125

Oakeshott, M. 91

Ordeshook, P. 125

Orfield, L. 66

Orzechowski, S. 3,69

Pashukanis, E. 132

Pestel, P. 51, 124

Péter, L. 89, 90, 93, 96, 98, 99, 100, 101, 105

Peter the Great 58

Piasecki, A. 78, 82

Pietrzyk-Reeves, D. 70, 75, 78

Placidus, J.W. 51

Plato 3, 14, 123

Pokrovsky, M. 131

Polivanov, M. 135

Polybius 3, 8

Preuss, U.K. 19, 28

Putin, V. 53, 54, 55, 56, 57, 58, 59, 61

Radich, N.A. 61

Rady, M. 66, 89, 93, 94, 95

Rawls, J. 39, 147

Reisner, M. 132

Rothwell, H. 64

Rousseau, J.-J. 16, 20, 76, 78, 79, 82, 83

Rufinus 5

Sakharov, A. 135, 136, 137, 138

Šalkauskis, S. 36

Salutati, C. 8

Sancho II 5

Sanders, D. 127

Sarkozy, N. 82

Schieder, T. 15

Schmale, W. 14

Schmid, U. 125

Schmitt, C. 12, 28, 29, 39, 42, 43

Schoen, W. 25

Schulze, H. 17

Séguin, P. 76, 77

Seyssel, C. de 9

Shafarevich, I. 135

Shakhrai, S. 139, 140

Sieyès, E. 16, 83

Sigismundus Augustus 118, 121

Smend, R. 26, 28
Smith, T. 9

Sobchak, A. 138

Sólyom, L. 104, 106, 107

Solzhenitsyn, A. 135

Speransky, M. 124, 126, 127, 130

Starck, C. 19

Starkey, T. 8

Stephan, St. $66,92,117$

Stolleis, M. 16, 20

Stolypin, P.A. 128

Struve, P. 127, 128

Svetov, F. 135

Szekfü, G. 96, 102, 108

Szijártó, I. 90, 97, 98, 99, 109

Szlachta, B. 1, 75, 78

Szymanek, A. 68

Teleki, P. 103

Terre Vermeille, J. de 7

Thomas Aquinas, St. 6,7

Tikhomirov, L.A. 128

Timon, A. 90, 101

Tkachev, P. 129

Tocqueville, A. de 41, 42, 44, 79, 80

Tudósítások, H. 99

Turner, R. 64, 65, 66

Ürményi, J. 98

Uruszczak, W. 70, 118

Valdemar the Victorius 66

Vattel, E. 15

Vladimiri, P. 121

Vorontsov, A. 124

Walicki, A. 143

Weber, M. 50, 53, 54, 59

Werbőczy, S. 89, 90, 92, 94, 95, 96, 110

White, A.B. 65

Wilson, G. 66

Winkler, H.A. 17

Wittgenstein, L. 92

Wtadystaw Jagiełto 67

Yeltsin, B. 54, 55, 58

Zaborowski, S. 70 